National Water-Quality Assessment

\title{
Simulation of Groundwater Flow in the Glacial Aquifer System of Northeastern Wisconsin with Variable Model Complexity
}

Scientific Investigations Report 2017-5010 



\section{Simulation of Groundwater Flow in the Glacial Aquifer System of Northeastern Wisconsin with Variable Model Complexity}

By Paul F. Juckem, Brian R. Clark, and Daniel T. Feinstein

National Water-Quality Assessment

Scientific Investigations Report 2017-5010 


\title{
U.S. Department of the Interior \\ RYAN K. ZINKE, Secretary
}

\section{U.S. Geological Survey William H. Werkheiser, Acting Director}

\author{
U.S. Geological Survey, Reston, Virginia: 2017
}

For more information on the USGS - the Federal source for science about the Earth, its natural and living resources, natural hazards, and the environment-visit https://www.usgs.gov or call 1-888-ASK-USGS.

For an overview of USGS information products, including maps, imagery, and publications,

visit https://store.usgs.gov.

Any use of trade, firm, or product names is for descriptive purposes only and does not imply endorsement by the U.S. Government.

Although this information product, for the most part, is in the public domain, it also may contain copyrighted materials as noted in the text. Permission to reproduce copyrighted items must be secured from the copyright owner.

Suggested citation:

Juckem, P.F., Clark, B.R., and Feinstein, D.T., 2017, Simulation of groundwater flow in the glacial aquifer system of northeastern Wisconsin with variable model complexity: U.S. Geological Survey Scientific Investigations Report 2017-5010, 52 p., https://doi.org/10.3133/sir20175010.

ISSN 2328-0328 (online 


\section{Foreword}

Sustaining the quality of the Nation's water resources and the health of our diverse ecosystems depends on the availability of sound water-resources data and information to develop effective, science-based policies. Effective management of water resources also brings more certainty and efficiency to important economic sectors. Taken together, these actions lead to immediate and long-term economic, social, and environmental benefits that make a difference to the lives of the almost 400 million people projected to live in the United States by 2050.

In 1991, Congress established the National Water-Quality Assessment (NAWQA) to address where, when, why, and how the Nation's water quality has changed, or is likely to change in the future, in response to human activities and natural factors. Since then, NAWQA has been a leading source of scientific data and knowledge used by national, regional, state, and local agencies to develop science-based policies and management strategies to improve and protect water resources used for drinking water, recreation, irrigation, energy development, and ecosystem needs (https://water.usgs.gov/nawqa/applications/). Plans for the third decade of NAWQA (2013-23) address priority water-quality issues and science needs identified by NAWQA stakeholders, such as the Advisory Committee on Water Information and the National Research Council, and are designed to meet increasing challenges related to population growth, increasing needs for clean water, and changing land-use and weather patterns.

Federal, state, and local agencies spend millions of dollars each year to ensure that water pumped from the Nation's aquifers is suitable as a source of drinking water for the millions of Americans that rely on groundwater for daily consumption. Understanding the vulnerability of groundwater to man-made and natural contamination is crucial for anticipating and implementing appropriate land management and water treatment plans to ensure clean drinking water now and into the future. Modeling of groundwater resources provides a basis for understanding and mapping groundwater vulnerability across large areas. This report addresses the question of how complex a model is needed for accurate estimation of groundwater levels and streamflows. The results of this work, in an area of more than 20,000 square miles in northeastern Wisconsin, are important for NAWQA's assessment of groundwater quality within the glacial aquifer system that extends across 26 States. All NAWQA reports are available online https://water.usgs.gov/ nawqa/bib/.

We hope this publication will provide you with insights and information to meet your waterresource needs and will foster increased citizen awareness and involvement in the protection and restoration of our Nation's waters. The information in this report is intended primarily for those interested or involved in resource management and protection, conservation, regulation, and policymaking at the regional and national levels.

Dr. Donald W. Cline

Associate Director for Water

U.S. Geological Survey 



\section{Contents}

Foreword
Abstract
Introduction
Purpose and Scope
Description of the Fox-Wolf-Peshtigo Study Area
Previous Hydrogeologic Investigations and Modeling Studies
Conceptual Model of the Groundwater System
Hydrogeologic Framework
Sources and Sinks
Mecharge




\section{Figures}

1. Map showing location of the Fox-Wolf-Peshtigo study area in Wisconsin and the glacial aquifer system of the conterminous United States...

2. Map showing major rivers and lakes within the Fox-Wolf-Peshtigo study area and model domain

3. Diagram showing conceptual model of groundwater flow in glacial and bedrock aquifers in the Fox-Wolf-Peshtigo study area

4. Map showing internal boundary packages used to simulate groundwater/surface-water interactions in the Fox-Wolf-Peshtigo models

5. Maps showing $A$, land cover; $B$, hydrologic soils groups; $C$, estimated irrigated areas; and $D$, initial estimate of annual deep infiltration computed by the Soil-Water-Balance program, for the Fox-Wolf-Peshtigo groundwater-flow models....13

6. Maps showing $A$, the original bedrock elevation surface by Soller (written commun., 2016) and $B$, the final bedrock surface after adjusting for differences with measured depths to bedrock from well logs from the standardized lithologic database by Bayless and others (2017)

7. Map showing glacial categories used to represent hydraulic conductivity zones or to relate coarse fractions to heterogeneous hydraulic conductivity values in the Fox-Wolf-Peshtigo groundwater-flow models

8. Map showing composite coarse fraction for model cells that contain lithologic logs from the standardized lithologic database by Bayless and others (2017).

9. Maps showing cell-by-cell coarse fraction for glacial deposits in the 5-layer heterogeneous model in $A$, layer $1 ; B$, layer 2; and $C$, layer 3 .

10. Example graph showing a fitted exponential interpolation through points associating minimum, mean, and maximum coarse fraction with initial estimates of minimum, expected, and maximum hydraulic conductivity for the sandy till glacial category in layer 1 of the 5 -layer heterogeneous model

11. Maps showing targets used to calibrate the Fox-Wolf-Peshtigo models for $A$, stream base flow and $B$, water level

12. Maps showing water-level residuals for the $A, 1$-layer model; $B$, 5 -layer zoned model; and $C, 5$-layer heterogeneous model

13. Maps showing base-flow residuals for the $A, 1$-layer model; $B$, 5 -layer zoned model; and $C$, 5 -layer heterogeneous model

14. Maps showing calibrated horizontal hydraulic conductivity for glacial deposits of the 5-layer heterogeneous model in $A$, layer $1 ; B$, layer 2; and $C$, layer 3 .

15. Maps showing calibrated horizontal hydraulic conductivity of the 5-layer heterogeneous model, as modified from the "intermediate" model of Feinstein and others (2016), in $A$, unconfined bedrock in layer 4 and $B$, confined bedrock in layer 5 .....

16. Maps showing the 5 -layer heterogeneous model of $A$, calibrated horizontal to vertical anisotropy for glacial deposits; $B$, vertical hydraulic conductivity in layer 1 ; $C$, vertical hydraulic conductivity in layer 2 ; and $D$, vertical hydraulic conductivity in layer 3 .

17. Maps showing calibrated vertical hydraulic conductivity of the 5-layer heterogeneous model, as modified from the "intermediate" model of Feinstein and others (2016), in $A$, unconfined bedrock in layer 4 and $B$, confined bedrock in layer 5

18. Map showing the calibrated recharge pattern for the 5 -layer heterogeneous model 
19. Maps showing change in water-level target residuals between $A$, the 5 -layer zoned model and the 1-layer model and $B$, the 5 -layer heterogeneous model and the 5-layer zoned model

\section{Tables}

1. Horizontal hydraulic conductivities from previous modeling studies in northeastern Wisconsin

2. Association of Quaternary Atlas "Geocode" attribute codes with glacial categories

3. Association of Groundwater Site Inventory descriptors with coarseness codes used to compute coarse fractions for model cell nodes

4. Summary statistics for the coarse fraction computed for each glacial category by glacial model layer

5. Computed minimum, mean, and maximum coarse fraction for each glacial category in each glacial model layer and associated initial estimates of minimum, expected, and maximum horizontal hydraulic conductivity

6. National Water-Quality Assessment networks for which wells were used as water-level targets, regardless of the number of water-level measurements

7. Estimated vertical error in water-level measurements based on the Groundwater Site Inventory method of measurement codes that were used to compute water-level target weights for wells in the National Water Information System

8. Estimated vertical error in water-level measurements based on the Groundwater Site Inventory water-level accuracy codes that were used to compute water-level target weights for wells in the National Water Information System

9. Estimated vertical error in water-level measurements based on the Groundwater Site Inventory water-level source codes that were used to compute water-level target weights for wells in the National Water Information System

10. Estimated vertical error in target water level based on percentiles of the number of water-level measurements for individual wells, as used to compute water-level target weights for wells in the National Water Information System

11. Estimated vertical error in water-level measurements based on horizontal well location accuracy as estimated from collection method codes in appendix B from Wisconsin Department of Natural Resources (2001)

14. Multiplier parameters used to calibrate streambed conductance, recharge, and hydraulic conductivity of the bedrock aquifers in the Fox-Wolf-Peshtigo MODFLOW models

12. Parameters used to calibrate hydraulic conductivity of the glacial sediments in the 1-layer and 5-layer zoned Fox-Wolf-Peshtigo MODFLOW models

13. Parameters used to calibrate hydraulic conductivity of the glacial sediments in the 5-layer heterogeneous Fox-Wolf-Peshtigo MODFLOW model

15. Calibrated hydraulic conductivity of the glacial sediments for the 1-layer model..........37

16. Calibrated hydraulic conductivity of the glacial sediments for the 5-layer zoned model

17. Calibrated hydraulic conductivity of the glacial sediments for the 5-layer heterogeneous model.

18. Summary statistics for each model using water-level targets in the glacial aquifer system. 
19. Summary statistics for each model using all base-flow targets ....................................44

20. Change in absolute error for water-level targets in the glacial aquifer system ...............45

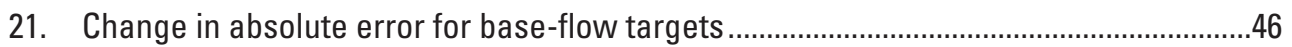

\section{Conversion Factors}

U.S. customary units to International System of Units

\begin{tabular}{|c|c|c|}
\hline Multiply & By & To obtain \\
\hline \multicolumn{3}{|c|}{ Length } \\
\hline inch (in.) & 2.54 & centimeter $(\mathrm{cm})$ \\
\hline foot $(\mathrm{ft})$ & 0.3048 & meter $(\mathrm{m})$ \\
\hline mile (mi) & 1.609 & kilometer $(\mathrm{km})$ \\
\hline \multicolumn{3}{|c|}{ Area } \\
\hline acre & 4,047 & square meter $\left(\mathrm{m}^{2}\right)$ \\
\hline square mile $\left(\mathrm{mi}^{2}\right)$ & 259.0 & hectare (ha) \\
\hline square mile $\left(\mathrm{mi}^{2}\right)$ & 2.590 & square kilometer $\left(\mathrm{km}^{2}\right)$ \\
\hline \multicolumn{3}{|c|}{ Volume } \\
\hline cubic foot $\left(\mathrm{ft}^{3}\right)$ & 0.02832 & cubic meter $\left(\mathrm{m}^{3}\right)$ \\
\hline \multicolumn{3}{|c|}{ Flow rate } \\
\hline foot per day (ft/d) & 0.3048 & meter per day $(\mathrm{m} / \mathrm{d})$ \\
\hline cubic foot per second $\left(\mathrm{ft}^{3} / \mathrm{s}\right)$ & 0.02832 & cubic meter per second $\left(\mathrm{m}^{3} / \mathrm{s}\right)$ \\
\hline cubic foot per day $\left(\mathrm{ft}^{3} / \mathrm{d}\right)$ & 0.02832 & cubic meter per day $\left(\mathrm{m}^{3} / \mathrm{d}\right)$ \\
\hline gallon per day (gal/d) & 0.003785 & cubic meter per day $\left(\mathrm{m}^{3} / \mathrm{d}\right)$ \\
\hline inch per year (in/yr) & 25.4 & millimeter per year (mm/yr) \\
\hline \multicolumn{3}{|c|}{ Hydraulic conductivity } \\
\hline foot per day $(\mathrm{ft} / \mathrm{d})$ & 0.3048 & meter per day $(\mathrm{m} / \mathrm{d})$ \\
\hline \multicolumn{3}{|c|}{ Transmissivity* } \\
\hline foot squared per day $\left(\mathrm{ft}^{2} / \mathrm{d}\right)$ & 0.09290 & meter squared per day $\left(\mathrm{m}^{2} / \mathrm{d}\right)$ \\
\hline
\end{tabular}

Temperature in degrees Fahrenheit $\left({ }^{\circ} \mathrm{F}\right)$ may be converted to degrees Celsius $\left({ }^{\circ} \mathrm{C}\right)$ as follows:

$$
{ }^{\circ} \mathrm{C}=\left({ }^{\circ} \mathrm{F}-32\right) / 1.8 \text {. }
$$

\section{Datum}

Vertical coordinate information is referenced to the North American Vertical Datum of 1988 (NAVD 88).

Horizontal coordinate information is referenced to the North American Datum of 1983 (NAD 83). Altitude, as used in this report, refers to distance above the vertical datum.

\section{Supplemental Information}

Transmissivity: The standard unit for transmissivity is cubic foot per day per square foot times foot of aquifer thickness ([ft $\left.\left.\mathrm{ft}^{3} \mathrm{~d}\right] / \mathrm{ft}^{2}\right) \mathrm{ft}$. In this report, the mathematically reduced form, foot squared per day $\left(\mathrm{ft}^{2} / \mathrm{d}\right)$, is used for convenience. 


\title{
Simulation of Groundwater Flow in the Glacial Aquifer System of Northeastern Wisconsin with Variable Model Complexity
}

\author{
By Paul F. Juckem, Brian R. Clark, and Daniel T. Feinstein
}

\section{Abstract}

The U.S. Geological Survey, National Water-Quality Assessment seeks to map estimated intrinsic susceptibility of the glacial aquifer system of the conterminous United States. Improved understanding of the hydrogeologic characteristics that explain spatial patterns of intrinsic susceptibility, commonly inferred from estimates of groundwater age distributions, is sought so that methods used for the estimation process are properly equipped. An important step beyond identifying relevant hydrogeologic datasets, such as glacial geology maps, is to evaluate how incorporation of these resources into process-based models using differing levels of detail could affect resulting simulations of groundwater age distributions and, thus, estimates of intrinsic susceptibility.

This report describes the construction and calibration of three groundwater-flow models of northeastern Wisconsin that were developed with differing levels of complexity to provide a framework for subsequent evaluations of the effects of process-based model complexity on estimations of groundwater age distributions for withdrawal wells and streams. Preliminary assessments, which focused on the effects of model complexity on simulated water levels and base flows in the glacial aquifer system, illustrate that simulation of vertical gradients using multiple model layers improves simulated heads more in low-permeability units than in high-permeability units. Moreover, simulation of heterogeneous hydraulic conductivity fields in coarse-grained and some fine-grained glacial materials produced a larger improvement in simulated water levels in the glacial aquifer system compared with simulation of uniform hydraulic conductivity within zones. The relation between base flows and model complexity was less clear; however, the relation generally seemed to follow a similar pattern as water levels. Although increased model complexity resulted in improved calibrations, future application of the models using simulated particle tracking is anticipated to evaluate if these model design considerations are similarly important for understanding the primary modeling objectiveto simulate reasonable groundwater age distributions.

\section{Introduction}

The National Water-Quality Assessment (NAWQA) is charged with mapping intrinsic susceptibility of groundwater across the glacial aquifer of the conterminous United States. Eberts and others (2013) defined intrinsic susceptibility as "a measure of the ease with which a contaminant in water can enter and move through an aquifer. It is a characteristic of the aquifer and overlying material, and it is independent of the contaminant characteristics or source." An important indicator of intrinsic susceptibility is groundwater age, with younger ages indicating either recent recharge or rapid movement and, therefore, potential susceptibility to contamination from activities at the land surface; older water is commonly more susceptible to mobilization of natural contaminants because of geochemical processes. As a result, understanding of the rate and spatial pattern of groundwater recharge, combined with groundwater velocities within the glacial aquifer system is an important component for estimating intrinsic susceptibility across the glacial aquifer.

Because of the complexity and large scale of the glacial aquifer, which extends from the east coast to the west coast and covers parts of many states in the northern conterminous United States (fig. 1), a metamodeling approach is envisioned for mapping the aquifer's intrinsic susceptibility. Metamodels are statistical models that are trained on output from processbased computer models and, thus, are liberated from many of the constraints of complex processed-based groundwater-flow models, such as long runtimes and spatial extent (Fienen and others, 2015). Inputs to the metamodels will likely include maps of important hydrogeologic properties, such as aquifer thickness, groundwater recharge, and glacial lithology. Training, or calibration, of the metamodels is expected to include a comparison of the metamodel outputs with simulated age distributions from process-based groundwater-flow and advective transport models, such as MODFLOW and MODPATH. However, additional work is needed to understand how differing means of interpretation and integration of the surficially mapped datasets into a three-dimensional groundwater modeling framework may affect the simulated age distributions that will be used to train the metamodels. 

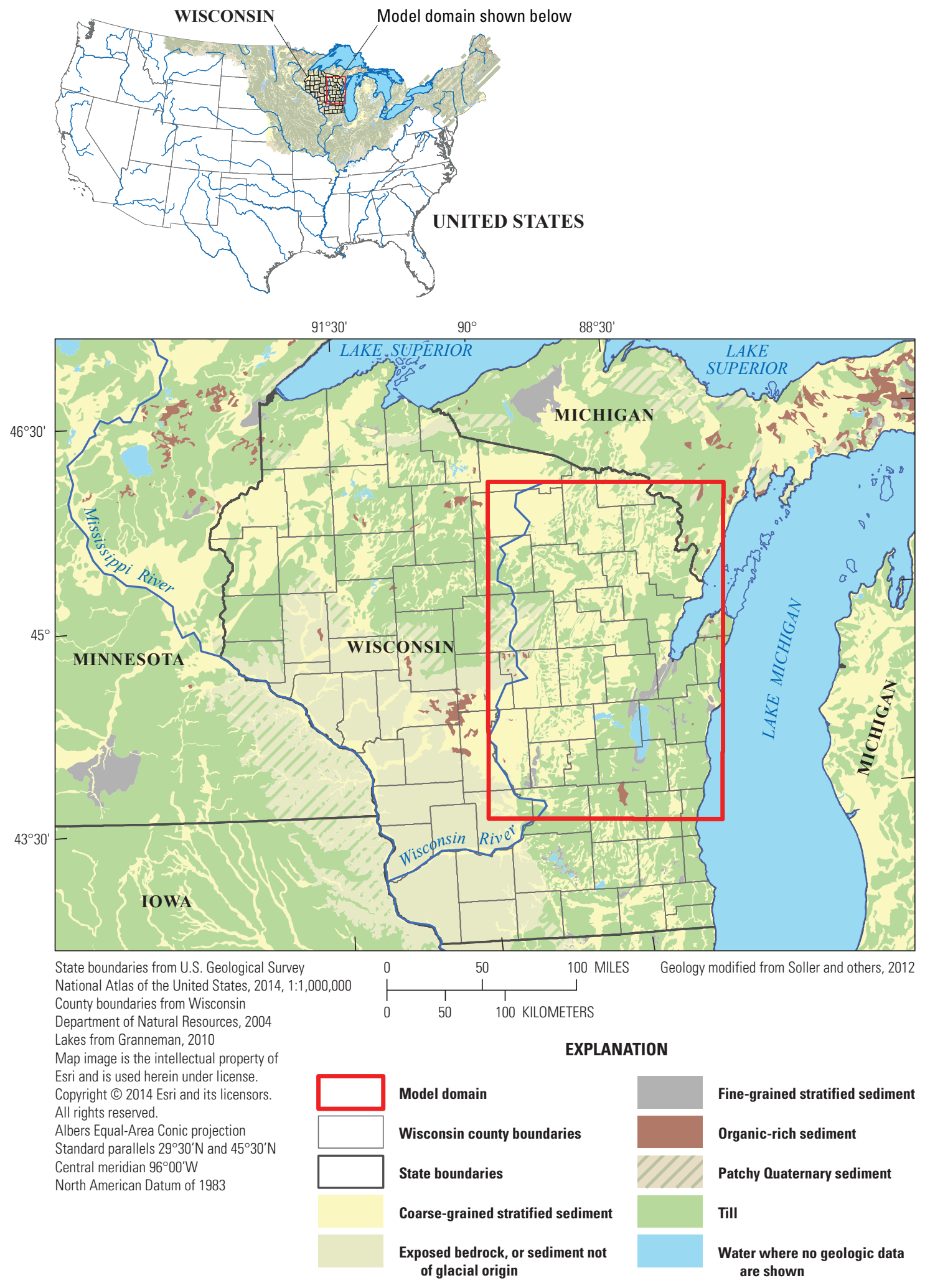

Figure 1. Location of the Fox-Wolf-Peshtigo study area in Wisconsin and the glacial aquifer system of the conterminous United States. 
This report describes the construction and calibration of three groundwater-flow models that were developed with differing levels of complexity to simulate groundwater flow in an area focused on the Fox, Wolf, Peshtigo, and surrounding watersheds in northeastern Wisconsin (fig. 1). Results focus on comparing the difference in simulated water levels within the glacial aquifer system among the three levels of model complexity. These models also form the framework for future evaluations focused on the effects of model complexity on simulated groundwater age distributions using particle tracking.

\section{Purpose and Scope}

The purpose of this report is to describe the conceptualization, construction, and calibration of three steady-state groundwater-flow models of varying complexity for the FoxWolf-Peshtigo (FWP) study area and evaluate how changes in model complexity affect simulated water levels and base flows. The models also are planned to be used for future evaluations of the effects of model complexity on simulated groundwater travel times from the water table to wells and streams. The three levels of complexity that were incorporated into the MODFLOW models are as follows: (1) a 1-layer model with zoned hydraulic conductivity representing the glacial unconsolidated aquifer, (2) a 5-layer model with three layers of zoned hydraulic conductivity representing the glacial aquifer plus two bedrock layers, and (3) a 5-layer model with three layers of heterogeneous hydraulic conductivity representing the glacial aquifer plus two bedrock layers. Future comparisons of simulated groundwater age distributions using these models are anticipated to inform tradeoffs between model complexities and simulated age tracer concentrations at sampled wells. The scope of this report is limited to describing the construction and calibration of the models to provide a framework for future model applications and to start the complexity analysis by comparing the effect of differing complexity on simulated water levels and surface-water fluxes in the glacial aquifer system.

This report documents the (1) conceptualization of the groundwater-flow system in the FWP study area; (2) tools and methods used to construct the groundwater-flow models with varying levels of complexity; (3) calibration of the groundwater models, including their parameters and targets; and (4) comparison of calibration statistics and water levels among the three groundwater-flow models. The purpose of the information in this report is as follows:

- to contribute to the understanding of groundwater flow in a part of the glacial aquifer that exhibits large ranges in lithology (from fine-grained glacial lake deposits to coarse-grained glacial outwash) and depth (from a few feet thick to approximately 600 feet thick; Soller and others, 2012);
- to describe a transferable method for combining quaternary geologic maps with a standardized lithologic database to generate grids of heterogeneous hydraulic conductivity (the method facilitates the incorporation of hydrogeologic knowledge in how mapped deposits are represented and flexibility in how hydraulic conductivity is estimated during the calibration process using parameter estimation tools);

- to quantify improvement in simulated water levels and surface-water fluxes in the glacial aquifer system in response to increased model complexity and identify geologic conditions in which additional complexity may be most advantageous; and

- to provide a platform for subsequent evaluations of simplification or complexity on the simulation of groundwater travel times as related to aquifer intrinsic susceptibility.

\section{Description of the Fox-Wolf-Peshtigo Study Area}

The FWP study area was chosen for this analysis because of the complex glacial deposits (Soller and others, 2012) and an abundance of age tracer data collected from wells and below some streams in the study area (Saad, 1997; Saad and Thorstenson, 1998; Saad, 2008; Tesoriero and others, 2013). Although not used for the work described in this report, comparison of simulated and measured age tracer concentrations can provide insight into processes that affect groundwater travel times and are expected to be of interest for future analyses with the models described herein.

The Fox River and its largest tributary, the Wolf River, are part of the Lake Michigan watershed (fig. 2). The Fox and Wolf Rivers flow from headwater areas along the Great Lakes-Mississippi River subcontinental divide, through Lake Winnebago, and ultimately discharge to Green Bay. The Oconto and Peshtigo Rivers, along with Duck Creek and Pensaukee River (fig. 2), drain the area north of Lake Winnebago and also discharge into Green Bay. The Fox River watershed from the mouth at Green Bay to the headwater tributaries covers 6.4 thousand square miles, with the remaining watersheds in the study area covering 2.7 thousand square miles. For this work, the model domain also includes tributaries to the Wisconsin River, including the Plover, Eau Claire, and Pine Rivers, as well as several creeks west of Waupaca (fig. 2). Lakes and wetlands are common throughout the study area, especially in the northern forested part of the study area. The landscape is closely tied to glacial landforms, with glacial moraines forming many watershed divides. The highest point, at approximately 1,910 feet above the North American Vertical Datum of 1988 (NAVD 88), is Sugarbush Hill in the headwaters of the Wolf River; the lowest elevation is Lake Michigan at approximately 580 feet above NAVD 88 . 


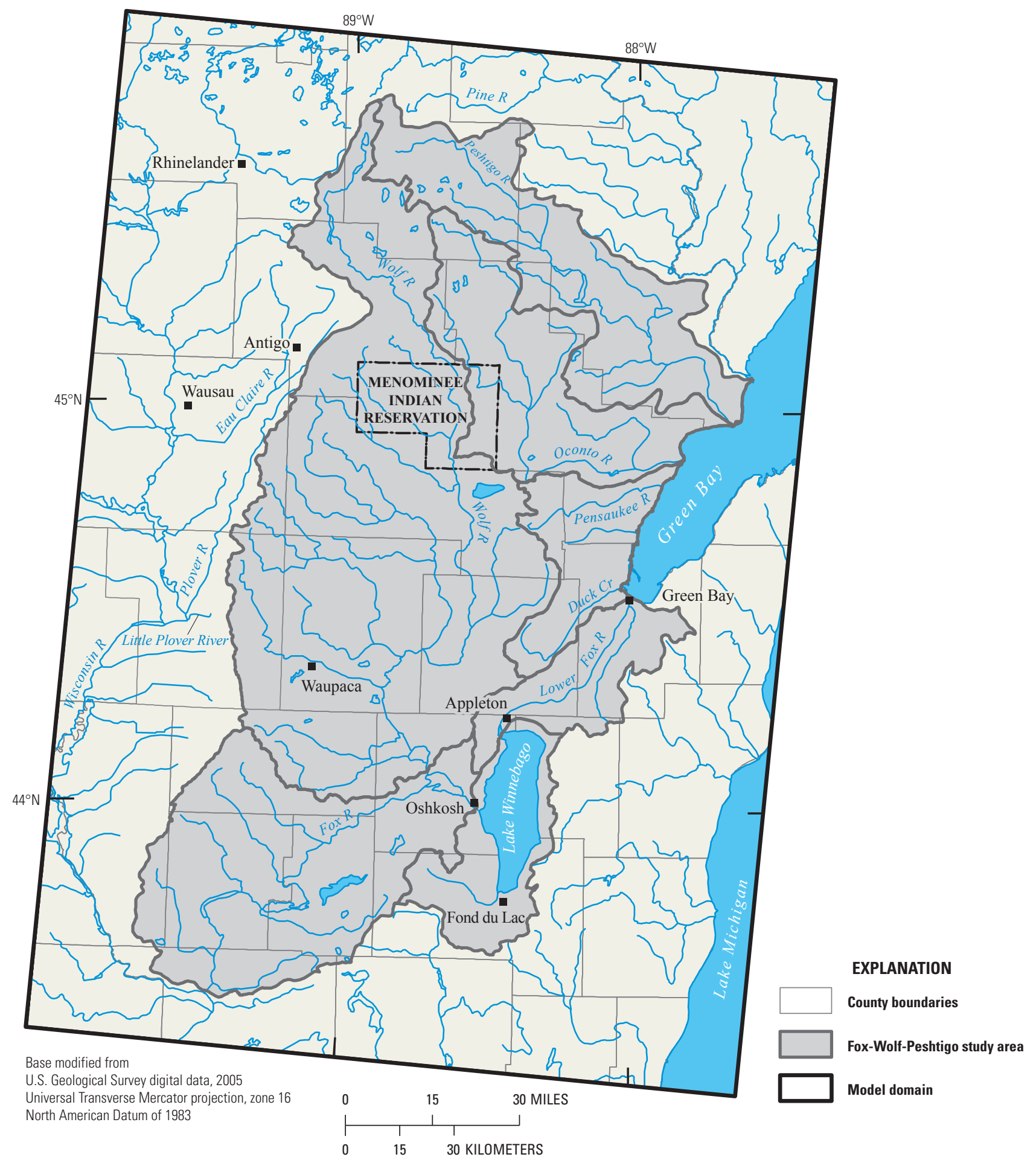

Figure 2. Major rivers and lakes within the Fox-Wolf-Peshtigo study area and model domain. 
The FWP study area experiences a northern temperate climate. As reported for the City of Green Bay, the mean annual precipitation is about 30 inches per year (in/yr). Mean daily temperatures typically range from about 9 degrees Fahrenheit in January to about 80 degrees Fahrenheit in July (National Oceanic and Atmospheric Administration, summary of monthly normal 1981-2010, accessed May 6, 2016, at http://www.aos.wisc.edu/ sco/clim-history/sta-data/grb/ GRB-Monthly/GHCND_USW00014898_2010-1-1.pdf). Mean snowfall is approximately 51 in/yr (National Oceanic and Atmospheric Administration, Annual Climate Report 1981-2010, accessed November 7, 2016, by selecting the CLA product at http://w2.weather.gov/climate/?wfo=grb), and soils usually freeze to several feet of depth during each winter.

Groundwater withdrawals in the study area are commonly concentrated in agricultural and urban settings. Feinstein and others (2010) include a description of the history of groundwater withdrawals and source aquifers in eastern Wisconsin, which is summarized here. Agricultural irrigation in the FWP study area has increased during several decades and most withdrawal is from sandy areas in the glacial aquifer, predominantly within the Wisconsin River watershed. Groundwater withdrawal in urban areas, such as along the Lower Fox River between Appleton and Green Bay, is primarily from sandstone and dolostone bedrock. The public water supply for the city of Green Bay (fig. 2) was switched from bedrock wells to Lake Michigan water in 1957, and between 2006 and 2007, an additional eight smaller community water systems (a reduction in withdrawals of 12.25 million gallons per day) stopped using groundwater and switched to surface-water sources. The initial conversion by Green Bay and subsequent conversion resulted in an initial and subsequent rebound of heads in the deep confined bedrock aquifers, but a cone of depression remains in the Fox River valley because of a lagged response and continued pumping by smaller communities along the Fox River valley.

\section{Previous Hydrogeologic Investigations and Modeling Studies}

Several notable hydrogeologic investigations overlap with all or a part of the FWP study area. The Lake Michigan Basin (LMB) groundwater-flow model (Feinstein and others, 2010) compiled extensive water use and bedrock geology information for the area, although the area west of approximately Lake Winnebago was treated as "far field" and, therefore, was only coarsely represented in the LMB model. Similar to the methods described later in this report, hydraulic conductivities for glacial deposits in the LMB model were estimated using simplifications of mapped glacial categories and local lithologies from standardized well construction reports. Calibrated horizontal hydraulic conductivities for glacial deposits in the LMB model ranged from 0.8 to 596 feet per day $(\mathrm{ft} / \mathrm{d})$. The LMB model used 20 layers to vertically represent aquifers and confining units, 17 of which represented bedrock units. A subsequent semistructured version of the LMB model, in which the top glacial aquifer layer was refined to a 500 -foot by 500 -foot resolution, was developed to focus more on shallow groundwater-surface-water exchange (Feinstein and others, 2016). For this semistructured model, the 17 bedrock layers used by Feinstein and others (2010) for the LMB model were compressed into two bedrock layers approximately representing confined and unconfined bedrock units.

A 2016 study of the Little Plover River in the Wisconsin River watershed focused on understanding relations between agricultural water use and stream base flows (Bradbury and others, in press). This study used a soil-water balance model to compute groundwater recharge estimates. The land-cover map used by the soil-water balance model was compared to actual planted crops, and extensive field checking identified an approximate 80 percent agreement. Agricultural irrigation was also used in the soil-water balance model, in which an irrigation rate of 0.5 inch per day was applied to irrigated fields based on input from local farmers. This represented the approximate rate of water applied to a field while a centerpivot irrigation system rotated one time per day over a field. Based on input from farmers, Bradbury and others (in press) estimated that most irrigation systems began when soil moisture reached approximately 60 percent of the soils' field capacity, regardless of crop type.

Several regional modeling studies have evaluated groundwater flow patterns, have evaluated effects of groundwater pumping on water levels and streamflows, and have mapped areas that contribute groundwater recharge to wells. Juckem and Dunning (2015) used an analytic element model to simulate probability-based areas contributing recharge to wells on the Menominee Indian Reservation, where little water-level data exists. Zones of hydraulic conductivity representing the glacial deposits were calibrated, with values ranging from 4 to $65 \mathrm{ft} / \mathrm{d}$. Kraft and Mechenich (2010) simulated water-level declines and stream base-flow reductions caused by estimated reductions in equivalent groundwater recharge attributed to enhanced evapotranspiration because of irrigation with water pumped from the groundwater system in central Wisconsin. Recharge for the model in Kraft and Mechenich (2010) ranged from 4 to $16 \mathrm{in} / \mathrm{yr}$, with calibrated hydraulic conductivity of the glacial deposits ranging from 3 to $328 \mathrm{ft} / \mathrm{d}$. Krohelski (1986) and Conlon (1998) described bedrock aquifers along the Lower Fox River valley where these aquifers have historically supplied water to numerous communities. 


\section{Conceptual Model of the Groundwater System}

Development of a groundwater-flow model builds on a conceptualization of the underlying hydrogeologic system and its interaction with surface-water bodies and wells. A simplified hydrostratigraphic cross section, modified from Kammerer and others (1998), was developed as the foundation of the conceptual model (fig. 3) for the FWP study area. Groundwater-surface-water exchange is expected to be focused within the shallow glacial aquifer system (Feinstein and others, 2016), with groundwater generally discharging to surfacewater bodies and only local recirculation of surface water back into the aquifer. Wells withdraw water from coarse-grained glacial deposits (primarily in the west where Precambrian crystalline rocks provide little yield) and also from unconfined and confined bedrock aquifers that increase in thickness to the east.

\section{Hydrogeologic Framework}

Groundwater flows through two primary aquifer types in the FWP study area - the surficial glacial aquifer system and the underlying bedrock aquifer systems (fig. 3). In the north and western parts of the study area, the glacial aquifer directly overlies impermeable crystalline bedrock and represents the primary aquifer. In the southern and eastern parts of the study area, permeable sandstone and dolostone aquifers provide substantial storage and transmissivity, whereas the glacial deposits generally contain greater amounts of fine-grained material. The bedrock surface, which separates the glacial and bedrock aquifers, is generally irregular; therefore, the overlaying glacial deposits exhibit a high degree of variability in thickness.

The glacial materials in the FWP study area exhibit differing lithology because of the depositional environment in which the materials were deposited (Lineback and others, 1983; Farrand and others, 1984). Although written descriptions of the mapped surficial deposits are generally limited to the upper few meters (Lineback and others, 1983; Farrand and others, 1984), lithologic analysis of well construction reports (see the "Hydraulic Conductivity" section) indicate little variation with depth compared to horizontal transitions in lithology. As a result, maps of the surficial glacial units within the FWP study area are expected to remain useful for understanding geologic properties of the glacial aquifer system at all depths. This assumption may not be appropriate in other areas of the glacial aquifer system in the United States where deep glacial deposits are associated with multiple and more complex glacial advances and retreats.

Sandstone and dolostone rocks overlay crystalline bedrock that forms a ridge along the Wisconsin arch, a southern extension of the Precambrian Canadian Shield that forms a peninsular shape between the Michigan Basin to the east, the Illinois Basin to the south, and the Hollendale Embayment
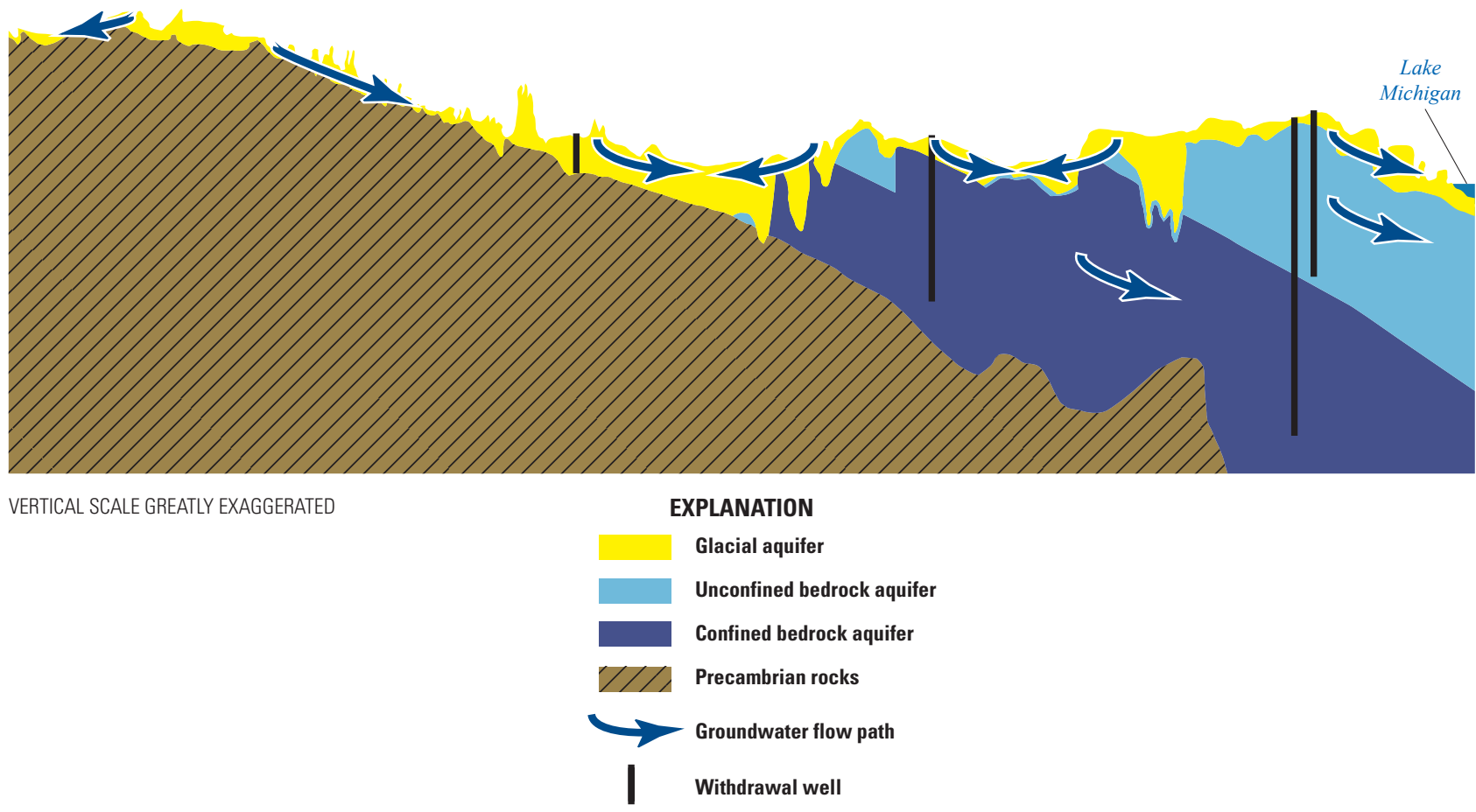

Figure 3. Conceptual model of groundwater flow in glacial and bedrock aquifers in the Fox-Wolf-Peshtigo study area. 
(Mossler, 1992) to the west. In the FWP study area, these sedimentary bedrock units dip toward the east, cumulatively increasing in thickness toward the Michigan Basin. Given the focus this project has on the glacial aquifer system, the simplified two-bedrock aquifer representation used by Feinstein and others (2016) was adopted for this work. That is, as shown in figure 3, the bedrock formations have been simplified into an upper unconfined bedrock aquifer and an underlying confined bedrock aquifer. With this conceptualization, no single regionally continuous stratigraphic confining unit separates the two bedrock systems. Instead, the upper-most locally important confining unit is used to separate the upper and lower systems, with the confining unit considered to be part of the underlying confined system. Although the bedrock aquifers are an important source of water supply and have been the primary focus of prior investigations, bedrock aquifers are included in this study primarily to account for their potential effect on the bulk aquifer transmissivity and thickness, and therefore, potential effects on groundwater ages within the glacial aquifer. In addition, the large cone of depression that was caused by historical and contemporary well withdrawal in the bedrock aquifers along the Lower Fox River valley was depicted by Feinstein and others (2010) to divert some groundwater from the overlying glacial aquifer into the bedrock system, which is expected to locally affect simulated groundwater ages.

\section{Sources and Sinks}

Stresses on the groundwater flow system include fluxes into the aquifers (sources) and discharges from the aquifers (sinks). Sources of water to the glacial aquifer include recharge at the water table, surface-water leakage into the aquifer, and leakage of groundwater upward from the bedrock aquifers. Sinks of groundwater from the glacial aquifer includes discharge to surface-water bodies, discharge to withdrawal wells, and downward leakage into bedrock aquifers. Most streams and lakes are expected to be well connected with the underlying glacial aquifer. The hydrologic connection between the glacial aquifer and overlying wetlands is less clear. Some wetlands, such as boreal rich fens (Epstein and others, 2002), are well connected with the groundwater flow system; others, such as hardwood swamps (Epstein and others, 2002), may be fed primarily by surface runoff and are poorly connected with the underlying aquifers. Representation of these sources and sinks in the FWP models is described in the "Model Construction" section.

Most of the sources and sinks fluctuate seasonally, but are generally in equilibrium on an annual or longer-term basis and approximate steady-state conditions. However, groundwater pumping in the study area has been dynamic over several decades, with withdrawals from the glacial aquifer increasing over several decades and withdrawals from the confined sandstone and carbonate aquifers increasing and then decreasing over the past half century (see the Description of the FoxWolf-Peshtigo Study Areas section). Nonetheless, water levels in the unconfined glacial aquifer are expected to respond rapidly to changes in pumping, minimizing transient responses to pumping. Water levels in the confined bedrock aquifers do not respond as quickly. However, given that the focus of this work is on the unconfined glacial aquifer system, and that the models incorporate long-term average pumping (see the Well Withdrawals section) and calibration data that spans several decades (see the Calibration section), water levels and groundwater flow through the glacial aquifer system were assumed to be adequately represented with steady-state conditions.

\section{Hydrogeologic Characteristics of the Groundwater-Flow System}

Initial estimates of hydraulic conductivity, recharge, and streambed leakance for the FWP models were based on previous investigations in Wisconsin and other Great Lakes states (table 1). Horizontal hydraulic conductivities of glacial deposits are reported to range from 0.02 to $596 \mathrm{ft} / \mathrm{d}$. Horizontal hydraulic conductivities in the bedrock aquifers are generally lower than those in the glacial aquifer and are reported to range from 0.06 to $145 \mathrm{ft} / \mathrm{d}$. Vertical hydraulic conductivities in the glacial aquifer and the sandstone aquifer are expected to range as much as several orders of magnitude lower than the corresponding estimates of horizontal hydraulic conductivity. Although these ranges are useful for characterizing the system, the MODFLOW models require specific values of hydraulic conductivity for the aquifer systems. Thus, hydraulic conductivities were treated as calibration parameters for the models and are discussed in the "Model Construction" and "Model Calibration" sections.

\section{Recharge}

Recharge occurs at the water table across the study area, except locally where groundwater discharges to surface-water features. Gebert and others (2011) estimated base flow and recharge for hundreds of small watersheds in Wisconsin using base-flow separation techniques and regression of low-flow characteristics among partial-record stations. Based on Gebert and others (2010), recharge rates within the FWP model domain ranged from less than $1 \mathrm{in} / \mathrm{yr}$ to greater than $14 \mathrm{in} / \mathrm{yr}$, with a pattern of high recharge rates in the western part of the model domain decreasing to low recharge rates along Green Bay and Lake Michigan. This recharge pattern follows that of the glacial deposit lithologies, with coarse-grained deposits in the west transitioning to finer-grained deposits in the east (Lineback and others, 1983; Farrand and others, 1984). 
Table 1. Horizontal hydraulic conductivities from previous modeling studies in northeastern Wisconsin.

$[--$, no data; $<$, less than $]$

\begin{tabular}{lcccccc}
\hline & \multicolumn{5}{c}{ Horizontal hydraulic conductivity (foot per day) } \\
\cline { 2 - 7 } Hydrogeologic unit & Krohelski (1986) & $\begin{array}{c}\text { Kraft and Mech- } \\
\text { enich (2010) }\end{array}$ & $\begin{array}{c}\text { Feinstein and } \\
\text { others (2010) }\end{array}$ & $\begin{array}{c}\text { Juckem and } \\
\text { Dunning (2015) }\end{array}$ & $\begin{array}{c}\text { Feinstein and } \\
\text { others (2016) }\end{array}$ & This report \\
\hline Glacial aquifer & -- & $3.3-330$ & $<1-596$ & $4-65$ & $0.02-441$ & $1-487$ \\
Bedrock aquifer & $2-8$ & $3.3-52$ & $<1-37$ & -- & $0.06-145$ & $0.05-115$ \\
\hline
\end{tabular}

\section{Streambed Leakance}

Estimates of streambed, lakebed, and wetland leakance were needed to simulate the interaction between surface water and groundwater. Leakance is equal to the vertical hydraulic conductivity of a streambed or lakebed divided by its thickness. The large variations in lithologies of the glacial aquifer were expected to exert strong control on leakage between the aquifer and water bodies. Thus, hydraulic conductivities of lakebeds and wetlands were assumed to match that of the underlying glacial aquifer on a cell-by-cell basis. Similarly, streambed hydraulic conductivity was expected to mimic the local glacial sediments; therefore, the cell-by-cell hydraulic conductivity of streambed sediment was set equal to that of the underlying glacial layer as well. For this study, all streambeds were assumed to be 1 foot thick. Calculation of leakance for surface-water features depended on how the water bodies were simulated in the model and is described in the "Model Construction" section.

\section{Model Construction}

Model construction involved generating input arrays (gridded data) that describe the spatial distribution of hydraulic conductivity of the aquifers, recharge to the aquifers, and top and bottom elevations for each model layer, as well as mapping curvilinear surface-water bodies to square cells and applying well withdrawal rates to cells and layers based on well construction information. The groundwater flow system was simulated with the groundwater-flow model MODFLOW-NWT (Niswonger and others, 2011), which relies on an upstream-weighted block-centered finite-difference method to solve the groundwater-flow equations (Harbaugh, 2005; Niswonger and others, 2011). The MODFLOW-NWT model was designed partially to address challenges caused by simulating thin unconfined aquifers (common in glaciated regions) that are susceptible to oscillatory dry-cell problems during the iterative solution. Dry cells occur when water levels fall below the layer bottom; MODFLOW-NWT minimizes this problem during the solution process by assigning a very small minimum thickness to each cell. For the final solution, MODFLOW-NWT assigns a user-specified value (-999 for the FWP models) for simulated heads in cells having a saturated thickness less than or equal to the specified minimum thickness, which was set at the default value of 0.00001 foot for the FWP models. Detailed discussions of finite-difference methods, MODFLOW input requirements, and theory are provided by McDonald and Harbaugh (1988), Anderson and Woessner (1992), Harbaugh and others (2000), Harbaugh (2005), and Anderson and others (2015).

Three MODFLOW models were developed to simulate the FWP study area with differing levels of model complexity and vertical discretization. However, much of the input to the models is shared in common among the three models, including the following: (1) initial recharge estimated by a Soil-Water-Balance (SWB) program (Westenbroek and others, 2010), (2) all boundary packages for simulating surface-water features, (3) an adjusted bedrock surface elevation representing the base of the glacial aquifer system, and (4) simplified glacial categories based on the Quaternary Atlas (Lineback and others, 1983; Farrand and others, 1984). The three models differ by the following: (1) the number of layers used to represent the glacial aquifer system, (2) whether bedrock aquifers were simulated or assumed to represent a lower no-flow boundary, and (3) the level of heterogeneity in the hydraulic conductivity fields used to represent the glacial aquifer deposits. Of the three models, two simulated the bedrock aquifers and included additional withdrawal wells and target water levels for wells that penetrated into the bedrock aquifers. These additional withdrawal wells and water-level targets were not included in the 1-layer model that neglected to simulate the bedrock aquifers. The following sections first describe many of the similarities among the three models, followed by descriptions of the distinguishing features.

\section{Model Grid}

The MODFLOW models were designed with square cells spanning 1,000 feet on each side, which resulted in 930 rows and 650 columns of cells per layer (604,500 cells per layer), covering 21,680 square miles. This level of grid resolution was chosen as a compromise between detailed representation of groundwater/surface-water interactions and reasonable constraints on computer resources required to construct and solve the model. Vertical discretization of the three hydrostratigraphic units identified in the conceptual model (fig. 3; the glacial aquifer, upper unconfined bedrock aquifer, and lower 
confined bedrock aquifer) varied among the three versions of the FWP model, as described in the "Model Layering" section.

\section{Boundary Conditions}

Perimeter hydrogeologic boundaries define the extent of the groundwater flow domain and characterize hydrologic conditions along the top, bottom, and perimeter of the model area. The water table represents the top of the groundwaterflow system and is the boundary where recharge enters the system; this boundary was directly simulated by the models. Precambrian crystalline rocks, which generally provide water to wells only when no other resource is available, are no-flow boundaries that underlie the base of the glacial and bedrock aquifer systems. In the limited case of considering only glacial deposits as an aquifer (the 1-layer model), the Cambrian to Silurian aged sandstones and dolostones were considered impermeable boundaries, although these units provide abundant water to withdrawal wells. The perimeter of the model was simulated with no-flow boundaries. To account for this simplification, the model domain was extended at least 8 miles beyond the primary study area to ensure that surrounding surface-water bodies were explicitly simulated within the models and provided the glacial aquifer system with a buffer from any potential boundary effects. Moreover, the Wisconsin River and Lake Michigan are effective hydrologic boundaries along the western and eastern model edges, in that little to no water is expected to flow beneath them through the glacial aquifer system because their water levels are the lowest levels in their respective regions. Feinstein and others (2010) determined that modern pumping from confined bedrock aquifers along the western shores of Lake Michigan has altered the deep flow system, causing some vertical leakage of Lake Michigan water out of the lake, and causing the size of the wells' capture areas within the deep aquifers to extend farther to the east beneath the lake. Nonetheless, given the focus of this work on the shallow glacial system, the cursory representation of the bedrock aquifer system, and the smaller flow rates through the bedrock aquifers compared with the glacial aquifers (Feinstein and others, 2010), the no-flow boundary along the eastern edge of the conceptual and numerical models below the Lake Michigan hydrologic boundary is expected to serve adequately for the modeling objectives described in this report. Internal boundaries such as streams, lakes and wetlands were simulated using MODFLOW boundary packages, as described in the next section.

\section{Surface-Water Network}

Internal hydrologic features in the MODFLOW model include streams, lakes, and wetlands (fig. 4) that were simulated with the general head boundary (GHB) package (Harbaugh and others, 2000), streamflow-routing (SFR2) package (Niswonger and Prudic, 2005), and Unsaturated-Zone Flow (UZF1) Package (Niswonger and others, 2006). Surface-water bodies were simulated using head-dependent boundary packages, for which groundwater flow to or from these surfacewater bodies depends on the difference between the surface water and groundwater levels, the vertical conductivity divided by the thickness of the underlying sediment (leakance), and the length and width of the water body in the model cells that encompass the surface-water body. Conductance for a head-dependent boundary package is the product of the length, width, and leakance (Anderson and others, 2015).

Lake Michigan and the Wisconsin River were simulated using the GHB package, in which the water level of these large features is specified. The assigned water level for GHB cells along the Wisconsin River was computed as the minimum elevation of pixels from a 10-meter resolution Digital Elevation Model (DEM; U.S. Geological Survey, 2014) contained within an individual 1,000-foot by 1,000-foot GHB model cell. The water level assigned to Lake Michigan GHB cells was specified as 580 feet above NAVD 88, which was the minimum elevation of all pixels from the 10-meter DEM that covered Lake Michigan. A uniform value of sediment conductance (100,000 feet squared per day) was applied to these GHB cells to ensure a high degree of connection with the groundwater flow system. This conductance value approximates a hydraulic conductivity of $0.1(\mathrm{ft} / \mathrm{d})$ for sediment that is 1 -foot thick, over an area that is 1,000 feet by 1,000 feet.

Streams within the model domain were simulated with the SFR2 package (Niswonger and Prudic, 2005), which routes water from upstream reaches to downstream reaches to accumulate flow and solve for water level in the stream. Every cell in the MODFLOW model that represents a stream in the SFR2 package is assigned a segment number and reach number. Reaches represent individual SFR2 cells, which are grouped together into SFR2 segments to facilitate downstream routing of water. The SFR2 package for the FWP models was developed from the National Hydrography Dataset Plus (NHDPlus; McKay and others, 2012), which guided the locations of stream segments and their downstream connections. Each polyline in the NHDPlus dataset contributed to a separate SFR2 segment containing one or more SFR2 reaches. The streambed in each cell was assumed to be 1-foot thick, with vertical hydraulic conductivity equal to the vertical conductivity of the underlying glacial material in layer 1 of the model for the dominant reach in each model cell. For cells with overlapping SFR2 reaches, an artificially low hydraulic conductivity $\left(1 \times 10^{-8} \mathrm{ft} / \mathrm{d}\right)$ was assigned to all reaches except for the one "dominant" reach that is associated with the most downstream segment; therefore, ensuring that only the most downstream-stream reach interacted with the aquifer. The stream length for each SFR2 reach was determined from the length of the associated NHDPlus polyline fragment crossing the model cell. Stream width was calculated as an arbolate sum (Bartošová and others, 2004), based on a relation between measured stream widths and the downstream distance from the headwater origin, as originally developed by Feinstein and others (2010). Elevations of the streambed in each SFR2 reach were derived from the lowest elevation of all values from a 


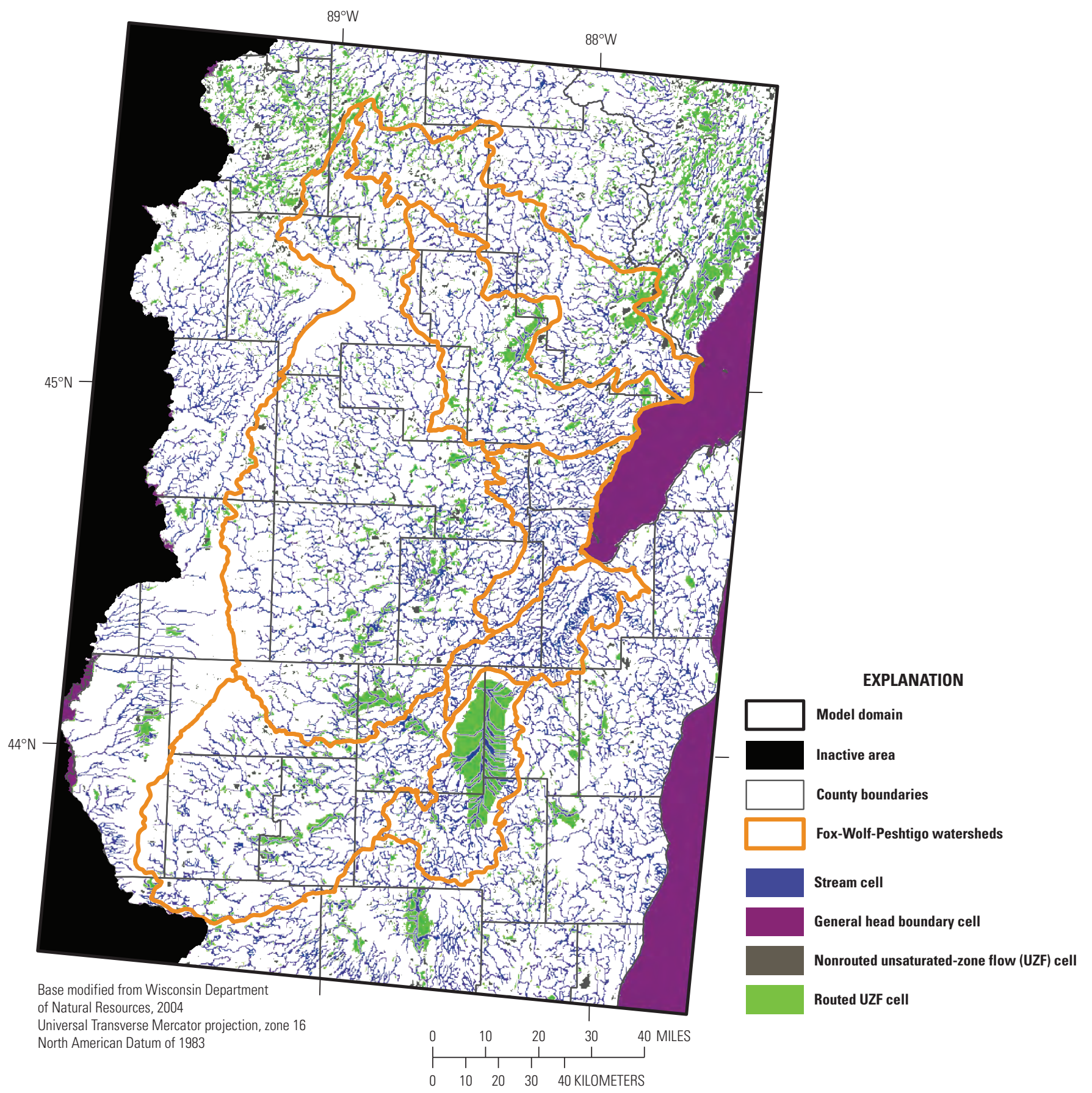

Figure 4. Internal boundary packages used to simulate groundwater/surface-water interactions in the Fox-Wolf-Peshtigo models. 
10-meter resolution DEM (U.S. Geological Survey, 2014) that overlapped with the MODFLOW cell containing the associated SFR2 reach. Streambed elevations were subsequently refined, such that all streambed elevations decreased from headwater reaches to the most downstream reach of the stream network. These refined elevations were then used to compute the stream slope for each reach, but constrained by a maximum slope of 0.2 foot per foot to improve model solution stability. The stream slope and channel roughness, specified as 0.037 for all reaches, were combined with the stream width and total simulated flow to compute stream stage via Manning's equation in each SFR2 reach (Prudic and others, 2004). Segments were subsequently subdivided into smaller segments at the point where they intersected with water bodies (lakes and wetlands) that were represented with the UZF1 package. Subdividing the SFR2 segments in this way facilitated routing of water between the UZF1 and SFR2 packages.

The UZF1 package was used as a flexible tool to simulate recharge to the aquifer or groundwater discharge to lakes and wetlands. That is, the model domain contains numerous lakes and wetlands, and their connection with the underlying aquifer can be difficult to understand without detailed site-specific investigation. For example, some wetlands are dependent on groundwater discharge; other wetlands obtain most of their water from precipitation or runoff and may leak some of this water into the aquifer. The UZF1 package provides a means to simulate groundwater recharge into the aquifer where the simulated water table is below the top of the model, yet simulate groundwater discharge to a surface-water body where the simulated water table is above the model top. For the FWP model, MODFLOW cell centers that intersected waterbody polygons from the NHDPlus dataset (McKay and others, 2012) were specified as UZF1 cells, except those cells that already contained an SFR2 reach. Deep infiltration computed by a soil water balance model (see the "Recharge" section) was assigned as an infiltration term for any overlapping UZF1 cells, and the corresponding cell in the recharge package was assigned zero recharge. Because much of the study area has low relief, and to ensure proper routing of potential rejected recharge or groundwater discharge to streams, the waterbody polygons were first clipped by the fine-scaled surface-water catchments included with the NHDPlus dataset (McKay and others, 2012). A lookup table was generated to facilitate routing of potential groundwater discharge from individual UZF1 cells to SFR2 segments by intersecting the waterbody polygons with polygons representing the SFR2 cells. That is, waterbodies that connected with streams were designed to route any groundwater discharge into the adjacent SFR2 stream network. Waterbodies that did not connect with streams did not route potential groundwater discharge, and if any discharge occurred, the discharge was assumed to evaporate or be transpired by plants and, thus, removed from the groundwater flow computations. Groundwater discharge is computed by the UZF1 package as a function of the height of the simulated water table above the model top and the cell conductance, computed as the area of the cell multiplied by the vertical hydraulic conductivity of the glacial deposits in the uppermost layer divided by one-half of the cell thickness.

An additional reason for simulating lakes and wetlands with the UZF1 package is that many small lakes and wetlands that gain groundwater discharge commonly function as weak sinks. Weak-sink cells are model cells for which groundwater flows into the cell on at least one, but not all, cell faces; strong-sink cells occur when groundwater flows into a cell along all cell faces. Weak-sink cells traditionally have been somewhat problematic for particle tracking simulations, in which mathematical particles of water are forward-tracked from the water table to a point of discharge (or in the opposite direction for backward tracking). Weak-sink cells can be problematic in that some water is removed from the groundwater flow system at the cell, but some water in the cell continues on, discharging at another location farther down gradient. Consequently, the time of travel for a simulated water particle, or the age of the particle, can differ greatly depending on whether the particle is stopped at a weak-sink cell or is allowed to pass through the cell, ultimately discharging at a strong-sink cell. Abrams and others (2013) identified a proper means for handling weak-sink cells associated with surfacewater bodies, such that particles that flow upward and intersect the top face of the cell (and discharge to the surface-water body) should be stopped, whereas upward-flowing particles that do not intersect the top face of the cell are allowed to pass through. This approach ensures proper simulation of groundwater ages in the presence of weak-sink cells that are associated with surface-water bodies, which was deemed an important consideration given the objectives of using the FWP models to simulate groundwater ages in the future.

\section{Recharge}

The long-term (approximately 1980-2012) mean rate of deep infiltration, or potential groundwater recharge, was computed using the SWB program described by Westenbroek and others (2010). The SWB program used a modified Thornthwaite-Mather (Thornthwaite and Mather, 1957) approach to partition daily precipitation into surface runoff and deep infiltration within a grid of 500 -foot by 500 -foot resolution cells covering the FWP model domain. The SWB program is effectively driven by gridded input of daily precipitation and air temperature from the Daymet dataset (Thornton and others, 2014). Gridded Soil Survey Geographic data (Soil Survey Staff, 2014) were used to estimate available water content of the soil and associated hydrologic soil groups. The hydrologic soil groups were connected to Natural Resources Conservation Service curve numbers (U.S. Department of Agriculture, 1986) through a lookup table, which controlled partitioning between surface runoff and infiltration as a function of daily precipitation and residual soil moisture. The mean elevation from a 10-meter DEM (U.S. Geological Survey, 2014) was computed for each 500 -foot cell, and any potential runoff from individual cells was routed to adjacent 
downslope cells where the runoff could potentially infiltrate. The 2011 National Land Cover Database (Homer and others, 2015) was used to map land cover across the model domain, which accounts for vegetation cover and associated rates of evapotranspiration and soil-moisture depletion in the SWB program. Finally, an estimated map of agricultural irrigation was added to the SWB program to account for potential excess recharge caused by overirrigation. A simple approach was used whereby a buffer of 240 acres was created around each high-capacity well that was identified as having an agricultural irrigation water use code in a water use database developed for this project (see the "Well Withdrawal" section). The 240-acre buffer was updated for each approximate 5-year period from 1980 to 2012 to account for the increase in irrigation wells with time. The Food and Agriculture Organization's Irrigation and Drainage Paper No. 56 (FAO-56) approach to computing daily transpiration potential for crops (Allen and others, 1998) was used to estimate the timing of irrigation for each irrigated area. Parameters describing the growth and utilization of water by plants were applied directly from the FAO-56 publication. For the FWP model, irrigation began when soils were estimated to be at approximately 60 percent of field capacity, and a uniform irrigation rate of 0.5 inch per day was applied until the soil moisture exceeded 60 percent of field capacity. The 0.5 -inch per day estimate for irrigation was based on previous research that involved discussions with farmers in the Little Plover watershed of central Wisconsin (Bradbury and others, in press). This simulated irrigation could result in additional recharge in cases where an initially dry soil received irrigation water prior to a substantial rain event. As a final step in the SWB program, all open water identified from the soils data or land use map were assigned zero recharge. Land cover, hydrologic soils groups, irrigated areas during 2006-12, and the long-term mean estimated deep infiltration or potential recharge computed by the SWB program are shown in figure 5 .

Long-term (approximately 1980-2012) deep infiltration estimated by the SWB program was input as groundwater recharge in the MODFLOW models through the recharge (RCH) package (Harbaugh, 2005) in upland areas and the UZF1 package (Niswonger and others, 2006) in low-lying areas identified as waterbodies by the NHDPlus (McKay and others, 2012). The SWB program does not consider the distance between the bottom of the root zone and the top of the water table; that is, the SWB program has no mechanism to estimate if the aquifer is able to accept the estimated deep infiltration water. For this reason, the MODFLOW UZF1 package was used to distribute and possibly reject the deep infiltration water estimated by SWB in low-lying areas identified as a waterbody in the NHDPlus dataset. Creation of the UZF1 package was described in the "Surface-Water Network" section.

\section{Well Withdrawals}

Buchwald and others (2010) tabulated groundwater withdrawals for high-capacity wells from 1864 to 2005 for use in the LMB model (Feinstein and others, 2010). That database was updated for the FWP models to include additional wells in the "far field" part of the LMB model, which overlaps with the western part of the FWP models. Additional wells that went into production between 2005 and 2012 also were added to the water use database. The addition of these wells resulted in 5,421 potential withdrawal wells for which the mean pumping rates from 1971 to 2012 were computed for each well in the steady-state FWP models. Pumping from high-capacity wells was assigned to model layers using the multi-node well (MNW2) package (Konikow and others, 2009), whereby pumping is distributed among model layers based on the relative transmissivities (horizontal hydraulic conductivity times layer thickness) of the penetrated layers. Most wells $(5,175)$ in the FWP water use database contained depth of casing and depth of well information that were used to compare to model layer elevations and to assign individual wells to model layers. Wells that lacked information to compute the top elevation of the open interval were assumed to be open to the top layer of the model. Wells that lacked information to compute the bottom elevation of the open interval were assumed to be open to the deepest layer of the model. Wells entirely within inactive cells were removed, resulting in 5,127 simulated withdrawal wells in the 5-layer models and 3,201 wells in the 1-layer model of the glacial aquifer system.

\section{Refinement of the Bedrock Surface}

Aquifer thickness is an important factor influencing the age of groundwater in an aquifer (Vogel, 1967). Given this study's ongoing objectives focused on groundwater ages in the glacial aquifer, proper representation of the glacial/bedrock contact was an important component of the model construction. A regional gridded bedrock surface extending below the glacial aquifer system (Soller, written commun., 2016) was initially used to represent the boundary between the glacial aquifers and the underlying bedrock aquifers in the models. However, during generation of the MNW2 package and creation of heterogeneous hydraulic conductivity fields (see the "Hydraulic Conductivity" section), local differences between the gridded surface and individual well construction reports were identified. To locally refine the bedrock surface and ensure proper functioning of the MNW2 package, the bedrock surface was modified within the FWP model domain using the following process:

Calculation of initial depth to bedrock.-Each cell in the model was intersected with a 10-meter resolution DEM (U.S. Geological Survey, 2014), and the mean elevation of the DEM within each model cell was assigned as the top elevation of the cell. For cells that contained a stream simulated with the SFR2 package or a water body simulated with the GHB 

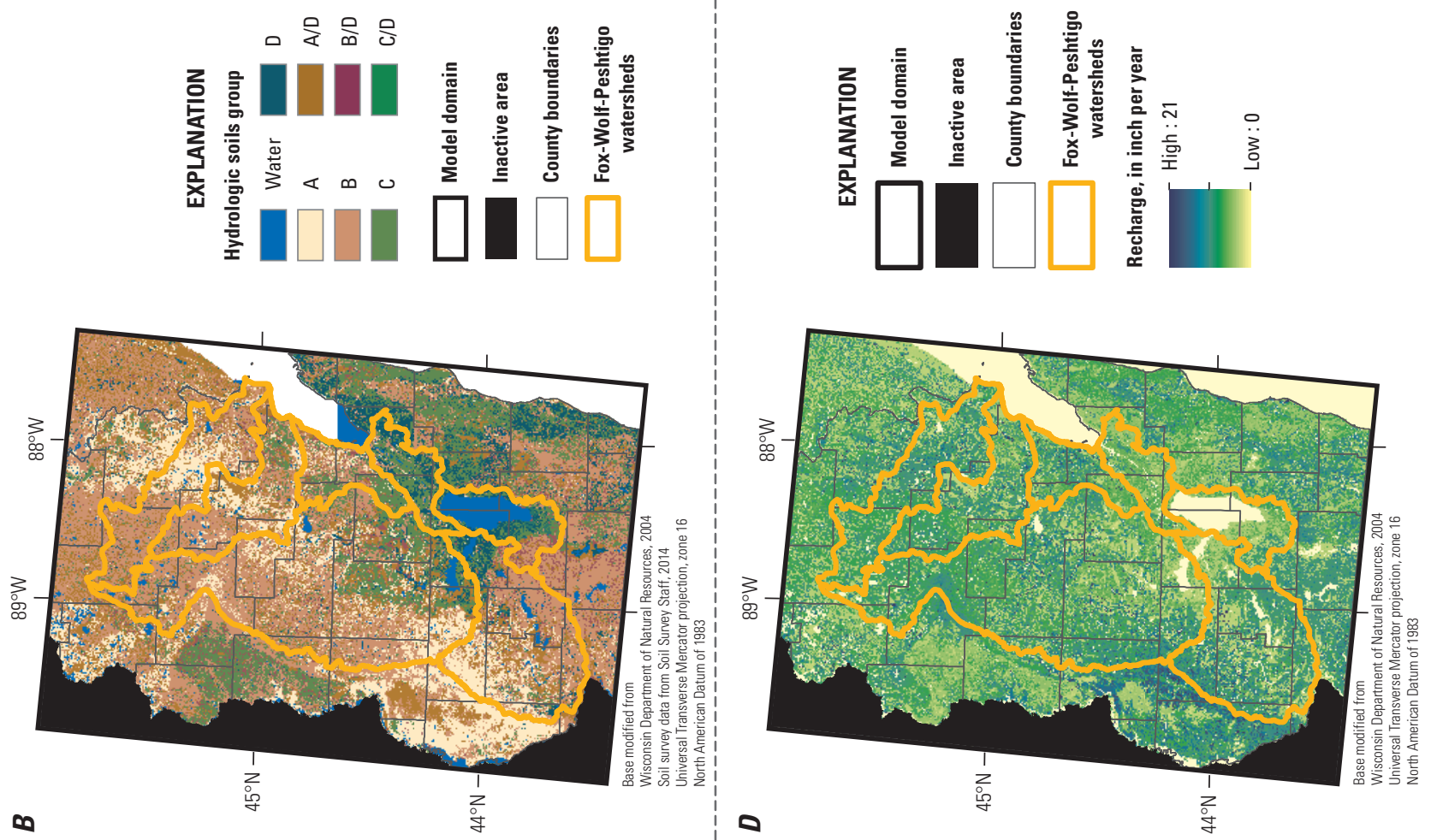

0
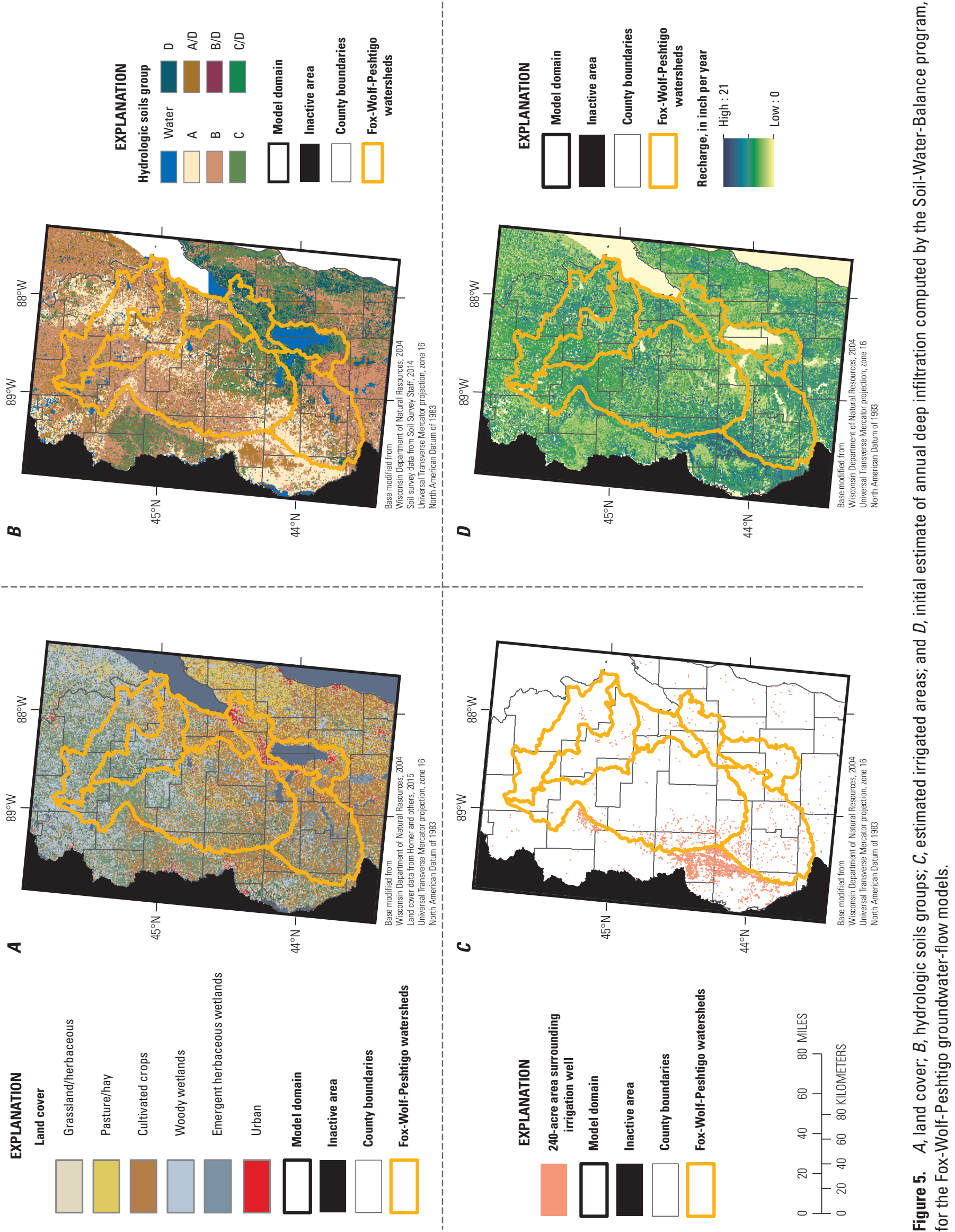
package, the top elevation was adjusted downward to match the streambed elevation or GHB elevation contained in the boundary package (see the "Surface-Water Network" section). Next, the bottom elevation at each cell center for the deepest glacial layer in each model was assigned the bedrock elevation at that location from the 1-kilometer resolution bedrock surface (Soller, written commun., 2016). Finally, the thickness of the glacial material, or depth to bedrock, was computed for each model cell as the difference between the model top elevation and the bottom elevation of the glacial deposits.

Calculation of depth to bedrock error.-Lithologic intervals described for wells in a standardized lithologic database (Arihood, 2009; Bayless and others, 2017) were binned into one of four lithologic codes, one of which represented bedrock (see the "Hydraulic Conductivity" section). After accounting for problematic unit descriptions described in the "Hydraulic Conductivity" section, the measured depth to bedrock reported for each well was compared with the depth to bedrock computed for the associated model cell. Each well was classified as the following: (a) the well contacted bedrock and the measured depth to bedrock was greater than that of the model, (b) the well contacted bedrock and the measured depth to bedrock was less than that of the model, (c) the well did not contact bedrock, but the well depth exceeded the depth to bedrock in the model, or (d) the well did not contact bedrock, and the well depth was less than the depth to bedrock in the model. Wells of class "a" and "c" indicated that the initial depth to bedrock in the model was too shallow; wells of class "b" indicated that the initial depth to bedrock in the model was too deep; wells of class "d" were inconclusive and were ignored for the remaining analysis. For cells that contained multiple wells, the mean difference between the measured depth to bedrock and that for the model cell was computed. A point feature class then was created for each model cell center and attributed with the mean difference, or error, for the depth to bedrock.

\section{Interpolation of depth to bedrock error.-A Simple} Kriging algorithm (Kitanidis, 1997) was used to interpolate the error in depth to bedrock from individual model cells that contained well logs to all cells across the model. A mean value of zero error was used for the Simple Kriging method, which ensured that initial depth to bedrock in the model was minimally adjusted, if at all, in areas with few or no well logs. The Simple Kriging method also used a nonzero value (computed as part of the algorithm) for the semivariogram nugget, which resulted in an inexact interpolation at cells with well logs (referred to as continuous part kriging by Kitanidis, 1997). Use of a nonzero nugget ensured that the resulting adjustment to the bedrock surface would account for the general spatial pattern in the bedrock error, but that the adjusted bedrock surface would not produce pinpoint agreement with individual well logs. This inexact interpolation was desirable because individual well logs can contain errors associated with their reported depths or location. Finally, the interpolated bedrock error was used to adjust the bedrock surface in the model.
Readjustment of the bedrock surface to match important wells.-The steps described previously were repeated for a smaller subset of wells, including high-capacity wells in the water use database (see the "Well Withdrawals" section) that was modified and updated from Feinstein and others (2010) and wells for which age tracer concentration samples had been collected (see the "Calibration Targets" section). This second adjustment of the bedrock surface included the following two key differences from the first adjustment: (1) the improved bedrock surface in the model from step 3 was used as the starting point for this analysis rather than the original surface by Soller (written commun., 2016), and (2) a value of zero for the semivariogram nugget was specified to ensure an exact interpolation whereby the measured depth to bedrock in cells with high-capacity wells or age tracer sampled wells would be matched exactly by the modeled bedrock surface. This second adjustment using an exact interpolator was necessary to ensure that high-capacity wells simulated with the MNW2 package did not extend below the bottom of the model (1-layer model case) and cause MODFLOW to halt execution. This step also improved the local aquifer characterization surrounding wells with age tracer concentrations, which was expected to affect simulated age distributions. Conducting this step as part of an interpolation, as opposed to forcing the bedrock surface deeper at individual well cells, ensured a smooth transition in the modeled bedrock surface from the well locations to surrounding cells. This final interpolation was used to update the bedrock surface, as represented by the model bottom in the 1-layer model and the bottom of layer 3 in the 5-layer models. The initial bedrock surface by Soller (written commun., 2016), as applied to the FWP model domain, and the updated bedrock surface at the culmination of step 4 is illustrated in figure 6 .

\section{Model Layering}

As described at the beginning of the "Model Construction" section, three MODFLOW models were constructed to simulate differing levels of aquifer complexity. The first model, a 1-layer model of glacial aquifer deposits used the refined bedrock surface to represent the base of the groundwater flow system (bedrock was not simulated). The second and third models used three layers to represent glacial deposits and two underlying layers to represent unconfined and confined bedrock aquifers. Converting the glacial deposits from one layer to three layers involved dividing the cell-by-cell thickness into three equal portions. The same refined bedrock surface was used to separate the base of the glacial aquifers (bottom of layer 3) from the underlying bedrock layers. The bottom elevations of each bedrock layer in the 5-layer models were derived from the corresponding bedrock layers in an "intermediate" LMB model described by Feinstein and others (2016). That is, layers 3 and 4 of the "intermediate" model by Feinstein and others (2016) became layers 4 and 5 of the two FWP models that simulated bedrock aquifers. Because the "intermediate" model by Feinstein and others (2016) used 


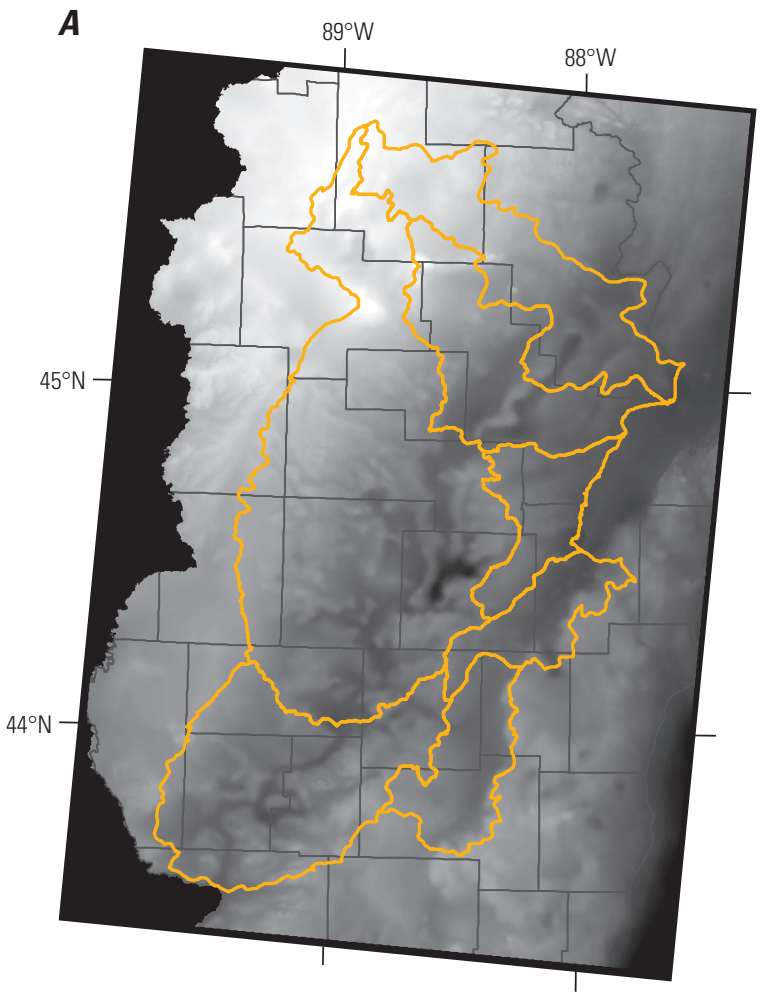

Base modified from Wisconsin Department of Natural Resources, 2004 Universal Transverse Mercator projection North American Datum of 1983
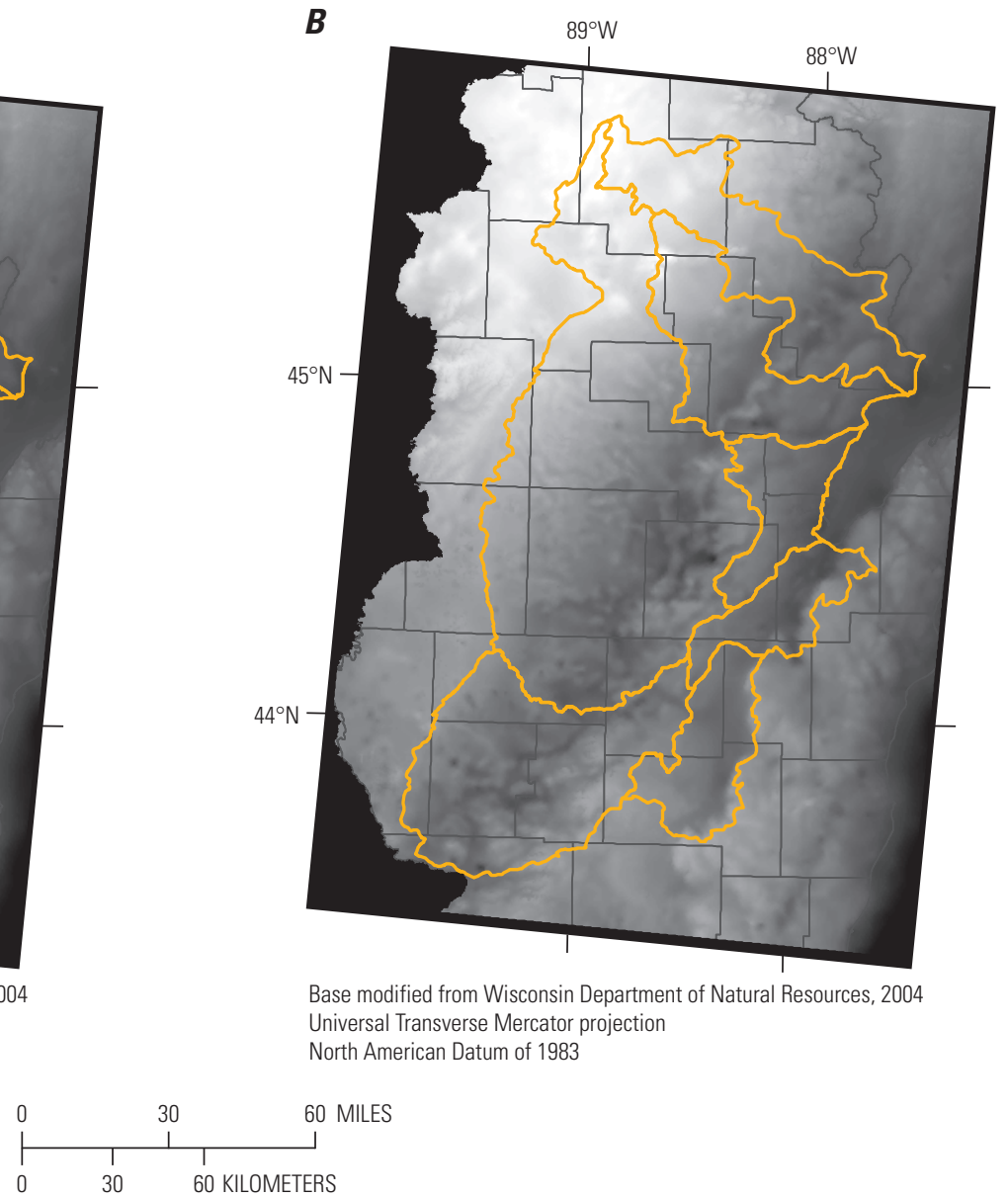

EXPLANATION

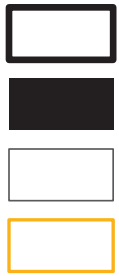

Model domain

Inactive area

County boundaries

Fox-Wolf-Peshtigo watersheds

Altitude, in feet above North American Vertical Datum of 1988

High : 1,735

Low : -116

Figure 6. A, The original bedrock elevation surface by Soller (written commun., 2016) and $B$, the final bedrock surface after adjusting for differences with measured depths to bedrock from well logs from the standardized lithologic database by Bayless and others (2017). 
cells that were much larger (fivefold longer along the row and column directions in the center; larger along the perimeter that includes much of the FWP model domain) than the 1,000-foot resolution FWP models, a Gaussian filter (Jones and others, 2001-16) was applied to smooth the layer bottoms in the FWP models. As described by Feinstein and others (2016), the upper bedrock layer in the FWP model represented unconfined bedrock aquifers; the lower bedrock layer represented confined bedrock, and the separating confining units were identified as units at least 5 -feet thick with a vertical hydraulic conductivity less than $0.001 \mathrm{ft} / \mathrm{d}$.

\section{Hydraulic Conductivity}

The ongoing objectives of the FWP study focus on evaluating differences in simulated groundwater flow and ages within the glacial aquifer system caused by adjusting model complexity. In addition to adjusting the number of layers used to represent aquifers, the level of complexity used to represent the permeability of glacial deposits was differed to facilitate evaluations of heterogeneity on simulated age distributions with future studies. Although hydraulic conductivity is not a component of the basic groundwater age calculation for a groundwatershed (mean aquifer age equals aquifer porosity times thickness divided by recharge; Vogel, 1967), Luther and Haitjema (1998) and Kozuskanich and others (2014) illustrated how heterogeneity can affect local groundwater ages. In particular, Luther and Haitjema (1998) and Kozuskanich and others (2014) noted that "significant and distinct" contrasts in hydraulic conductivity (through layering, lenses, or zonation) can substantially alter age distributions from idealized conditions. The magnitude of these local effects is an important consideration when evaluating simplifications likely to be invoked for larger-scale investigations of groundwater age across the glacial aquifer system.

This section describes the methods used to produce homogeneous zones and heterogeneous hydraulic conductivity patterns for the glacial aquifer model layers and bedrock hydraulic conductivity for the unconfined and confined aquifer layers of the models. The subsequent "Model Calibration" section describes how the initial hydraulic conductivity values were updated to better match observed values of water levels and stream base flows.

\section{Quaternary Deposits}

A stepped approach was developed as part of a software tool for representing hydraulic conductivity patterns in the glacial aquifers. First, generalized glacial categories were generated by simplification of quaternary geologic maps (Lineback and others, 1983; Farrand and others, 1984) collectively referred to as the Quaternary Geologic Atlas of the United States (accessed April 28, 2016, at https://gec.cr.usgs.gov/data/ quatatlas/index.shtml). The 1-layer model and one of the two 5-layer models used this simplified map of glacial categories to simulate internally homogenous hydraulic conductivity zones. These models will subsequently be referred to as the 1-layer zoned model and the 5-layer zoned model. For the second step, cell-by-cell heterogeneity was generated within each glacial category through interpolation of coarse fractions estimated from lithologic descriptions in well logs. The resulting heterogeneous hydraulic conductivity field was applied to the second 5-layer model, subsequently referred to as the 5-layer heterogeneous model.

The two digital copies of the Quaternary Atlas that covered the FWP study area in eastern Wisconsin (Lineback and others, 1983; Farrand and others, 1984) were joined and simplified to define glacial categories using a lookup table (table 2). The lookup table links the Quaternary Atlas map's "Geocode" attribute to nine glacial categories that are specific to the models described in this report but are expected to have some transferability to other areas with glacial deposits. The resulting glacial categories map (fig. 7) matched the generalized distribution of sand and gravel potential described by Hadley and Pelham (1976), but the method used by the software tool retains flexibility by allowing the modeler to choose how to group individual Geocodes into glacial categories. For example, to improve model calibration, loamy till deposits (Geocode "td") in the Quaternary Atlases were separated into either loamy or sandy till categories in table 2 , respectively, based on the associated type of moraine (ground or end moraine). This distribution resulted in more sandy tills in the Wolf River watershed compared with the Fox River watershed. No "undifferentiated material" (glacial category 8) occurred within the active part of the models. In addition, all areas mapped as water (glacial category 9) in the Quaternary Atlas were dissected using a Thiessen Polygon Method and changed from water to the closest adjacent glacial category to represent the glacial material beneath the water body. This change allowed for application of the glacial categories to multiple layers in the models and facilitated the use of boundary conditions to represent water bodies (see the "SurfaceWater Network" section) instead of hydraulic conductivity.

All three versions of the FWP model used the same glacial category map (fig. 7). A single hydraulic conductivity value was assigned to each glacial category in the zoned models, whereas distributions of coarse fractions were used along with the glacial category map to compute heterogeneous hydraulic conductivity fields for the 5-layer heterogeneous model.

After generating the glacial categories, a standardized lithologic database of well construction report records (Bayless and others, 2017) was used to develop heterogeneous hydraulic conductivity fields for the 5-layer heterogeneous version of the FWP model, using methods similar to those used by Faunt and others (2010), Feinstein and others (2010), and Feinstein and others (2012). That is, the internally homogeneous glacial category zones used in the 1-layer and 5-layer zoned models were replaced with a cell-by-cell heterogeneous hydraulic conductivity field that was created as a function of the glacial category zone and the spatial distribution of the 
Table 2. Association of Quaternary Atlas "Geocode" attribute codes with glacial categories.

[*, the "td" Geocode was further divided into glacial categories based upon the "Moraines" attribute in the Quaternary Atlas shapefile. Areas designated as ground moraines were assigned to glacial category 2; areas designated as end moraines were assigned to glacial category 3.]

\begin{tabular}{|c|c|c|}
\hline Quaternary Atlas "Geocode" & Glacial category number & Glacial category description \\
\hline ta, tac, tad, tc, th, tp, tx & 1 & Clayey till. \\
\hline $\mathrm{tb}, \mathrm{td}^{*}, \mathrm{tf}, \mathrm{tj}, \mathrm{tk}, \mathrm{tl}, \mathrm{tlp}, \mathrm{tlq}, \mathrm{tlr}, \mathrm{tm}, \mathrm{tn}, \mathrm{to}, \mathrm{tr}$ & 2 & Loamy till. \\
\hline $\mathrm{kg}, \mathrm{td}^{*}, \mathrm{tdb}, \mathrm{tde}, \mathrm{tdr}, \mathrm{tg}, \mathrm{tq}, \mathrm{ts}, \mathrm{tt}$ & 3 & Sandy till. \\
\hline bm, ea, eb, ee, el, la, lb, lc, lca, lg, lm, ln, lo, lp, ma, mc & 4 & Fine-grained stratified (glacial lake sediment). \\
\hline $\begin{array}{l}\text { ac, ag, ah, ak, ba, bb, bc, bd, ed, ex, gb, gc, gg, gk, gl, gs, } \\
\text { gt, ka, kd, ke, kf, km, lk, ls, lsa, mb, me, mh, ms }\end{array}$ & 6 & Coarse-grained stratified (glacial outwash). \\
\hline ha, hb, hc, hd, hd, hp, hs & 7 & Peat and other organic material. \\
\hline Island, lake, $\mathrm{R}, \mathrm{r}$, river, water & 9 & Water. \\
\hline
\end{tabular}

glacial material's "coarse fraction" as inferred from well log intervals. The method involved the following six primary steps:

1. Categorize lithologic descriptions according to their coarseness. - Unit descriptions in the standardized lithology database, which correspond to 91 Groundwater Site Inventory (GWSI) descriptors (Mathey, 1989; Arihood, 2009), were paired with one of four lithologic codes representing bedrock $(0)$, primarily coarse-grained material (1), mixed fine and coarse-grained material (2), and primarily fine-grained material (3) in a lookup table (table 3) and saved to a geodatabase. Lithologic intervals for each well that indicated the presence of bedrock were removed, as were any intervals that contained the GWSI code "OTHR" or the deepest interval of a well log that contained the GWSI code "BLDR". Detailed inspection and comparison with a depth to bedrock surface by Soller (written commun., 2016) illustrated a consistent pattern in which well logs incorrectly described the first bedrock contact as "BLDR", or boulders, in certain counties within the model area. Removal of this miscategorized interval was necessary to ensure proper identification of the bedrock surface in the central part of the FWP model domain (see the "Refinement of the Bedrock Surface" section).
2. Match well log intervals to model cells and layers.Each well log interval then was assigned to a specific model cell for each layer in the 5-layer heterogeneous model. Specifically, the spatial location of each well in the standardized lithology geodatabase was intersected with the model grid to identify the row and column of the associated model cell. Next, problematic well log intervals were removed. Problematic intervals included the following: (a) logs for which the top interval was bedrock, (b) logs that contained a gap in the depth between intervals, (c) logs that contained repeated intervals, and (d) logs in which the depth to the top of the interval was reported as being larger than the depth to the bottom of the interval.

The remaining log intervals were then matched with model layers. First, log intervals were collapsed such that only the thickness of log intervals below the measured water table (saturated lithology) and above the bottom depth of the lower-most glacial aquifer were considered. Log intervals above the water table were considered to represent the unsaturated part of the aquifer and, therefore, shortened to account for only the saturated part of the log interval. A maximum depth-to-water limit was applied to all well $\operatorname{logs}$ to ensure that erroneously 


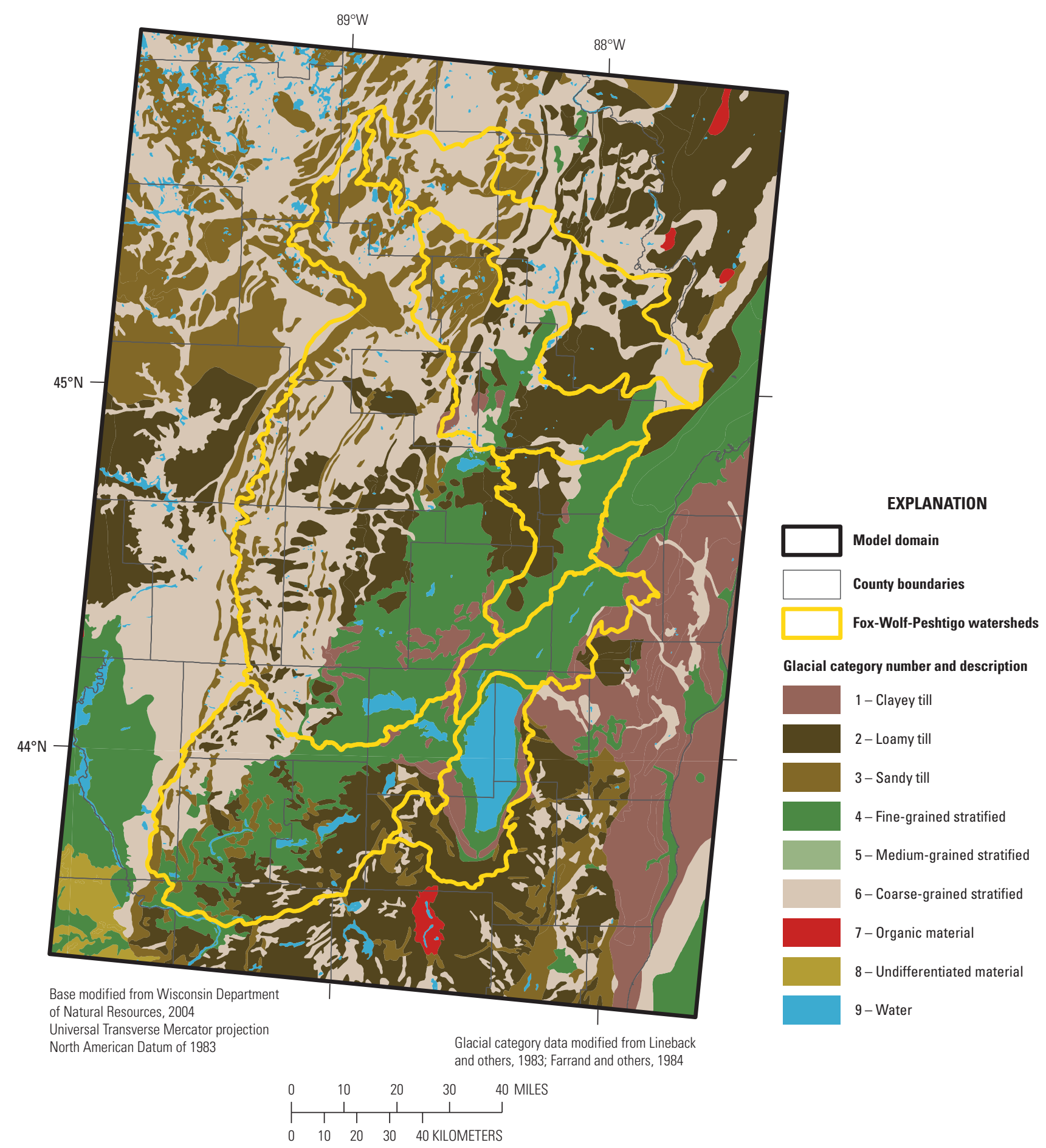

Figure 7. Glacial categories used to represent hydraulic conductivity zones or to relate coarse fractions to heterogeneous hydraulic conductivity values in the Fox-Wolf-Peshtigo groundwater-flow models. 
deep entries of depth to water did not unduly diminish individual log intervals. A maximum depth-to-water limitation of 50 feet was used because measurements of depth to water immediately following well drilling can be spurious, and local knowledge of the area suggested that the water table is usually within about 50 feet of the land surface through most of the FWP model area. Log intervals that described unconsolidated glacial deposits that reached greater depths than the bottom of the deepest glacial layer in the model were collapsed such that the intervals were halted at the base of the deepest glacial model layer. This difference between the depth of glacial deposits described by well logs and the depth represented with the initial model layers were used to compute the mean bedrock elevation error for each model cell and exported to a separate geodatabase that was used to improve the bedrock surface in the model (see the "Refinement of the Bedrock Surface" section). Because of this iterative step, the algorithms described earlier were initially run up to this point, the bedrock surface was updated in the model, and the method described in this section was repeated. Finally, log intervals were assigned to specific model layers only if the well log penetrated to bedrock or if the well log spanned at least 50 percent of the associated layer thickness. The resulting geodatabase of cell-by-cell based glacial lithologic descriptions occupied approximately 12 percent of all cells in the model.

3. Compute weighted-coarse fractions for cells containing logs.-All log intervals within a single model cell were assigned a thickness-weighted coarse fraction and were combined with other well log intervals in the same cell to compute a mean coarse fraction for each cell. The thickness of each log interval within a model cell was computed by the depths of the top and bottom of the interval between the model cell top and bottom. The thickness of each log interval within a model cell then was multiplied by the estimated coarse fraction $(0$, 35 , or 100 percent) associated with the coarseness code for the log interval, as defined in table 3 , to compute a thickness-weighted coarse fraction for the log interval. A tertiary distribution of coarse fraction was used whereby log intervals identified as containing coarsegrained lithologic descriptors were assumed to contain 100 percent coarse-grained material, intervals with mixed lithologic descriptors were assumed to contain 35 percent coarse-grained material, and intervals with finegrained lithologic descriptors were assumed to contain zero percent coarse-grained material. The composite thickness-weighted coarse fraction for each cell was computed by dividing the total weighted coarse fraction of all $\log$ intervals within a cell by the total thickness of $\log$ intervals within the cell. Finally, for cells that contained at least one well log, the Cartesian coordinates of the model cell center and the associated composite coarse fraction values were exported to a geodatabase (fig. 8). Each glacial layer of the model was exported as a separate feature in the geodatabase.

4. Interpolation of coarse fractions for glacial layers.Coarse fraction values were computed for every cell in a model layer through spatial interpolation by kriging values for cells with coarse fractions computed from the methods described earlier (fig. 9). Ordinary kriging with a linear semivariogram was chosen rather than other methods, such as inverse distance weighting, because kriging is less prone to overfitting individual data points (fewer "bullseyes"). Summary statistics, such as the minimum, mean, and maximum coarse fraction for all cells within individual glacial categories are listed in table 4. In general, the mean coarse fraction increased from finer-grained glacial categories (categories 1 and 4) to coarser-grained glacial categories (categories 3 and 6), as was expected. Also, the mean coarse fraction seemed to be uniform or perhaps slightly decreased with depth in several of the glacial categories, which could affect the relation between simulated groundwater ages and aquifer depths (Luther and Haitjema, 1998) in subsequent evaluations.

\section{Relate coarse fraction to hydraulic conductivity.-A} relation was established between the minimum, mean, and maximum coarse fractions for all model cells within a glacial category and an estimated minimum, expected, and maximum horizontal hydraulic conductivity (hk) using a lookup table (table 5). The Python language's Scipy library (Jones and others, 2001-16), specifically the curve_fit function from Scipy's Optimize module, was used to fit a curve through the three ratios of coarse fraction to hydraulic conductivity for each glacial category. Equations for exponential, log-linear, and linear interpolation were sequentially optimized to fit the data. The first of the three sequentially tested equations to produce a sum of squared residuals less than 1.0 was selected as the best fit equation for interpolating hydraulic conductivity values from the range of coarse fraction values in all model cells within a glacial category. If coefficients for the exponential or log-linear equations could not be computed by the curve_fit function, the linear equation was selected by default. An example of a best-fit curve for an exponential equation defining the relation between coarse fraction and hydraulic conductivity for the sandy till glacial category in layer 1 of the 5-layer heterogeneous model is shown in figure 10 . Because the glacial categories were assumed to represent the full thickness of glacial deposits and, thus, applied to all three glacial layers of the model, the computed mean coarse fraction for layers 2 and 3 were changed to the mean coarse fraction computed for layer 1 in the lookup table for each glacial category (table 5). That is, the same fitted interpolation equation relating coarse fraction to hydraulic conductivity in each glacial category was 
applied to all three glacial layers of the 5-layer heterogeneous model.

6. Compute hydraulic conductivity for each "glacial" model cell.-Finally, cell-by-cell values of horizontal hydraulic conductivity were computed for the model. Initial estimates of hydraulic conductivity were applied based on values used by Feinstein and others (2010) for the LMB model. Final hydraulic conductivity values were computed during the calibration process by adjusting the minimum, expected, and maximum hydraulic conductivity values for each glacial category, as described in the "Model Calibration" section.
The multilayer models required additional parameterization for vertical hydraulic conductivity in the glacial layers. Vertical hydraulic conductivity in the glacial layers was specified in the model as an anisotropy ratio (vani) computed by dividing the horizontal hydraulic conductivity by an estimated vertical hydraulic conductivity for each glacial category. That is, for the 5-layer zoned model and the 5-layer heterogeneous model, one horizontal to vertical hydraulic conductivity ratio, or vani value, was estimated for each glacial category. Because horizontal hydraulic conductivity varied spatially in the 5-layer heterogeneous model, vertical hydraulic conductivity values that were used internally by MODFLOW also varied spatially by cell, even though a single vani value was specified per glacial category. Final vani values were computed during the calibration process (see the "Model Calibration" section).

Table 3. Association of Groundwater Site Inventory descriptors with coarseness codes used to compute coarse fractions for model cell nodes.

[GWSI, Groundwater Site Inventory; --, no data; *, refer to the text for an explanation of why well log intervals with GWSI descriptors "boulders" were designated as bedrock]

\begin{tabular}{llccc}
\hline \multicolumn{1}{c}{$\begin{array}{c}\text { GWSI lithologic } \\
\text { descriptor }\end{array}$} & GWSI lithologic code & Coarseness code & $\begin{array}{c}\text { Coarseness code } \\
\text { description }\end{array}$ & $\begin{array}{c}\text { Estimated coarse } \\
\text { fraction (percent) }\end{array}$ \\
\hline anhydrite & ANDR & 0 & Bedrock & - - \\
\hline anorthsite & ANRS & 0 & Bedrock & - \\
\hline arkose & ARKS & 0 & Bedrock & - - \\
\hline basalt & BSLT & 0 & Bedrock & - \\
\hline bentonite & BNTN & 0 & Bedrock & - \\
\hline breccia & BRCC & 0 & Bedrock & - \\
\hline calcite & CLCT & 0 & Bedrock & - \\
\hline caliche & CLCH & 0 & Bedrock & - \\
\hline chalk & CHLK & 0 & Bedrock & - \\
\hline chert & CHRT & 0 & Bedrock & - \\
\hline claystone & CLSN & 0 & Bedrock & - \\
\hline coal & COAL & 0 & Bedrock & - \\
\hline conglomerate & CGLM & 0 & Bedrock & - \\
\hline coquina & CQUN & 0 & Bedrock & - \\
\hline diabase & DIBS & 0 & Bedrock & - \\
\hline diorite & DORT & 0 & Bedrock & - \\
\hline dolomite & DLMT & 0 & Bedrock & - \\
\hline dolomite_shale & DMSH & 0 & Bedrock & - \\
\hline evaporite & EVPR & 0 & Bedrock & - \\
\hline gabbro & GBBR & 0 & Bedrock & - \\
\hline gneiss & GNSS & 0 & Bedrock & - \\
\hline granite & GRNT & 0 & Bedrock & - \\
\hline granite_gneiss & GRGN & 0 & Bedrock & - \\
\hline gravel_cemented & GRCM & 0 & Bedrock & - \\
\hline greenstone & GNST & 0 & Bedrock & - \\
\hline & & & & - \\
\hline
\end{tabular}


Table 3. Association of Groundwater Site Inventory descriptors with coarseness codes used to compute coarse fractions for model cell nodes.-Continued

[GWSI, Groundwater Site Inventory; --, no data; *, refer to the text for an explanation of why well log intervals with GWSI descriptors "boulders" were designated as bedrock]

\begin{tabular}{|c|c|c|c|c|}
\hline $\begin{array}{l}\text { GWSI lithologic } \\
\text { descriptor }\end{array}$ & GWSI lithologic code & Coarseness code & $\begin{array}{c}\text { Coarseness code } \\
\text { description }\end{array}$ & $\begin{array}{l}\text { Estimated coarse } \\
\text { fraction (percent) }\end{array}$ \\
\hline greywacke & GRCK & 0 & Bedrock & -- \\
\hline gypsum & GPSM & 0 & Bedrock & -- \\
\hline igneous & IGNS & 0 & Bedrock & -- \\
\hline lignite & LGNT & 0 & Bedrock & -- \\
\hline limestone & LMSN & 0 & Bedrock & -- \\
\hline limestone_dolomite & LMDM & 0 & Bedrock & -- \\
\hline limestone_shale & LMSH & 0 & Bedrock & -- \\
\hline marble & MRBL & 0 & Bedrock & -- \\
\hline marlstone & MRLS & 0 & Bedrock & -- \\
\hline metamorphic & MMPC & 0 & Bedrock & -- \\
\hline mudstone & MDSN & 0 & Bedrock & -- \\
\hline quartzite & QRTZ & 0 & Bedrock & -- \\
\hline residium & RSDM & 0 & Bedrock & -- \\
\hline rhyolite & RYLT & 0 & Bedrock & -- \\
\hline rock & ROCK & 0 & Bedrock & -- \\
\hline sandstone & SNDS & 0 & Bedrock & -- \\
\hline sandstone_shale & SDSL & 0 & Bedrock & -- \\
\hline saprolite & SPRL & 0 & Bedrock & -- \\
\hline schist & SCST & 0 & Bedrock & -- \\
\hline sedimentary & SDMN & 0 & Bedrock & -- \\
\hline serpentine & SRPN & 0 & Bedrock & -- \\
\hline shale & SHLE & 0 & Bedrock & -- \\
\hline siltstone & SLSN & 0 & Bedrock & -- \\
\hline siltstone_shale & SLSH & 0 & Bedrock & -- \\
\hline slate & SLTE & 0 & Bedrock & -- \\
\hline syenite & SYNT & 0 & Bedrock & -- \\
\hline travertine & TRVR & 0 & Bedrock & -- \\
\hline tuff & TUFF & 0 & Bedrock & -- \\
\hline volcanic & VLCC & 0 & Bedrock & -- \\
\hline Boulders * & BLDR & 0 & Bedrock & -- \\
\hline other & OTHR & -1 & Ignored & -- \\
\hline boulders_sand & BLSD & 1 & Coarse & 100 \\
\hline cobbles & COBB & 1 & Coarse & 100 \\
\hline cobbles_sand & COSD & 1 & Coarse & 100 \\
\hline gravel & GRVL & 1 & Coarse & 100 \\
\hline outwash & OTSH & 1 & Coarse & 100 \\
\hline rubble & RBBL & 1 & Coarse & 100 \\
\hline sand & SAND & 1 & Coarse & 100 \\
\hline sand_gravel & SDGL & 1 & Coarse & 100 \\
\hline
\end{tabular}


Table 3. Association of Groundwater Site Inventory descriptors with coarseness codes used to compute coarse fractions for model cell nodes.-Continued

[GWSI, Groundwater Site Inventory; --, no data; *, refer to the text for an explanation of why well log intervals with GWSI descriptors "boulders" were designated as bedrock]

\begin{tabular}{|c|c|c|c|c|}
\hline $\begin{array}{l}\text { GWSI lithologic } \\
\text { descriptor }\end{array}$ & GWSI lithologic code & Coarseness code & $\begin{array}{c}\text { Coarseness code } \\
\text { description }\end{array}$ & $\begin{array}{l}\text { Estimated coarse } \\
\text { fraction (percent) }\end{array}$ \\
\hline alluvium & ALVM & 2 & Mixed & 35 \\
\hline boulders_silt_clay & BLSC & 2 & Mixed & 35 \\
\hline clay_some_sand & CLSD & 2 & Mixed & 35 \\
\hline cobbles_silt_clay & COSC & 2 & Mixed & 35 \\
\hline colluvium & CLVM & 2 & Mixed & 35 \\
\hline drift & DRFT & 2 & Mixed & 35 \\
\hline glacial & GLCL & 2 & Mixed & 35 \\
\hline gravel_clay & GRCL & 2 & Mixed & 35 \\
\hline gravel_sand_silt & GRDS & 2 & Mixed & 35 \\
\hline gravel_silt_clay & GRSC & 2 & Mixed & 35 \\
\hline loam & LOAM & 2 & Mixed & 35 \\
\hline loess & LOSS & 2 & Mixed & 35 \\
\hline overburden & OBDN & 2 & Mixed & 35 \\
\hline peat & PEAT & 2 & Mixed & 35 \\
\hline sand_clay & SDCL & 2 & Mixed & 35 \\
\hline sand_gravel_clay & SGVC & 2 & Mixed & 35 \\
\hline sand_silt & SDST & 2 & Mixed & 35 \\
\hline sand_some_clay & SNCL & 2 & Mixed & 35 \\
\hline soil & SOIL & 2 & Mixed & 35 \\
\hline clay & CLAY & 3 & Fine & 0 \\
\hline hardpan & HRDP & 3 & Fine & 0 \\
\hline marl & MARL & 3 & Fine & 0 \\
\hline muck & MUCK & 3 & Fine & 0 \\
\hline mud & MUD & 3 & Fine & 0 \\
\hline silt & SILT & 3 & Fine & 0 \\
\hline silt_clay & STCL & 3 & Fine & 0 \\
\hline till & TILL & 3 & Fine & 0 \\
\hline
\end{tabular}




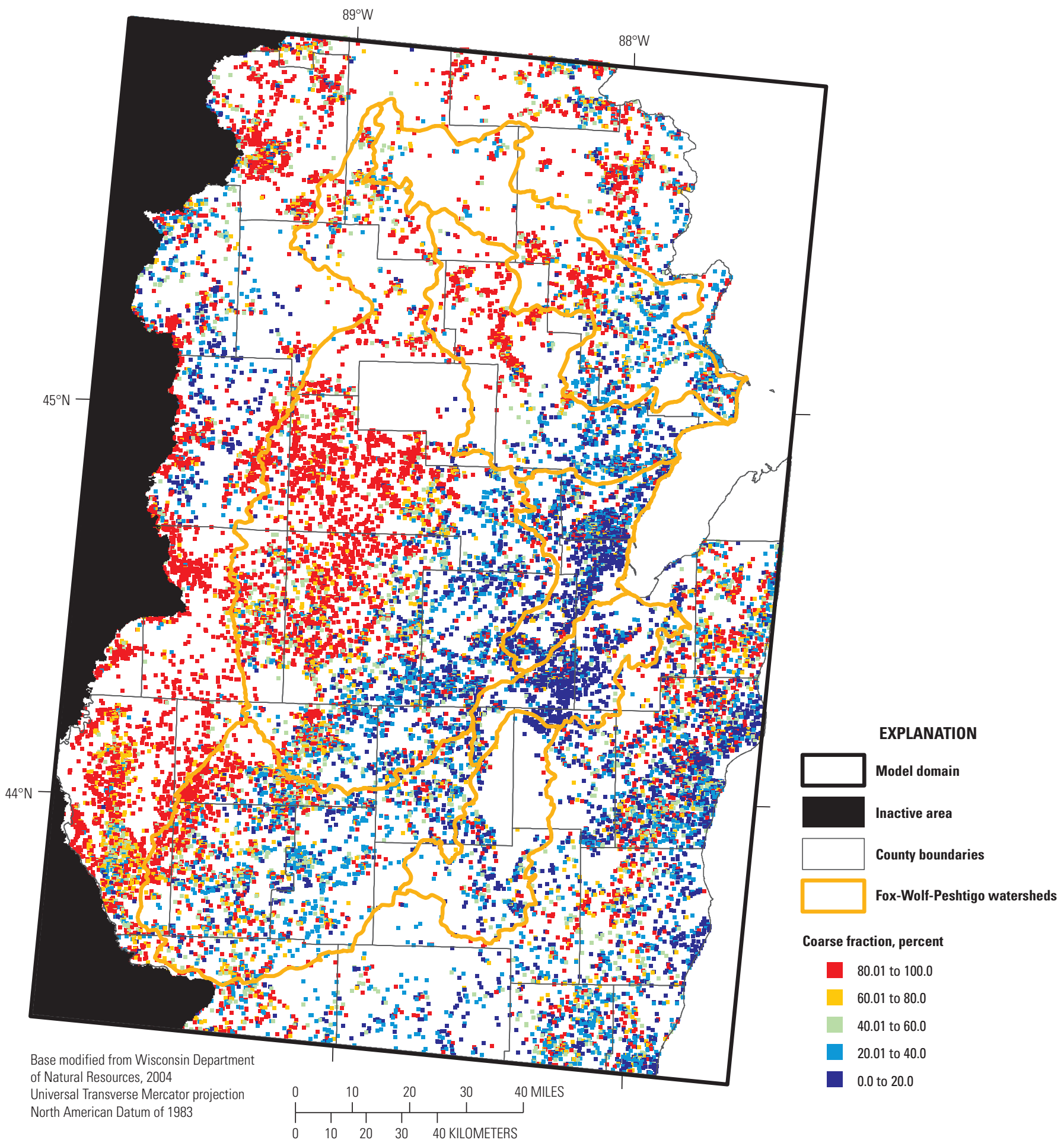

Figure 8. Composite coarse fraction for model cells that contain lithologic logs from the standardized lithologic database by Bayless and others (2017). 


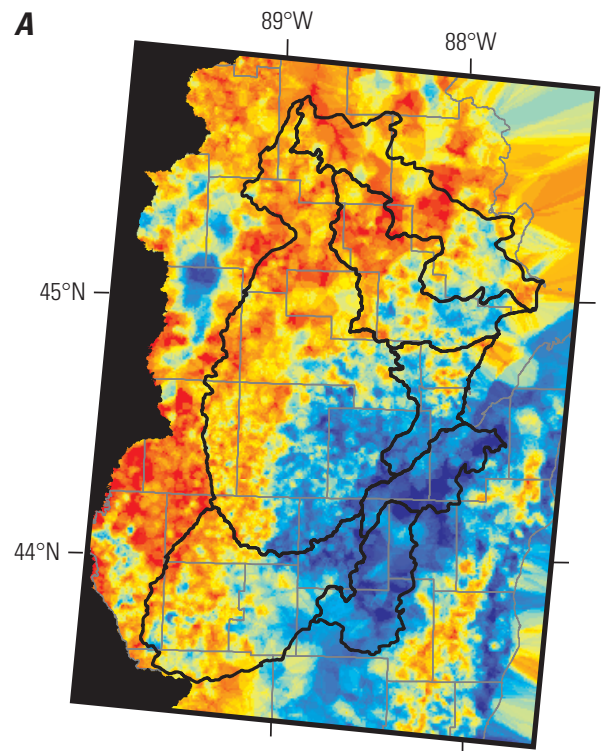

Base modified from Wisconsin Department of Natural Resources, 2004

Universal Transverse Mercator projection

North American Datum of 1983
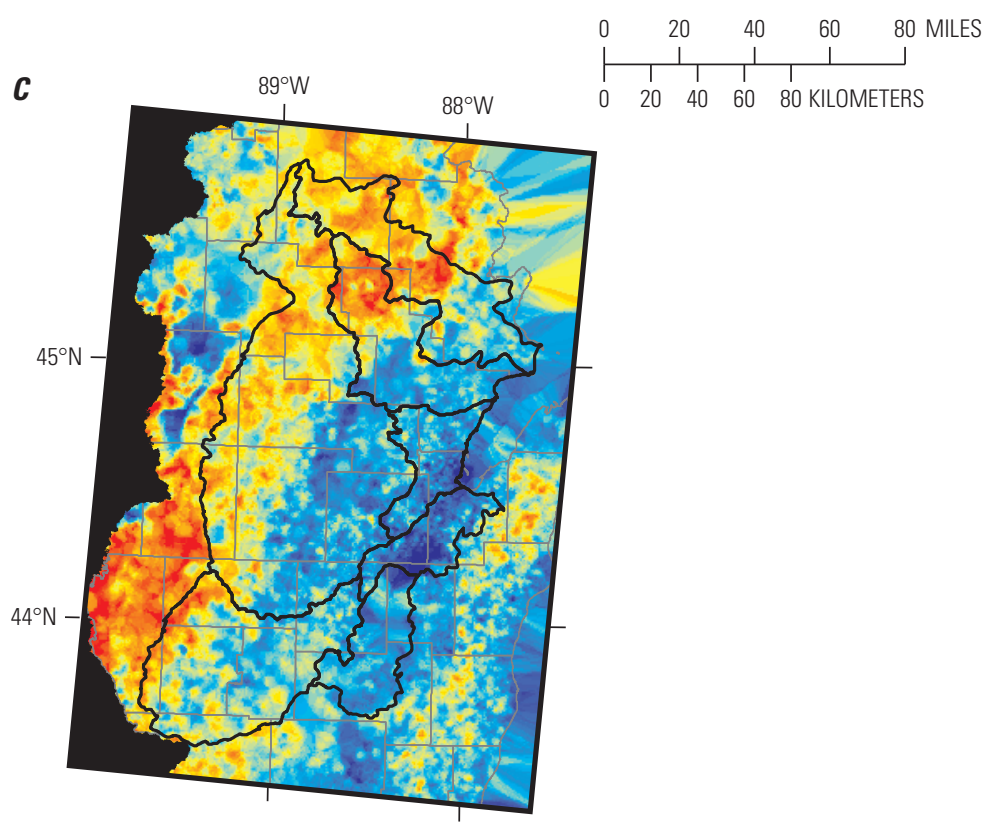

Base modified from Wisconsin Department

of Natural Resources, 2004

Universal Transverse Mercator projection

North American Datum of 1983

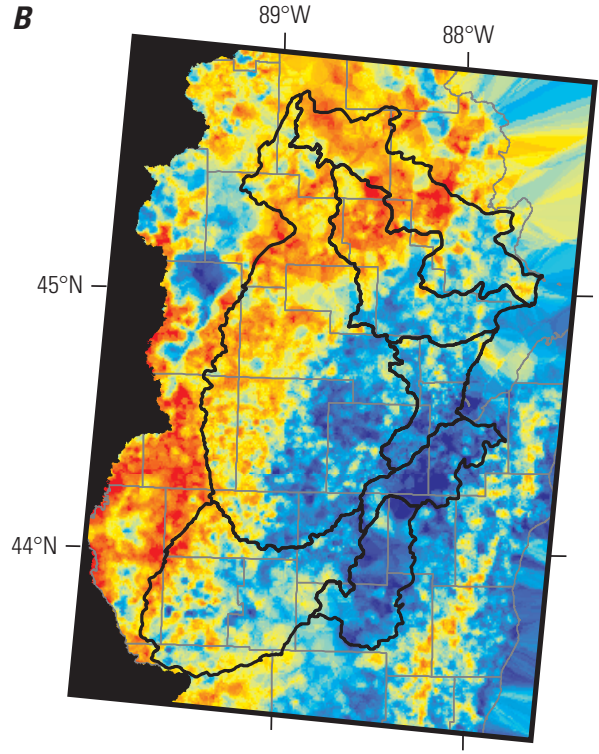

Base modified from Wisconsin Department

of Natural Resources, 2004

Universal Transverse Mercator projection

North American Datum of 1983

Figure 9. Cell-by-cell coarse fraction for glacial deposits in the 5-layer heterogeneous model in $A$, layer $1 ; B$, layer 2; and $C$, layer 3. 
Table 4. Summary statistics for the coarse fraction computed for each glacial category by glacial model layer.

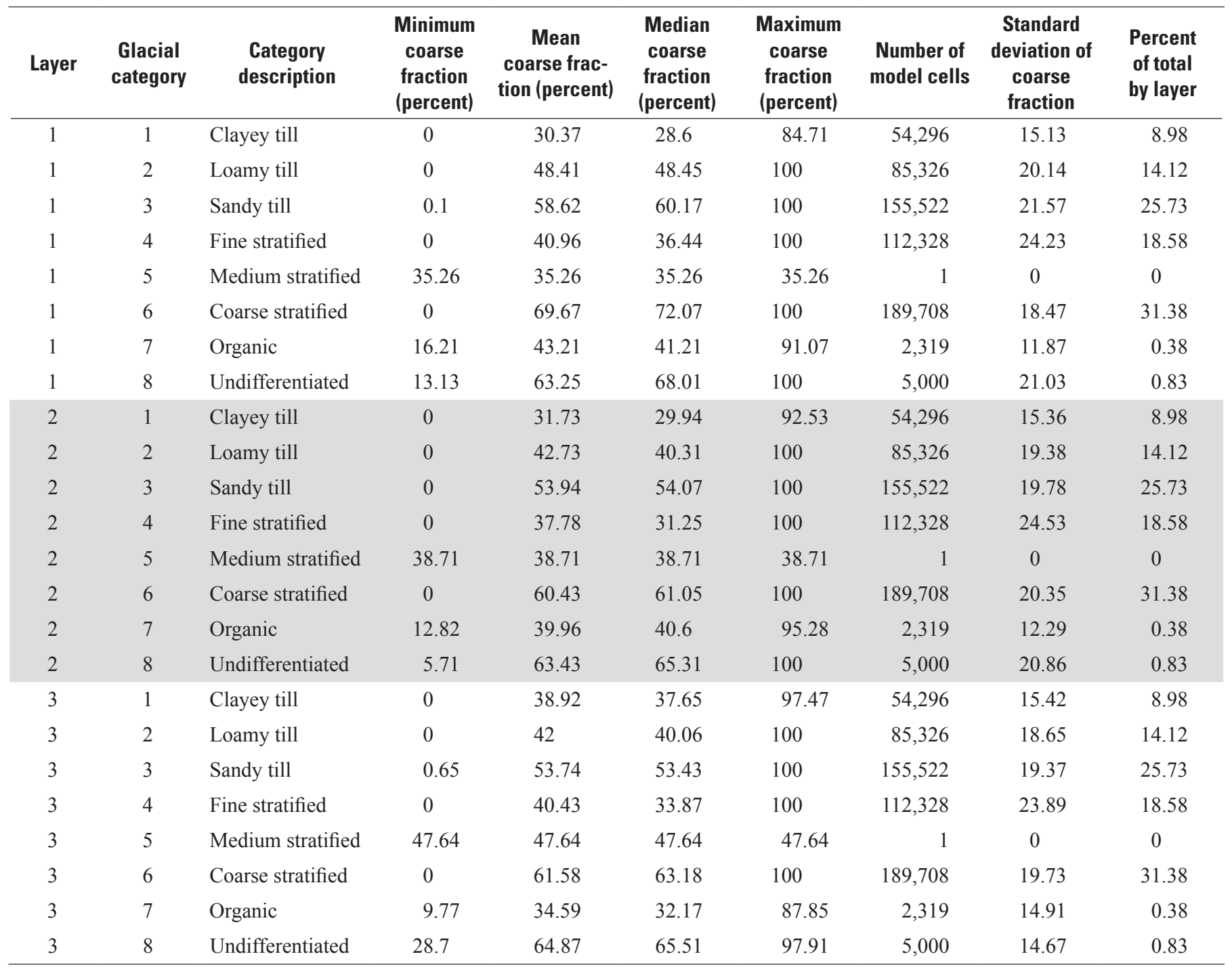

Table 5. Computed minimum, mean, and maximum coarse fraction for each glacial category in each glacial model layer and associated initial estimates of minimum, expected, and maximum horizontal hydraulic conductivity. Initial hydraulic conductivity estimates were based on Feinstein and others (2010).

[minCoarse, minimum coarse fraction; meanCoarse, mean coarse fraction; maxCoarse, maximum coarse fraction; Min_hk, minimum horizontal hydraulic conductivity; ft/d, foot per day; Exp_hk, expected horizontal hydraulic conductivity; Max_hk, maximum horizontal hydraulic conductivity]

\begin{tabular}{cccccccc}
\hline Layer & Category & minCoarse & meanCoarse & maxCoarse & Min_hk (ft/d) & Exp_hk (ft/d) & Max_hk (ft/d) \\
\hline $1-3$ & 1 & 0 & 0.30 & 1 & 1 & 5 \\
$1-3$ & 2 & 0 & 0.48 & 1 & 2.7 & 13.5 \\
$1-3$ & 3 & 0 & 0.59 & 1 & 3.3 & 16.3 \\
$1-3$ & 4 & 0 & 0.41 & 1 & 1.1 & 5.5 \\
$1-3$ & 5 & 0 & 0.35 & 1 & 30.2 & 151 \\
$1-3$ & 6 & 0 & 0.70 & 1 & 30.2 & 151 \\
$1-3$ & 7 & 0 & 0.43 & 1 & 2.7 & 400 \\
$1-3$ & 8 & 0 & 0.63 & 2.7 & 13.5 & 13.5 \\
\hline
\end{tabular}




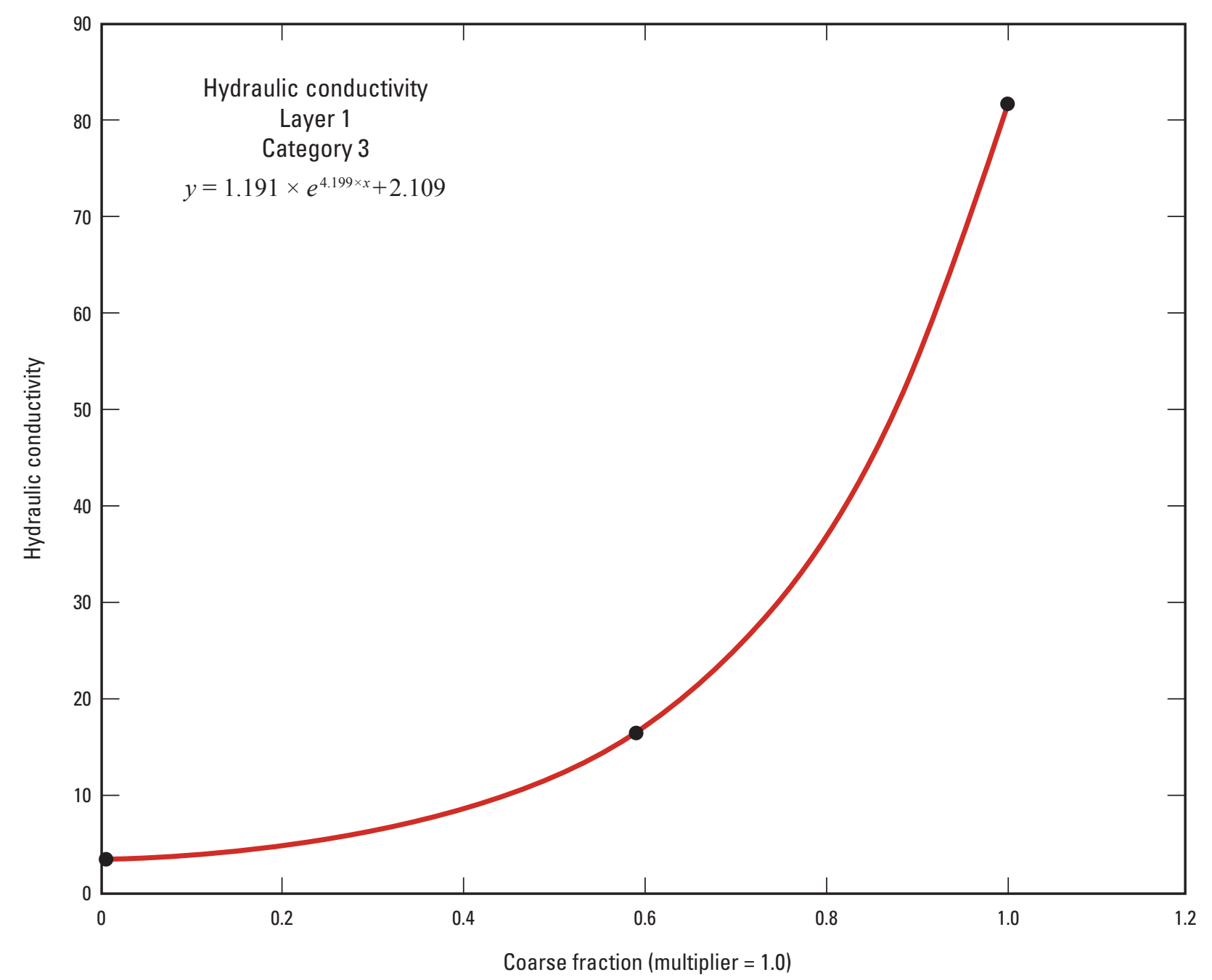

Figure 10. Example graph showing a fitted exponential interpolation through points associating minimum, mean, and maximum coarse fraction with initial estimates of minimum, expected, and maximum hydraulic conductivity for the sandy till glacial category in layer 1 of the 5-layer heterogeneous model.

\section{Bedrock Hydraulic Conductivity}

Similar to bottom elevations for bedrock layers, the horizontal and vertical hydraulic conductivities used to represent bedrock aquifers in the 5-layer models were derived from the corresponding bedrock layers in an "intermediate" LMB model described by Feinstein and others (2016). That is, hydraulic conductivity in layers 3 and 4 of the "intermediate" model by Feinstein and others (2016) was transferred to layers 4 and 5 of the two 5-layer models. Because the "intermediate" model used cells that were much larger $(5,000$-foot resolution or larger) than the 1,000-foot resolution of FWP models, a Gaussian filter (Jones and others, 2001-16) was applied to smooth the horizontal and vertical hydraulic conductivity values in the FWP models.

\section{Model Calibration}

Model calibration is the process by which initial input values (for example, hydraulic conductivity) are adjusted to improve the match between simulated outputs (water levels and base flows) and corresponding field measurements, or targets. Working from the simplest to most complex, each FWP model was independently calibrated using the parameter estimation code, PEST (Doherty, 2010), which algorithmically seeks to minimize the difference between simulated and measured target values by adjusting parameter values within user-specified limits. More specifically, the sum of the squared-weighted residuals between simulated and measured target values (PHI) is minimized by PEST during the 
calibration. The target weighting process provides a means to account for variable measurement accuracies among individual targets as well as a means to account for differences in the magnitude of residuals because of the units of measure (water levels reported in feet compared with base flows reported in cubic feet per day). An advantage of using a parameter estimation code is that in addition to computing the best fit to targets, the code provides insight into which parameters most strongly affect the groundwater flow system, as represented by the target water levels and base flows. This parameter sensitivity information, along with parameter correlations computed by PEST, was automatically incorporated into the calibration in that PEST was setup to use singular value decomposition (SVD; Doherty and Hunt, 2010; Doherty, 2010; Doherty, 2015) so that only the most sensitive parameters were updated during calibration, whereas insensitive parameters remained near their initial values. A value of $5 \times 10^{-5}$ was used for the SVD truncation threshold for all FWP models, which is within the range suggested by Doherty and Hunt (2010). Doherty and Hunt (2010) provided a more in-depth discussion and suggestions for proper application of parameter estimation using SVD and other techniques; an in-depth discussion of the theory and mathematical application of SVD and other methods available in PEST are provided in Doherty (2015).

\section{Calibration Targets}

The FWP models were calibrated to 200 long-term (1970-99) base-flow targets and several thousand waterlevel targets (fig. 11). All three models were calibrated to the same set of targets, except that the 5-layer models also were calibrated to water levels from wells open to bedrock aquifers. The 1-layer model was limited to water-level targets open only to the glacial aquifer that did not seem affected by vertical gradients, which cannot be simulated with a 1-layer model.

Base-flow targets were derived from Gebert and others (2011) and consisted of 34 multiyear U.S. Geological Survey (USGS) continuous-recording gaging stations and 166 USGS partial-record stations. Target base-flow values for gaging stations were computed by Gebert and others (2011) for 1970-99 using a Base-Flow Index method (Institute of Hydrology, 1980a, 1980b), as implemented by (Wahl and Wahl, 1995). For gaging stations with considerably less than 30 -years of record, Gebert and others (2011) extended the base-flow record by relating the overlapping period of record with a nearby index gage possessing a record for the full 30 -year period. Target base-flow values for partial-record stations were computed using a regression line that related low-flow discharge measurements at the partial-record station with discharge on the same day at an index station. For cases in which this relation-line approach produced unreasonable estimates of annual base flow, Gebert and others (2011) used a statewide regression equation that incorporated watershed areas and the 90-percent flow duration at the index station. Only gaging stations and partial-record stations with a minimum target base flow of 10 cubic feet per second $\left(\mathrm{ft}^{3} / \mathrm{s}\right)$ were used to calibrate the FWP models. Weight for each base-flow target was estimated according to the type of target (gage or partial-record station) and the amount of flow so that both small and large streams would affect the calibration. Specifically, weights were computed by using a 95-percent confidence level (Hill, 1998) in which target values for gaging stations were expected to be within 2 percent of the "true" multiyear base-flow, and target values for partial-record stations were expected to be within 10 percent of the "true" base flow 95 percent of the time. That is, the 95-percent confidence level and expected accuracy were used to compute a standard deviation based on a normal curve (Davis, 1986). Weights were then computed as the inverse of the estimated coefficient of variation (standard deviation divided by the target value). Subsequent to this initial measurement-error approach for computing weights, the calibration process revealed that small flux targets had more effect on the calibration than desired because of the abundance of small flux targets; therefore, weights for base-flow targets between 150 and $599 \mathrm{ft}^{3} / \mathrm{s}$ were doubled, and weights for baseflow targets above $600 \mathrm{ft}^{3} / \mathrm{s}$ were increased sixfold.

Water-level targets were derived from the USGS National Water Information System (NWIS) database (Dempster, 1990) and the Wisconsin Department of Natural Resource's well construction reports database (Wisconsin Department of Natural Resources, 2014). The wells obtained from the USGS NWIS were included as targets if water levels had been measured at least twice between 1970 and 2012, or the well was associated with one of the NAWQA networks focused on the glacial aquifer, as listed in table 6. Wells in these NAWQA networks were of direct interest for this study because most wells had been sampled for age tracers and were expected to be of interest for future evaluations with the FWP models. The resulting dataset consisted of 277 water-level targets from wells in the USGS NWIS and 8,772 water-level targets from well-construction reports used to calibrate the 5-layer models. The 1-layer model was limited to only wells that coincided with the glacial aquifer. In addition, 119 well construction report wells in the glacial sediments were removed as targets for the 1-layer model because their depth to water was greater than 70 feet, and early calibration attempts illustrated that these water levels seemed to be affected by vertical gradients in fine-grained material that could not be simulated with a 1-layer model. Thus, 217 water-level targets from wells in the USGS NWIS and 4,187 water-level targets from well-construction reports were used to calibrate the 1-layer model. For all models, well targets were assigned to a single model layer based on the well bottom elevation.

The weight assigned to individual water-level targets followed a similar confidence level approach as that used for the base-flow targets. Weights for water-level targets from wells in the USGS NWIS were computed as the inverse of the estimated measurement standard deviation as it relates to computing a multiyear mean target water level. That is, weights considered the number of measurements and an estimated cumulative error associated with the water-level 
$\boldsymbol{A}$

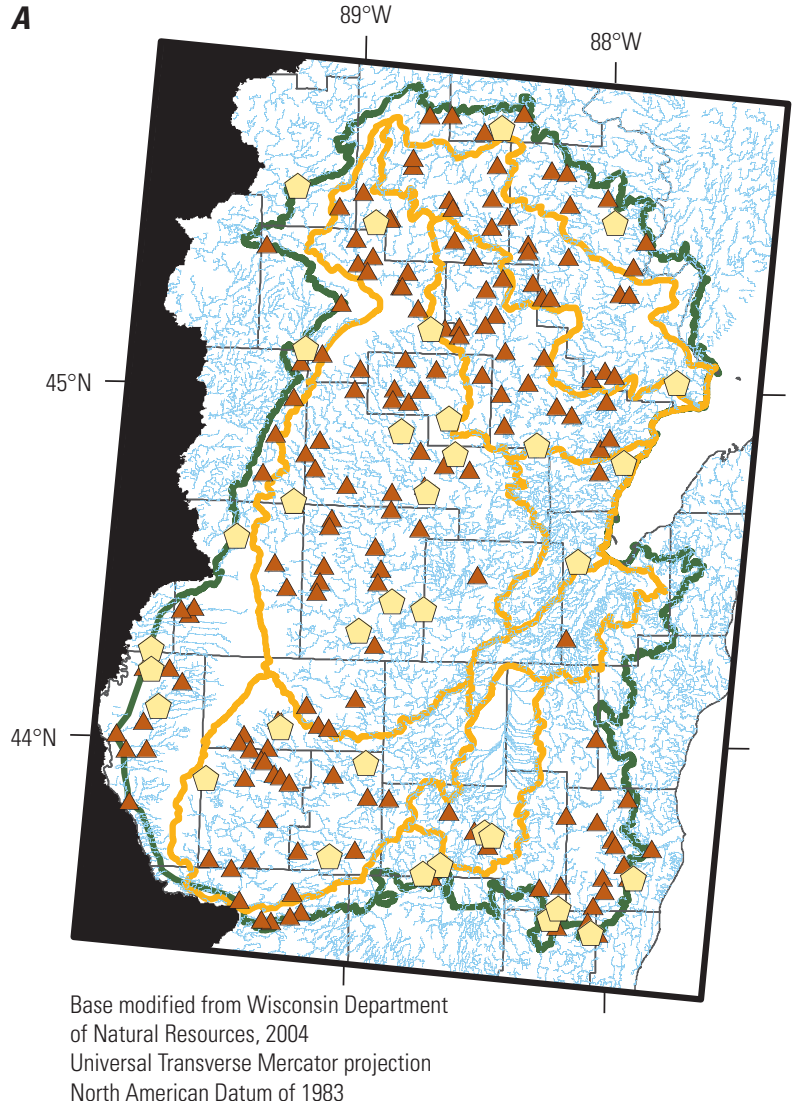

$B$

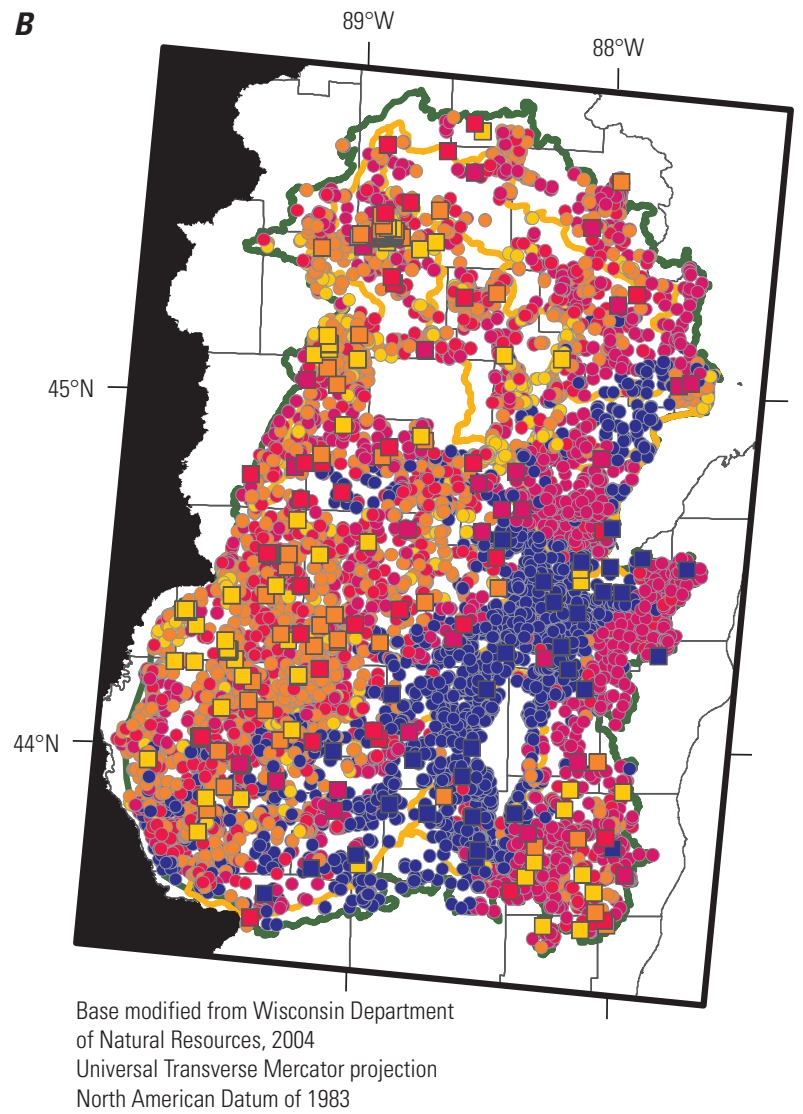

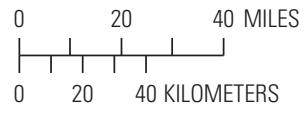

EXPLANATION

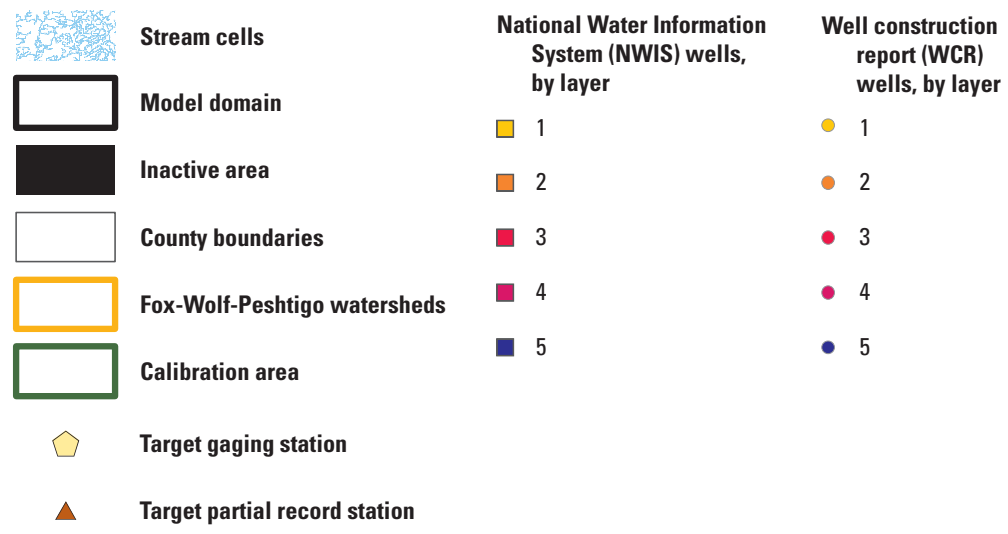

Figure 11. Targets used to calibrate the Fox-Wolf-Peshtigo models for $A$, stream base flow and $B$, water level. 
Table 6. National Water-Quality Assessment networks for which wells were used as water-level targets, regardless of the number of water-level measurements.

[NAWQA, National Water-Quality Assessment]

\begin{tabular}{|c|c|}
\hline NAWQA network name & Network description \\
\hline glacpas1 & $\begin{array}{l}\text { Principal aquifer survey of the glacial } \\
\text { aquifer. }\end{array}$ \\
\hline glacmss1 & $\begin{array}{l}\text { Model support study survey in the } \\
\text { glacial aquifer. }\end{array}$ \\
\hline glacetn 1 & $\begin{array}{l}\text { Enhanced trend network in the glacial } \\
\text { aquifer. }\end{array}$ \\
\hline wmiclusag1a & $\begin{array}{l}\text { Groundwater land-use study in } \\
\text { agricultural area, western Lake } \\
\text { Michigan drainage area } 1 .\end{array}$ \\
\hline wmiclusag2 & $\begin{array}{l}\text { Groundwater land-use study in } \\
\text { agricultural area, western Lake } \\
\text { Michigan drainage area } 2 .\end{array}$ \\
\hline wmicfpsag2a & $\begin{array}{l}\text { Flow-path study in agricultural area, } \\
\text { western Lake Michigan drainage } \\
\text { area } 2 .\end{array}$ \\
\hline $\begin{array}{l}\text { wmicsus2 (previously } \\
\text { called wmicmas } 2 \text { ) }\end{array}$ & $\begin{array}{l}\text { Groundwater study-unit survey (major } \\
\text { aquifer survey), western Lake } \\
\text { Michigan drainage. }\end{array}$ \\
\hline wmicreffol & $\begin{array}{l}\text { Reference monitoring wells in for- } \\
\text { ested areas, western Lake Michigan } \\
\text { drainage. }\end{array}$ \\
\hline
\end{tabular}

measurement method, accuracy, and source that provided the data, as described in Section 3 of the GWSI User's Manual (U.S. Geological Survey, 2016). The estimated errors used for this study to compute target weights from the water-level measurement codes in GWSI are listed in tables 7, 8, and 9, and the estimated errors associated with the number of water-level measurements are listed in table 10. Only non-NAWQA network wells in the USGS NWIS with cumulative measurementrelated errors from tables 7, 8 , and 9 of less than 1 foot were included as targets. The number of water-level measurements (table 10) was used as part of the weighting scheme because the mean of measured water level for a well with hundreds of measurements was expected to better represent the "true" multiyear mean water level than the mean water level for a well with only a few measurements. To facilitate estimating errors associated with the number of measurements, wells were categorized on a percentile basis. That is, the 10 percent of wells (90th percentile) with the most measurements were assigned the smallest error; the next 20 percent of wells with the next largest number of measurements (70th to 90th percentile) were assigned a slightly larger error, and so on. Weights for target wells from the USGS NWIS were then computed using a 95 percent confidence level as the inverse of the combined standard deviations for the composite measurement-related errors and errors associated with the number of measurements. Specifically, weights were computed as:

$$
w_{i}=\frac{1}{\sqrt{\left(c_{i} / 1.96\right)^{2}+\left(n_{i} / 1.96\right)^{2}}},
$$

where

$$
\begin{gathered}
w_{i} \quad \begin{array}{l}
\text { is the weight computed for an individual } \\
\text { target well from the USGS NWIS, }
\end{array} \\
c_{i} \quad \text { is the cumulative measurement-related error } \\
\text { from tables 7, 8, and 9; and } \\
n_{i} \quad \text { is the estimated error attributed to the number } \\
\text { of measurements for each well (table 10), } \\
\text { and 1.96 was obtained from a normal } \\
\text { probability table given a 95 percent } \\
\text { confidence interval (Davis, 1986). }
\end{gathered}
$$

Finally, weights for tightly clustered target wells from the USGS NWIS within the same or lower percentile category (table 10) were reduced by dividing the initial measurementerror weights from equation 1 by the number of such wells within a 10,000 -foot radius ( 10 model cells) so that the calibration was not unduly affected by sets of closely spaced wells from projects designed for other purposes.

Well construction report wells were categorized according to their "collection method code" attribute in the well construction report database, which was used to estimate the accuracy with which each well's location was determined. For example, wells located with a survey-grade global positioning system were expected to be more accurately located than wells with locations interpreted from a map. The subset of collection method codes from appendix B of Wisconsin Department of Natural Resources (2001) included in the FWP study area and the estimated vertical accuracies used for this report to weight each well construction report well are listed in table 11. In addition, each well construction report well had only one water-level measurement. Thus, a vertical error of 6 feet was assigned to each well construction report well and attributed to the ability of a single measurement to represent the "true" multiyear mean water level. This estimate was roughly based on multiyear water-level fluctuations observed in monitoring wells in Wisconsin, and the estimate ultimately proved to be adequate because the well construction report targets represented a reasonable part of the total weighted residuals for the calibration. Weights were computed for well construction report wells using the estimated vertical accuracies from table 11 and the estimated 6-foot vertical accuracy for a single measurement in a similar fashion as that used to compute weights for target wells from the USGS NWIS. 
Table 7. Estimated vertical error in water-level measurements based on the Groundwater Site Inventory method of measurement codes (U.S. Geological Survey, 2016, section 3.20) that were used to compute water-level target weights for wells in the National Water Information System.

\begin{tabular}{clc}
\hline $\begin{array}{c}\text { Water-level method of } \\
\text { measurement code }\end{array}$ & Meaning & $\begin{array}{c}\text { Estimated vertical } \\
\text { water-level error (foot) }\end{array}$ \\
\hline A & Airline measurement & 1.01 \\
B & Analog or graphic recorder & 0.01 \\
C & Calibrated airline measurement & 0.01 \\
E & Estimated & 5 \\
F & Transducer & 0.01 \\
G & Pressure-gage measurement & 0.01 \\
H & Calibrated pressure-gage measurement & 0.01 \\
L & Interpreted from geophysical logs & 0.1 \\
M & Manometer measurement & 0.01 \\
N & Nonrecording gage & 0.1 \\
R & Reported, method not known & 1.01 \\
S & Steel-tape measurement & 0.01 \\
T & Electric-tape measurement & 0.01 \\
U & Unknown & 0.1 \\
V & Calibrated electric tape-accuracy of instrument has been checked & 0.01 \\
Z & Other & 1.01 \\
\hline
\end{tabular}

Table 8. Estimated vertical error in water-level measurements based on the Groundwater Site Inventory water-level accuracy codes (U.S. Geological Survey, 2016, section 3.22) that were used to compute water-level target weights for wells in the National Water Information System.

\begin{tabular}{clc}
\hline $\begin{array}{c}\text { Water-level } \\
\text { accuracy code }\end{array}$ & \multicolumn{1}{c}{ Meaning } & $\begin{array}{c}\text { Estimated vertical } \\
\text { water-level error (foot) }\end{array}$ \\
\hline 0 & Water level accurate to nearest foot & 1.01 \\
1 & Water level accurate to nearest tenth of a foot & 0.1 \\
2 & Water level accurate to nearest one-hundredth of a foot & 0.01 \\
9 & Water level not accurate to nearest foot & 10 \\
\hline
\end{tabular}

\section{Calibration Parameters}

All three FWP models were calibrated in a similar way, in that the same set of parameters were estimated during the calibration step, tied to estimated parameters using a ratio, or fixed at initial values. The 5-layer models, however, had additional parameters representing the ratio of horizontal to vertical hydraulic conductivity, or vani, and parameters representing the bedrock aquifers, which were not needed to simulate the glacial aquifer with the 1-layer model. As described in the "Hydraulic Conductivity" section, vani was parameterized on a zonal-basis for each glacial category for all three models. For the 1-layer and 5-layer zoned hydraulic conductivity models, the minimum and maximum horizontal hydraulic conductivities for the glacial categories were tied at a 1 to 1 ratio to the expected hydraulic conductivity parameter so that the coarse fraction played no role in computing hydraulic conductivity. Details of how glacial categories, as originally described in tables 4 and 5 , were estimated or tied to other parameters for the 1-layer and 5-layer zoned models are listed in table 12. For the heterogeneous model, the minimum, expected, and maximum horizontal hydraulic conductivity values (min_hk, exp_hk, and max_hk, respectively) were either estimated directly or tied to other parameters, depending 
Table 9. Estimated vertical error in water-level measurements based on the Groundwater Site Inventory water-level source codes (U.S. Geological Survey, 2016, section 3.23) that were used to compute water-level target weights for wells in the National Water Information System.

\begin{tabular}{clc}
\hline $\begin{array}{c}\text { Water-level } \\
\text { source code }\end{array}$ & \multicolumn{1}{c}{ Meaning } & $\begin{array}{c}\text { Estimated vertical } \\
\text { water-level error (foot) }\end{array}$ \\
\hline A & Reported by another government agency & 0.01 \\
D & From driller's log or report & 5 \\
G & Private geologist consultant or university associate & 0.01 \\
L & $\begin{array}{l}\text { Depth interpreted from geophysical logs by personnel of } \\
\text { source agency }\end{array}$ & 0.1 \\
M & Memory (owner, operator, driller); less reliable than D & 10 \\
O & Reported by the owner of the well & 5 \\
R & Reported by person other than the owner, driller, or another & 0.1 \\
& government agency & 0.01 \\
S & Measured by personnel of reporting agency & 0.1 \\
\hline
\end{tabular}

Table 10. Estimated vertical error in target water level based on percentiles of the number of water-level measurements for individual wells, as used to compute water-level target weights for wells in the National Water Information System.

\begin{tabular}{lc}
\hline $\begin{array}{c}\text { Percentile of the number of } \\
\text { water-level measurements }\end{array}$ & $\begin{array}{c}\text { Estimated vertical } \\
\text { water-level error (foot) }\end{array}$ \\
\hline $\begin{array}{c}\text { More than the 90th percentile of } \\
\text { water-level measurements }\end{array}$ & 0.5 \\
$\begin{array}{l}\text { Between the 70th and 90th percentile } \\
\text { of water-level measurements }\end{array}$ & 1.0 \\
$\begin{array}{l}\text { Between the 35th and 70th percentile } \\
\text { of water-level measurements }\end{array}$ \\
$\begin{array}{l}\text { Fewer than the 35th percentile of } \\
\text { water-level measurements }\end{array}$ \\
\hline
\end{tabular}

on the sensitivity of the targets to individual parameters (table 13). For all three models, recharge was calibrated through two multiplier parameters that acted on initial cellby-cell recharge ( $\mathrm{RCH}$ and UZF1 packages) values from the SWB program. The two recharge multiplier parameters were mapped to the underlying glacial categories. That is, one recharge multiplier was used to adjust recharge values within generally coarse glacial categories (sandy till and coarse-stratified sediment), whereas a second multiplier was used to adjust recharge within the remaining glacial categories. The highest 1 percent of recharge values in the models was limited to the 99th percentile recharge value (approximately $21 \mathrm{in} / \mathrm{yr}$ ) to account for problems with routing of water from adjacent cells that can occasionally cause locally overestimated recharge (Bradbury and others, in press). A single multiplier also was used to adjust the vertical hydraulic conductivity used to compute streambed conductance for SFR2 cells. Finally, for the 5-layer models, multiplier parameters were used to adjust the horizontal and vertical hydraulic conductivity values in the bedrock layers. Bedrock hydraulic conductivity values were originally smoothed from the "intermediate" LMB model by Feinstein and others (2016). The multiplier parameters used to calibrate recharge, vertical conductivity for SFR2 cells, and bedrock hydraulic conductivity are listed in table 14 . 
Table 11. Estimated vertical error in water-level measurements based on horizontal well location accuracy as estimated from collection method codes in appendix B from Wisconsin Department of Natural Resources (2001). The estimated vertical errors were used to compute weights for water-level targets from well-construction reports.

[GPS, global positioning system; USGS, U.S. Geological Survey]

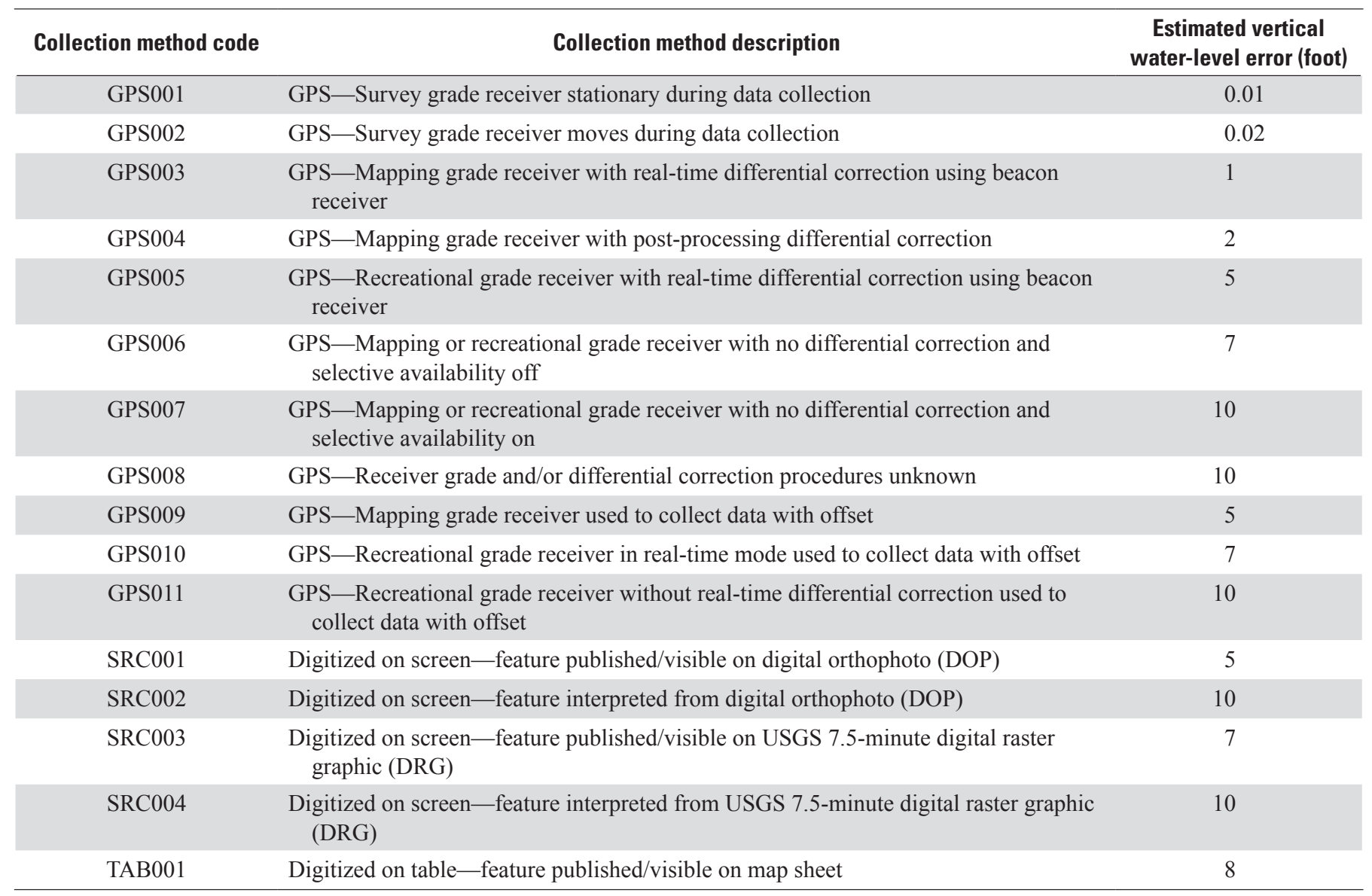


Table 12. Parameters used to calibrate hydraulic conductivity of the glacial sediments in the 1-layer and 5-layer zoned Fox-Wolf-Peshtigo MODFLOW models.

[Min_hk, minimum horizontal hydraulic conductivity; Exp_hk, expected horizontal hydraulic conductivity; Max_hk, maximum horizontal hydraulic conductivity; vani, vertical anisotropy computed as the ratio of horizontal to vertical hydraulic conductivity; *, vani was only estimated for the 5-layer models; $\times$, times; $1: 1$, one to one ratio]

\begin{tabular}{cclcccc}
\hline Layers & $\begin{array}{c}\text { Glacial } \\
\text { category }\end{array}$ & Category description & Min_hk & Exp_hk & Max_hk & vani* \\
\hline $1-3$ & 1 & Clayey till & $1 \times$ Exp_hk & estimated & $1 \times$ Exp_hk & $2 \times$ loamy till \\
$1-3$ & 2 & Loamy till & $1 \times$ Exp_hk & estimated & $1 \times$ Exp_hk & estimated \\
$1-3$ & 3 & Sandy till & $1 \times$ Exp_hk & estimated & $1 \times$ Exp_hk & estimated \\
$1-3$ & 4 & Fine stratified & $1 \times$ Exp_hk & estimated & $1 \times$ Exp_hk & estimated \\
$1-3$ & 5 & Medium stratified & Tied $1: 1$ to parameters for loamy till \\
$1-3$ & 6 & Coarse stratified & $1 \times$ Exp_hk $\quad$ estimated $1 \times$ Exp_hk estimated \\
$1-3$ & 7 & Organic & \multicolumn{2}{c}{ Tied $1: 1$ to parameters for loamy till } \\
$1-3$ & 8 & Undifferentiated & Not estimated-located in inactive cells only \\
\hline
\end{tabular}

Table 13. Parameters used to calibrate hydraulic conductivity of the glacial sediments in the 5-layer heterogeneous Fox-Wolf-Peshtigo MODFLOW model.

[Min_hk, minimum horizontal hydraulic conductivity; Exp_hk, expected horizontal hydraulic conductivity; Max_hk, maximum horizontal hydraulic conductivity; vani, vertical anisotropy computed as the ratio of horizontal to vertical hydraulic conductivity; $1 / 5,1$ divided by $5 ; \times$, times; $1: 1$, one to one ratio]

\begin{tabular}{|c|c|c|c|c|c|c|}
\hline Layers & $\begin{array}{c}\text { Glacial } \\
\text { category }\end{array}$ & $\begin{array}{c}\text { Category } \\
\text { description }\end{array}$ & Min_hk & Exp_hk & Max_hk & vani \\
\hline $1-3$ & 1 & Clayey till & 1/5 × Exp_hk & estimated & $5 \times$ Exp_hk & $2 \times$ loamy till \\
\hline $1-3$ & 2 & Loamy till & $1 / 5 \times$ Exp_hk & estimated & $10 \times$ Exp_hk & estimated \\
\hline $1-3$ & 3 & Sandy till & estimated & estimated & estimated & estimated \\
\hline $1-3$ & 4 & Fine stratified & estimated & estimated & estimated & estimated \\
\hline $1-3$ & 5 & Medium stratified & \multicolumn{4}{|c|}{ Tied $1: 1$ to parameters for loamy till } \\
\hline $1-3$ & 6 & Coarse stratified & estimated & estimated & estimated & estimated \\
\hline $1-3$ & 7 & Organic & \multicolumn{4}{|c|}{ Tied $1: 1$ to parameters for loamy till } \\
\hline $1-3$ & 8 & Undifferentiated & \multicolumn{4}{|c|}{ Not estimated-located in inactive cells only } \\
\hline
\end{tabular}

Table 14. Multiplier parameters used to calibrate streambed conductance, recharge, and hydraulic conductivity of the bedrock aquifers in the Fox-Wolf-Peshtigo MODFLOW models. All multipliers were initially set to a value of 1.0.

[*Hydraulic conductivity multipliers for layers 4 and 5 were estimated only for the 5 -layer models.]

\begin{tabular}{ll}
\hline \multicolumn{1}{c}{ Parameter } & \multicolumn{1}{c}{ Parameter description } \\
\hline SFR2 vK_mult & Multiplier on cell-by-cell vertical hydraulic conductivity (vK) used to compute SFR2 conductance. \\
\hline RCH_mult_coarse & $\begin{array}{c}\text { Multiplier on recharge from SWB for areas underlain by generally coarse-grained glacial categories (sandy till } \\
\text { and coarse-stratified deposits). }\end{array}$ \\
RCH_mult_non-coarse & $\begin{array}{c}\text { Multiplier on recharge from SWB for areas underlain by noncoarse-grained glacial categories (clayey and } \\
\text { loamy till, fine and medium stratified, organic). }\end{array}$ \\
L4_hK_mult* & Multiplier on horizontal hydraulic conductivity for unconfined bedrock in layer 4. \\
L4_vK_mult* & Multiplier on vertical hydraulic conductivity for unconfined bedrock in layer 4. \\
L5_hK_mult* & Multiplier on horizontal hydraulic conductivity for confined bedrock in layer 5. \\
L5_vK_mult* & Multiplier on vertical hydraulic conductivity for confined bedrock in layer 5. \\
\hline
\end{tabular}




\section{Calibration Results}

The steady-state models were designed to simulate conditions that approximated 1971-2012 because that was the period represented by most base-flow and water-level targets, and withdrawal wells. Although steady-state models simulate long-term mean conditions, measured water levels and base flows that are used for calibration fluctuate and, therefore, to compute the long-term means is not always straight forward (see the "Calibration Targets" section). An approximate evaluation of data quality was included in the calibration via the weight assigned to each target in PEST, and weighted residuals between measured and simulated values were used by PEST to determine the model best fit. Nonetheless, because of these temporal inconsistencies and simplifications inherent to constructing a model, perfect agreement between the simulated and measured values was not expected.

Comparison of spatial distributions of water-level (fig. 12) and base-flow (fig. 13) residuals (difference between target and simulated values) illustrates similarities and differences among the models. For example, all three models exhibit water-level mounding along the divide between the Wisconsin River watershed to the west and the Fox and Wolf River watersheds to the east in the southwestern part of the model domain (fig. 12). These similarities are likely associated with similarities in the conceptual model and the model construction, such as how hydraulic conductivity and recharge were associated with glacial categories during calibration. Conversely, the most notable difference among the models is the higher density of water-level targets within the lower Fox River watershed in the 5-layer models because of inclusion of bedrock target wells (fig. 12). Base flows tended to be somewhat undersimulated in the northwest and southern parts of the study area and somewhat oversimulated in the central area for all three models, yet generally balanced in terms of total oversimulation and undersimulation of targets.

Estimated parameter values were generally similar among the models, except that the minimum and maximum hydraulic conductivity values for the heterogeneous model increased the range of simulated hydraulic conductivities in the heterogeneous model compared with the zoned models. The calibrated parameter values for the 1-layer, 5-layer zoned, and 5-layer heterogeneous models are listed in tables 15, 16, and 17, respectively. A single horizontal hydraulic conductivity (hK_) value for each glacial category is listed for the 1- and 5-layer zoned models in tables 15 and 16; the minimum, expected, and maximum hydraulic conductivities are listed for the heterogeneous model in table 17. All parameter names are described within these tables. Spatial distributions of the calibrated hydraulic conductivity and recharge for the 5-layer heterogeneous model are shown in figures 14,15, 16, 17, and 18 .

The range in localized cell-by-cell recharge values (fig. 18) was predictably greater than the range for the spatially larger watershed-scale recharge values computed by Gebert and others (2011). To address spurious infiltration rates estimated by the SWB model, recharge was capped at the 99th percentile of values to remove the highest 1 percent of values because they were expected to be associated with closed depressions where down-slope routed runoff could cause the SWB program to over-estimate deep infiltration. Nonetheless, application of local recharge values from this regional model to separate local models or for other purposes should be performed with caution and evaluation. Given the regional focus of the FWP model, the spatial recharge patterns were generally well-matched with the distribution of watershed-averaged recharge rates computed by Gebert and others (2011). Long-term (1970-99) watershed-average recharge rates by Gebert and others (2011) for the Fox-Wolf River basin range from less than $1 \mathrm{in} / \mathrm{yr}$ in many eastern watersheds underlain by fine-grained glacial deposits to more than $14 \mathrm{in} / \mathrm{yr}$ in some western watersheds underlain by coarsegrained deposits. The average calibrated recharge for the FWP model domain was about $6.5 \mathrm{in} / \mathrm{yr}$, but ranged from an average of about $3.8 \mathrm{in} / \mathrm{yr}$ in the clayey and fine-grained glacial categories (fig. 7) to about $10.3 \mathrm{in} / \mathrm{yr}$ in the sandy and coarse-grained glacial categories; average recharge for the loamy, mediumgrained, and organic glacial categories was about $4.3 \mathrm{in} / \mathrm{yr}$. 
A

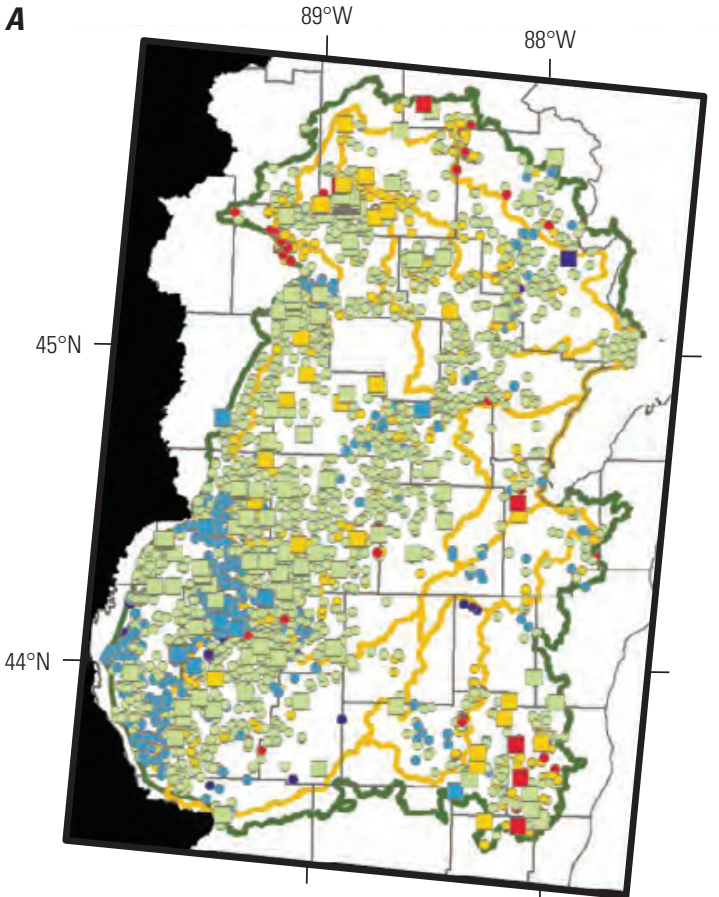

Base modified from Wisconsin Department of Natural Resources, 2004

Universal Transverse Mercator projection North American Datum of 1983

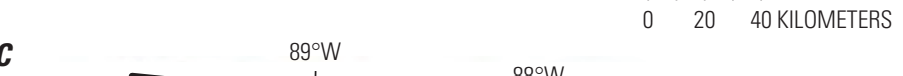

C

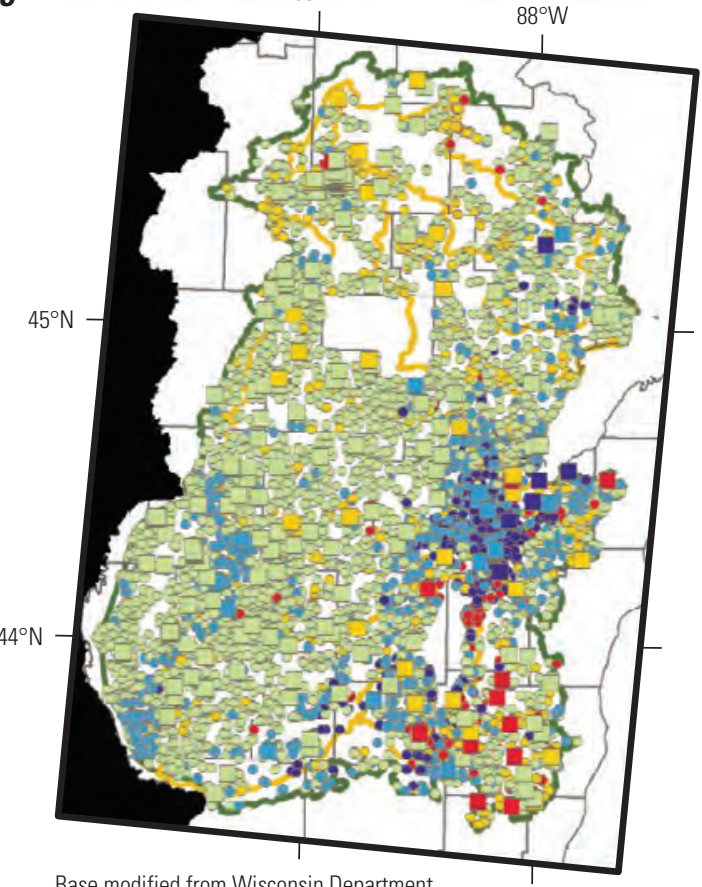

Base modified from Wisconsin Department of Natural Resources, 2004

Universal Transverse Mercator projection

North American Datum of 1983
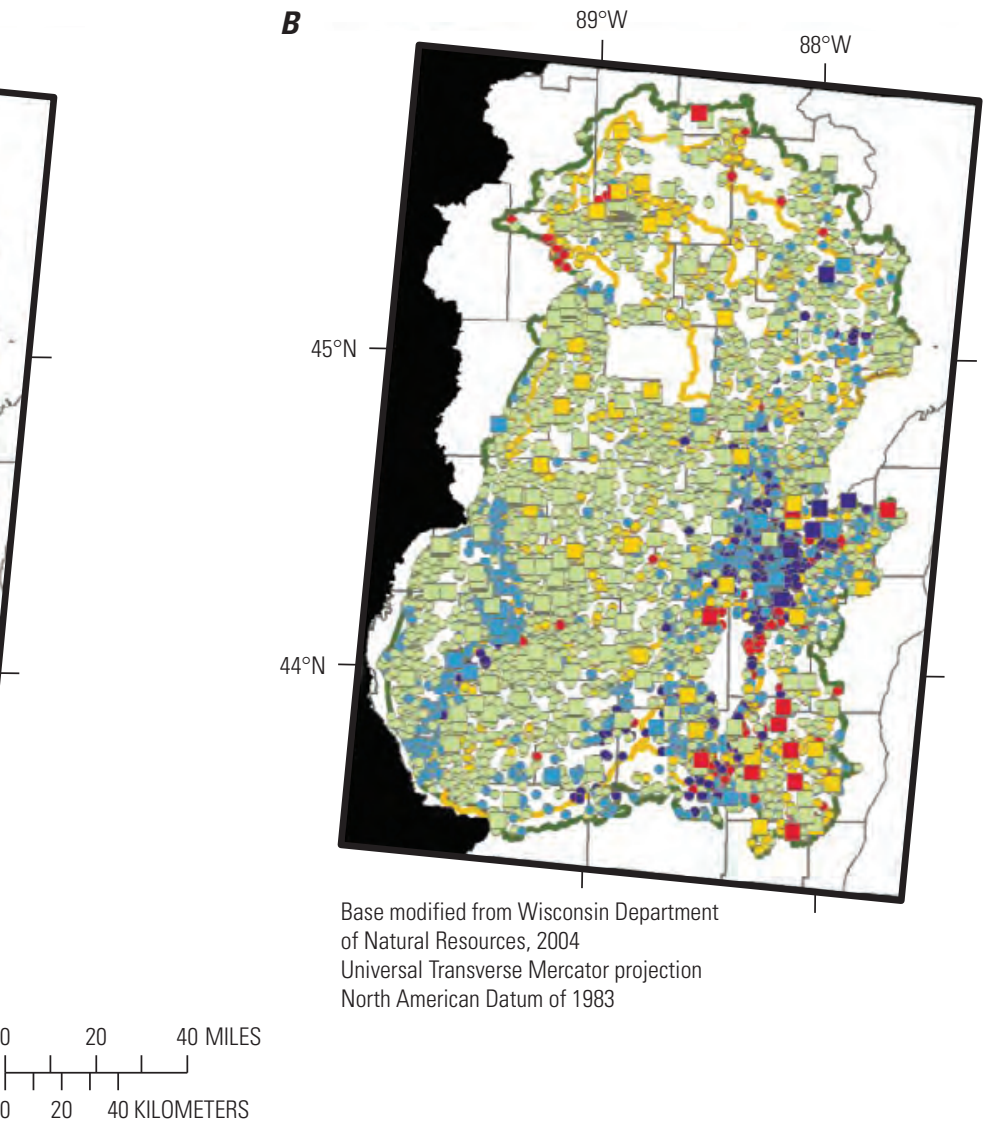

North American Datum of 1983

\section{EXPLANATION}

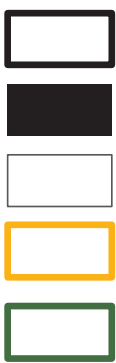

Model domain

Inactive area

County boundaries

Fox-Wolf-Peshtigo watersheds

Calibration area
Well construction report (WCR) residuals

- Greater than 50 feet too high

- 15 to 50 feet too high

Within 15 feet of target value

15 to 50 feet too low

- Greater than 50 feet too low

National Water Information System (NWIS) residuals

Greater than 50 feet too high

15 to 50 feet too high

Within 15 feet of target value

$\square \quad 15$ to 50 feet too low

Greater than 50 feet too low

Figure 12. Water-level residuals for the $A, 1$-layer model; $B$, 5-layer zoned model; and $C$, 5 -layer heterogeneous model. 
$\boldsymbol{A}$

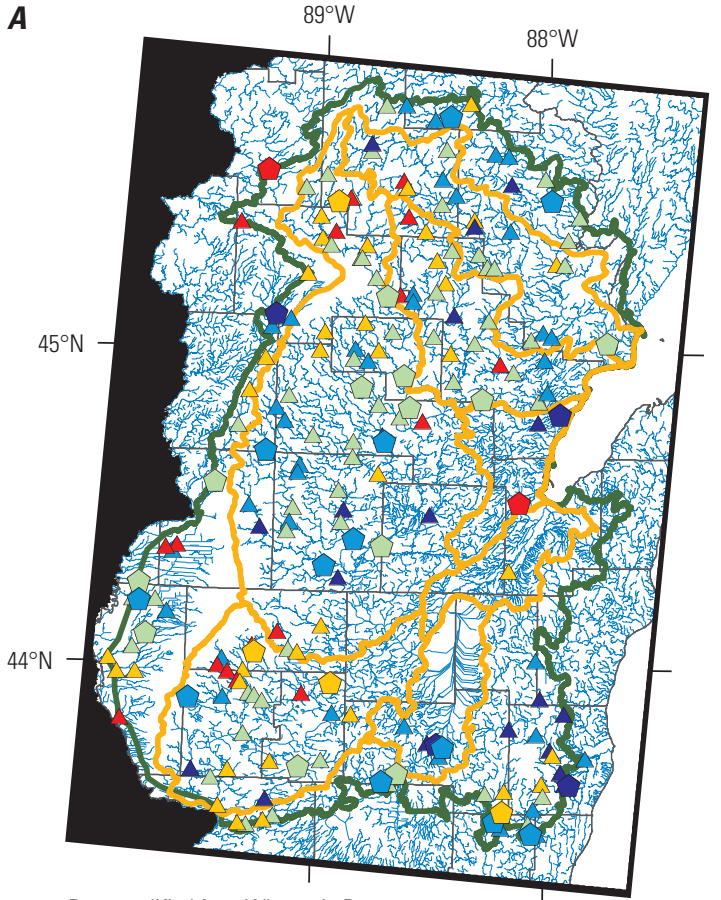

Base modified from Wisconsin Department of Natural Resources, 2004

Universal Transverse Mercator projection North American Datum of 1983

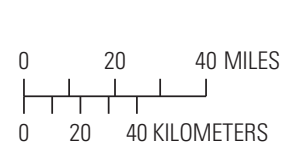

$c$

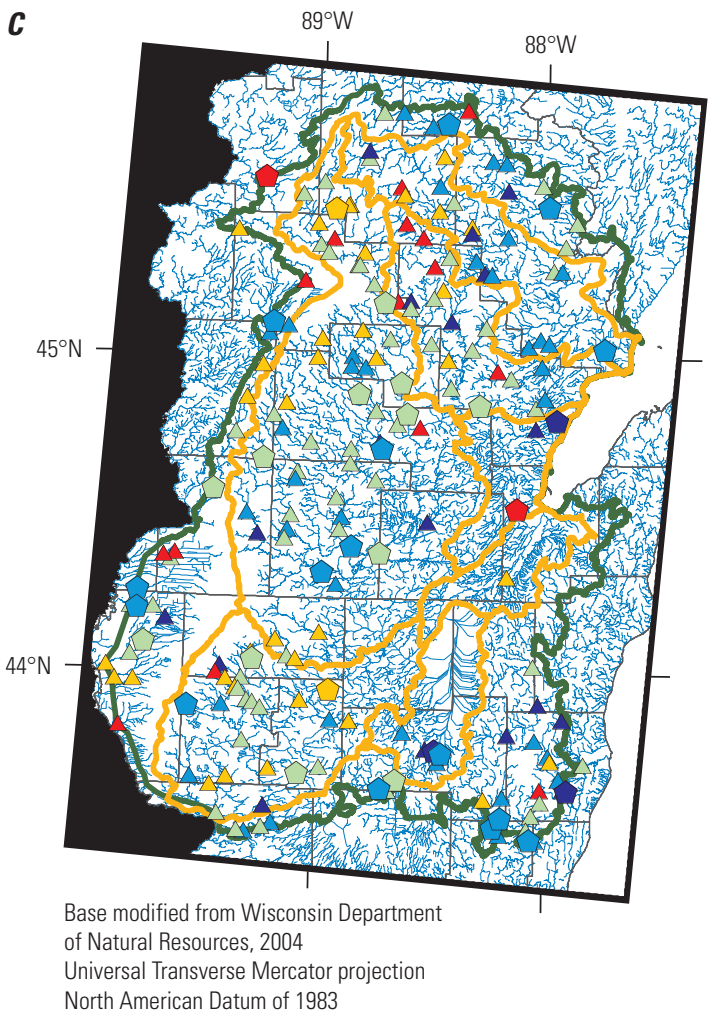

B

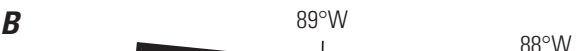

$45^{\circ} \mathrm{N}$

$44^{\circ} \mathrm{N}$

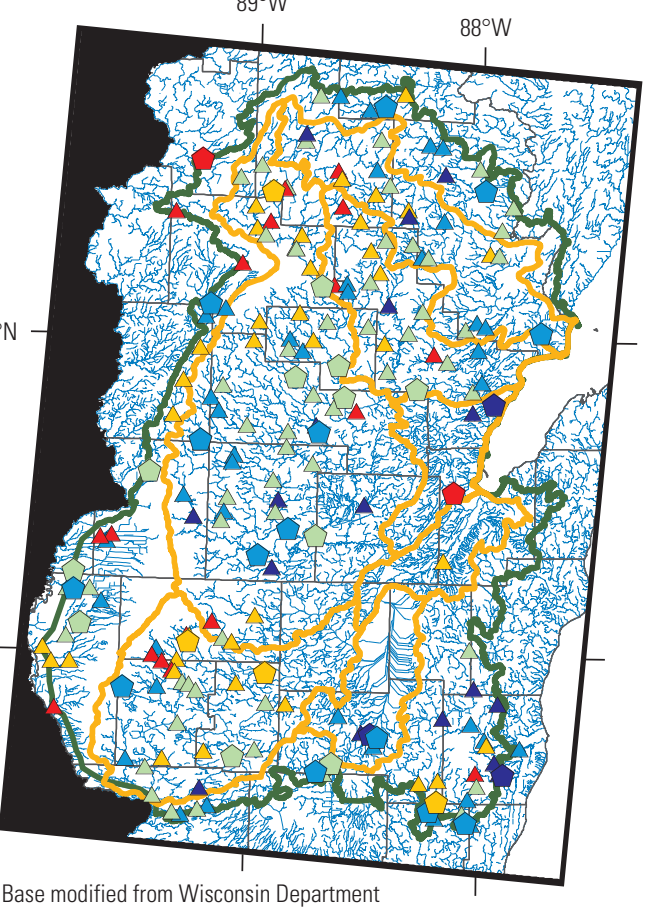

Base modiffied from Wisconsin Department of Natural Resources, 2004

Universal Transverse Mercator projection North American Datum of 1983

\section{EXPLANATION}

\begin{tabular}{|l|l}
\hline & Model domain \\
\hline & Inactive area \\
\hline & Fox-Wolf-Peshtigo watersheds \\
\hline & Calibration area \\
\hline & County boundaries \\
\hline & Stream \\
\hline Gaging station residuals \\
$\quad$ Greater than 50 percent too high \\
\hline$\quad$ 15 to 50 percent too high \\
$\quad$ Within 15 percent of target value \\
\hline$\quad 15$ to 50 percent too low \\
$\quad$ Greater than 50 percent too low \\
Lowflow station residuals \\
$\Delta \quad$ Greater than 50 percent too high \\
$\Delta \quad 15$ to 50 percent too high \\
$\triangle \quad$ Within 15 percent of target value \\
$\triangle \quad 15$ to 50 percent too low \\
$\Delta \quad$ Greater than 50 percent too low
\end{tabular}

Figure 13. Base-flow residuals for the $A, 1$-layer model; $B, 5$-layer zoned model; and $C$, 5-layer heterogeneous model. 
Table 15. Calibrated hydraulic conductivity of the glacial sediments for the 1-layer model.

[ft/d, foot per day]

\begin{tabular}{llc}
\hline \multicolumn{1}{c}{ Parameter name } & \multicolumn{1}{c}{ Parameter description } & Parameter value \\
\hline hK_1 & Hydraulic conductivity of clayey till (category 1) & $7.2 \mathrm{ft} / \mathrm{d}$ \\
$\mathrm{hK} \_2$ & Hydraulic conductivity of loamy till (category 2) & $2.7 \mathrm{ft} / \mathrm{d}$ \\
\hline $\mathrm{hK} \_3$ & Hydraulic conductivity of sandy till (category 3) & $118 \mathrm{ft} / \mathrm{d}$ \\
$\mathrm{hK} \_4$ & Hydraulic conductivity of fine stratified (category 4) & $7.6 \mathrm{ft} / \mathrm{d}$ \\
hK_5 & Hydraulic conductivity of medium stratified (category 5) & $2.7 \mathrm{ft} / \mathrm{d}$ \\
hK_6 & Hydraulic conductivity of coarse stratified (category 6) & $93 \mathrm{ft} / \mathrm{d}$ \\
hK_7 & Hydraulic conductivity of organic (category 7) & $2.7 \mathrm{ft} / \mathrm{d}$ \\
\hline SFR2_vK_mult & Multiplier on cell-by-cell vertical hydraulic conductivity for SFR2 cells & 0.99 \\
RCH_mult_coarse & Multiplier for recharge underlain by coarse categories (sandy till and coarse stratified) & 1.39 \\
RCH_mult_non-coarse & Multiplier for recharge underlain by noncoarse categories & 0.55 \\
\hline
\end{tabular}

Table 16. Calibrated hydraulic conductivity of the glacial sediments for the 5-layer zoned model.

[ft/d, foot per day]

\begin{tabular}{llc}
\hline \multicolumn{1}{c}{ Parameter name } & \multicolumn{1}{c}{ Parameter description } & Parameter value \\
\hline hK_1 & Hydraulic conductivity of clayey till (category 1) & $4.7 \mathrm{ft} / \mathrm{d}$ \\
\hline hK_2 & Hydraulic conductivity of loamy till (category 2) & $5.7 \mathrm{ft} / \mathrm{d}$ \\
\hline hK_3 & Hydraulic conductivity of sandy till (category 3) & $117 \mathrm{ft} / \mathrm{d}$ \\
\hline hK_4 & Hydraulic conductivity of fine stratified (category 4) & $11 \mathrm{ft} / \mathrm{d}$ \\
\hline hK_5 & Hydraulic conductivity of medium stratified (category 5) & $5.7 \mathrm{ft} / \mathrm{d}$ \\
\hline hK_6 & Hydraulic conductivity of coarse stratified (category 6) & $96 \mathrm{ft} / \mathrm{d}$ \\
\hline hK_7 & Hydraulic conductivity of organic (category 7) & $5.7 \mathrm{ft} / \mathrm{d}$ \\
\hline vani_1 & Horizontal to vertical anisotropy of clayey till & 8.7 \\
\hline vain_2 & Horizontal to vertical anisotropy of loamy till & 4.3 \\
\hline vani_3 & Horizontal to vertical anisotropy of sandy till & 1.0 \\
\hline vani_4 & Horizontal to vertical anisotropy of fine-stratified deposits & 1.6 \\
\hline vain_5 & Horizontal to vertical anisotropy of medium-stratified deposits & 4.3 \\
\hline vani_6 & Horizontal to vertical anisotropy of coarse-stratified deposits & 7.6 \\
\hline vani_7 & Horizontal to vertical anisotropy of organic material & 4.3 \\
\hline SFR2_vK_mult & Multiplier on cell-by-cell vertical hydraulic conductivity for SFR2 cells & 1.00 \\
\hline RCH_mult_coarse & Multiplier for recharge underlain by coarse categories (sandy till and coarse stratified) & 1.38 \\
\hline RCH_mult_non-coarse & Multiplier for recharge underlain by noncoarse categories & 0.56 \\
\hline L4_hK_mult & Multiplier for horizontal hydraulic conductivity in layer 4 & 0.53 \\
\hline L4_vK_mult & Multiplier for vertical hydraulic conductivity in layer 4 & 4.3 \\
\hline L5_hK_mult & Multiplier for horizontal hydraulic conductivity in layer 5 & 0.53 \\
\hline L5_vK_mult & Multiplier for vertical hydraulic conductivity in layer 5 & 1.3 \\
\hline
\end{tabular}


Table 17. Calibrated hydraulic conductivity of the glacial sediments for the 5-layer heterogeneous model.

[hK, hydraulic conductivity; ft/d, foot per day; min, minimum; exp, expected; max, maximum]

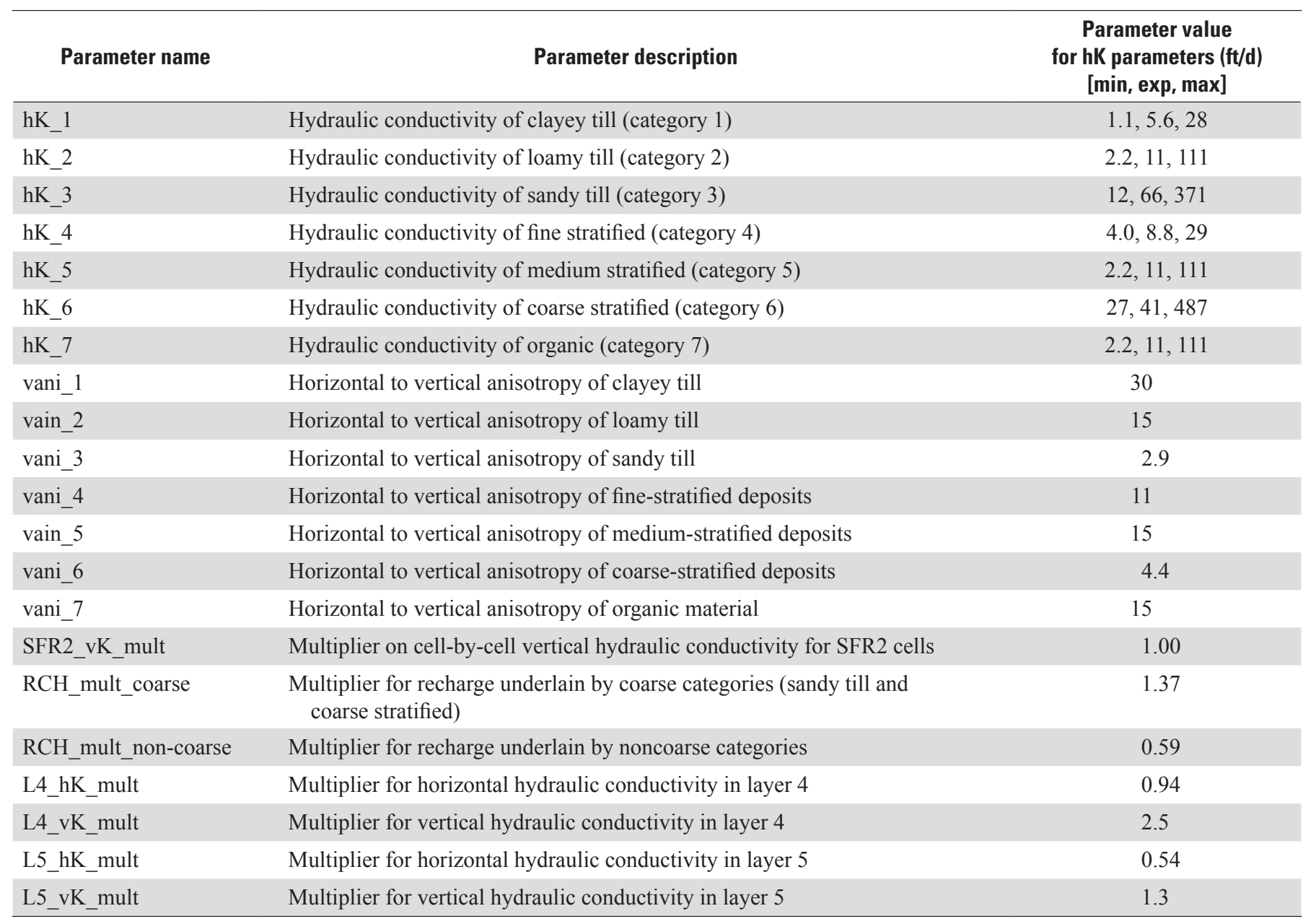


$\boldsymbol{A}$

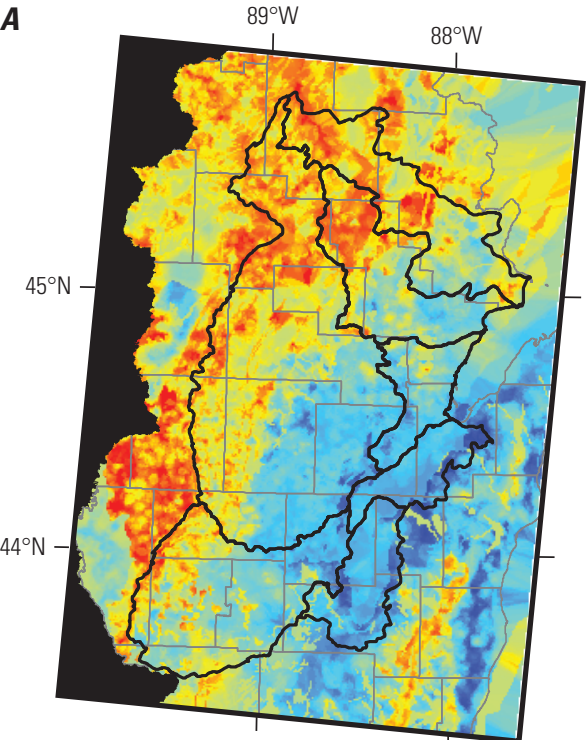

Base modified from Wisconsin Department of Natural Resources, 2004

Universal Transverse Mercator projection

North American Datum of 1983
$\boldsymbol{B}$

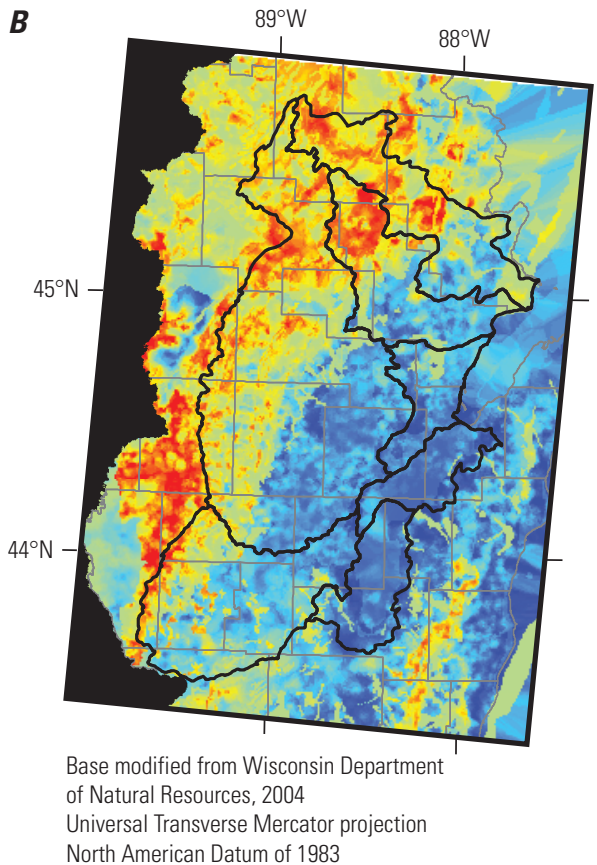

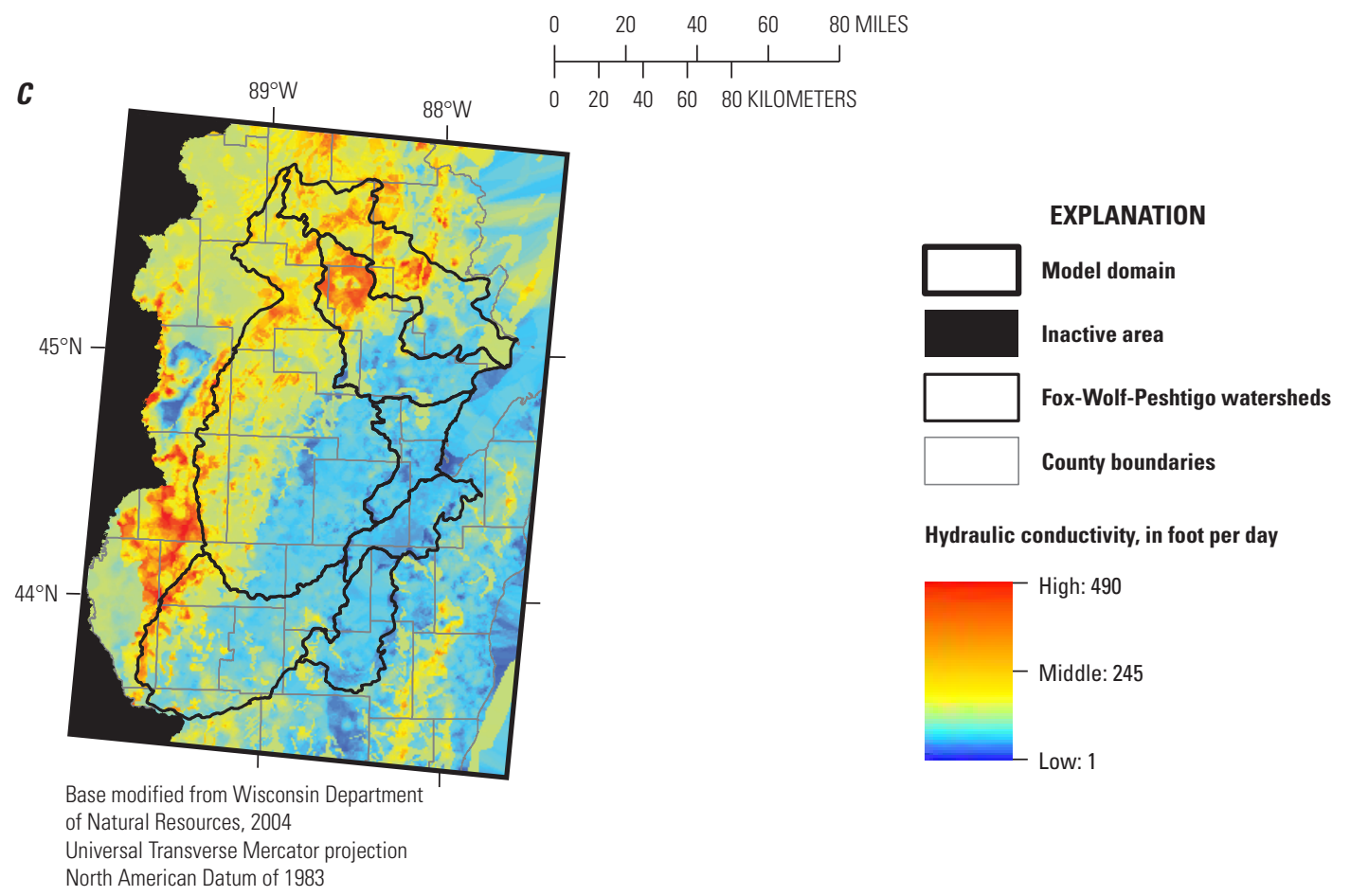

Figure 14. Calibrated horizontal hydraulic conductivity for glacial deposits of the 5-layer heterogeneous model in $A$, layer $1 ; B$, layer 2; and $C$, layer 3 . 
$\boldsymbol{A}$

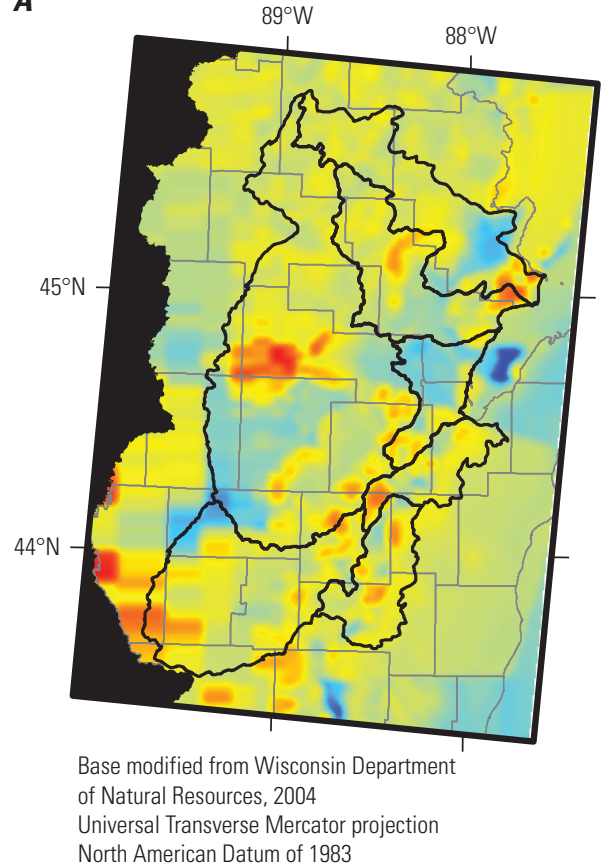

$\boldsymbol{B}$

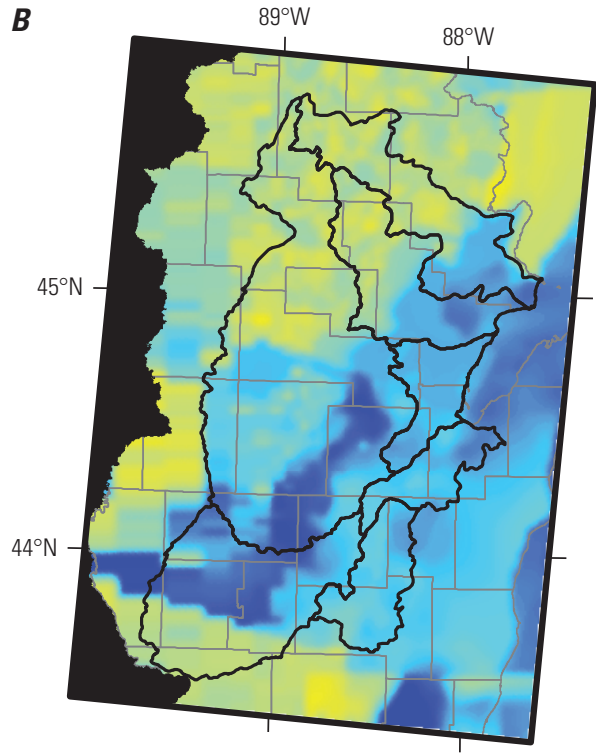

Base modified from Wisconsin Department of Natural Resources, 2004

Universal Transverse Mercator projection

North American Datum of 1983

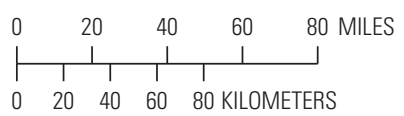

EXPLANATION

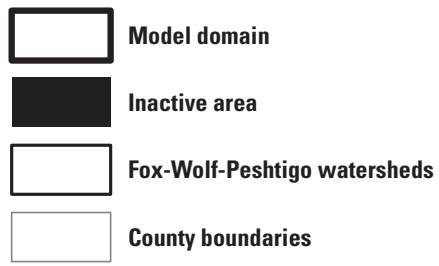

Hydraulic conductivity, in foot per day

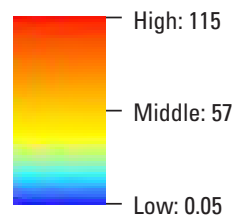

Figure 15. Calibrated horizontal hydraulic conductivity of the 5-layer heterogeneous model, as modified from the "intermediate" model of Feinstein and others (2016), in $A$, unconfined bedrock in layer 4 and $B$, confined bedrock in layer 5 . 
$\boldsymbol{A}$

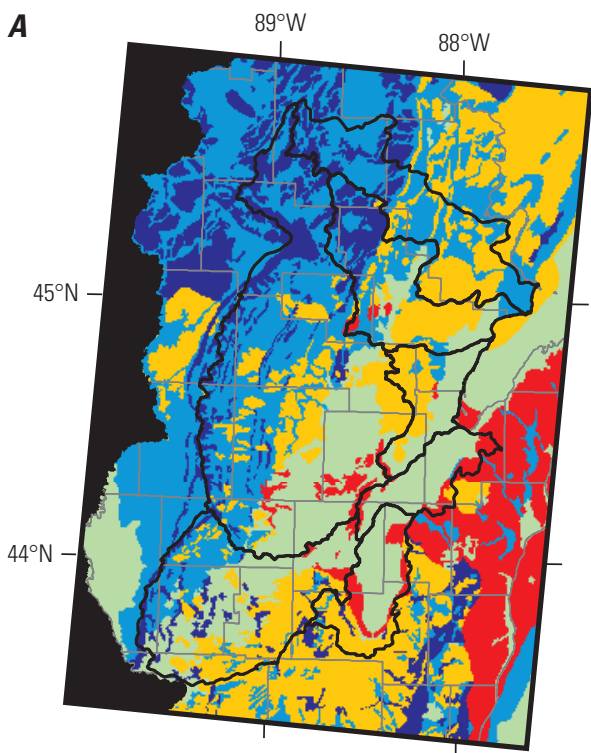

Base modified from Wisconsin Department of Natural Resources, 2004

Universal Transverse Mercator projection North American Datum of 1983

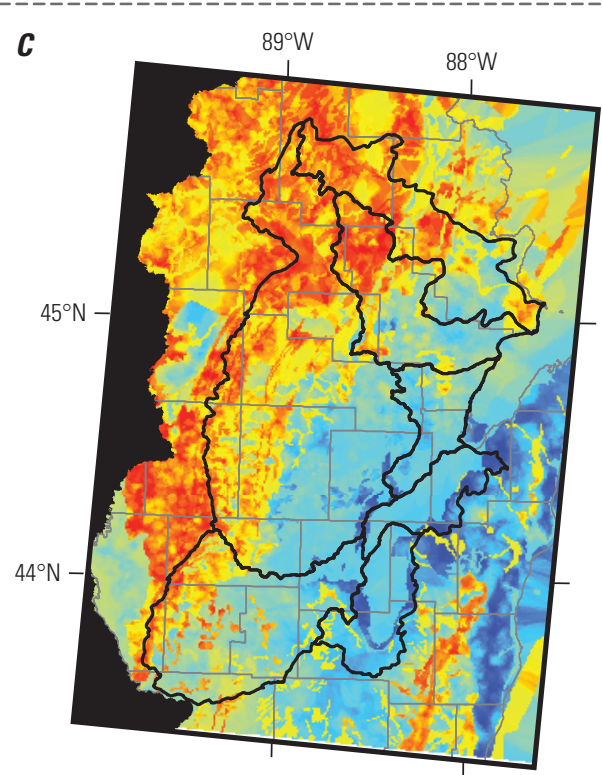

Base modified from Wisconsin Department of Natural Resources, 2004

Universal Transverse Mercator projection North American Datum of 1983

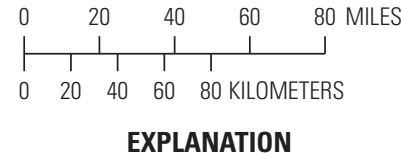

Horizontal to vertical conductivity ratio (vani) (fig. 16A)

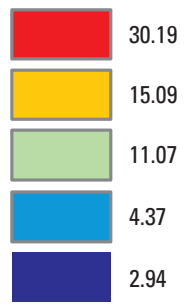

B

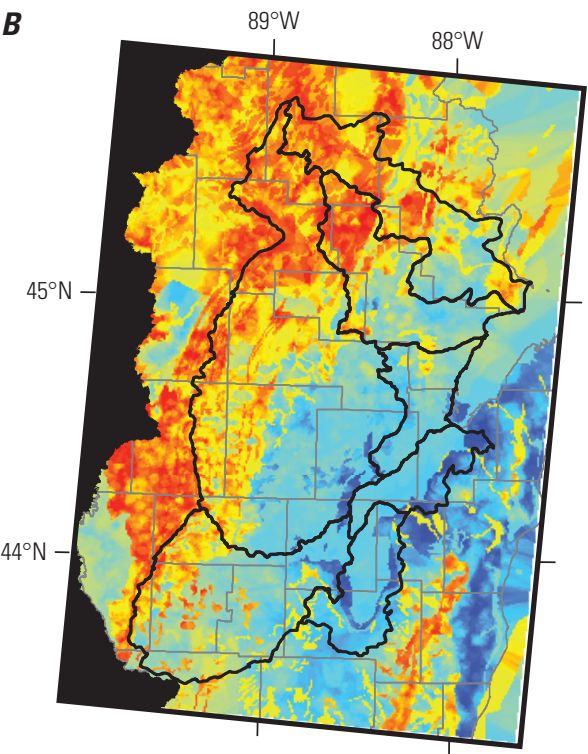

Base modified from Wisconsin Department of Natural Resources, 2004

Universal Transverse Mercator projection North American Datum of 1983

D

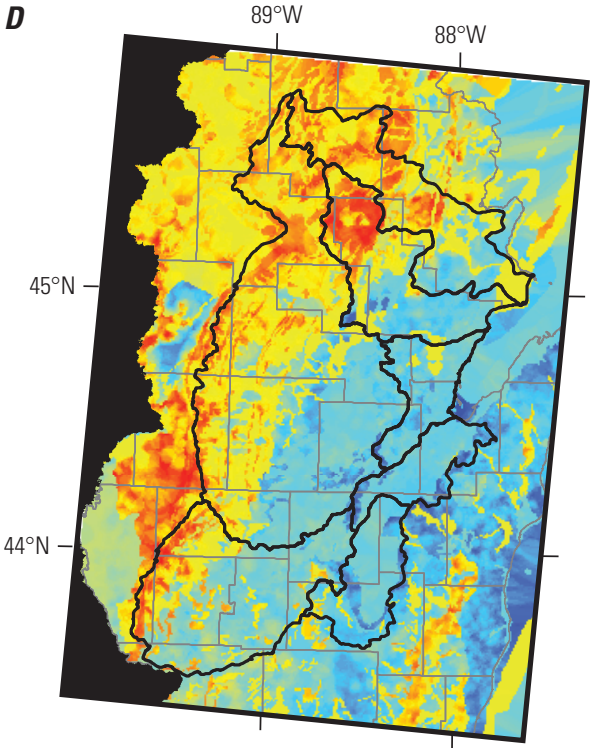

Base modified from Wisconsin Department of Natural Resources, 2004

Universal Transverse Mercator projection North American Datum of 1983
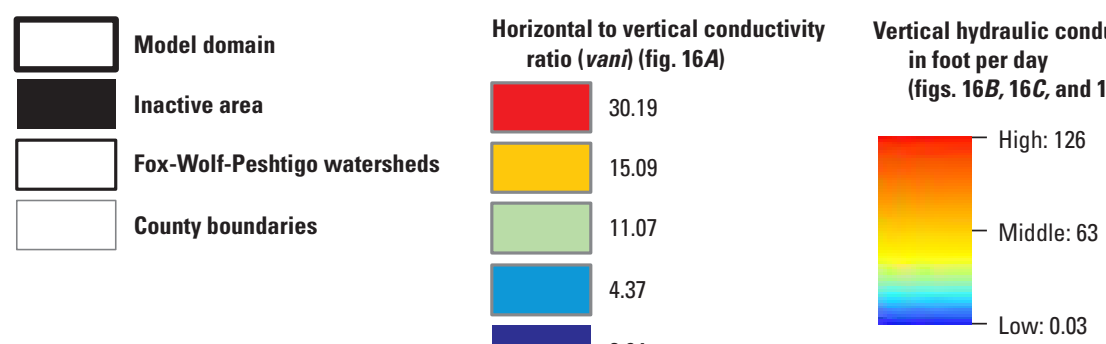

Figure 16. The 5 -layer heterogeneous model of $A$, calibrated horizontal to vertical anisotropy for glacial deposits; $B$, vertical hydraulic conductivity in layer $1 ; C$, vertical hydraulic conductivity in layer 2 ; and $D$, vertical hydraulic conductivity in layer 3 . 
$\boldsymbol{A}$

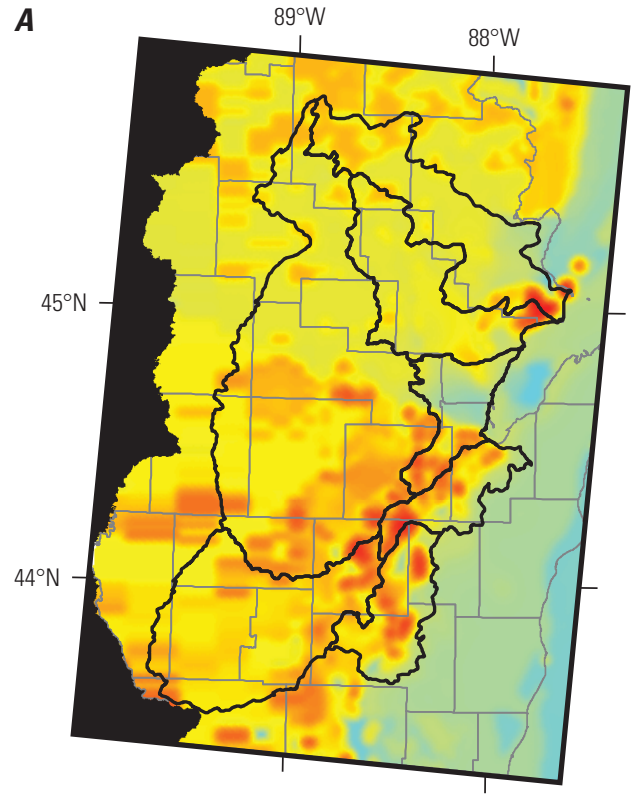

Base modified from Wisconsin Department of Natural Resources, 2004

Universal Transverse Mercator projection North American Datum of 1983

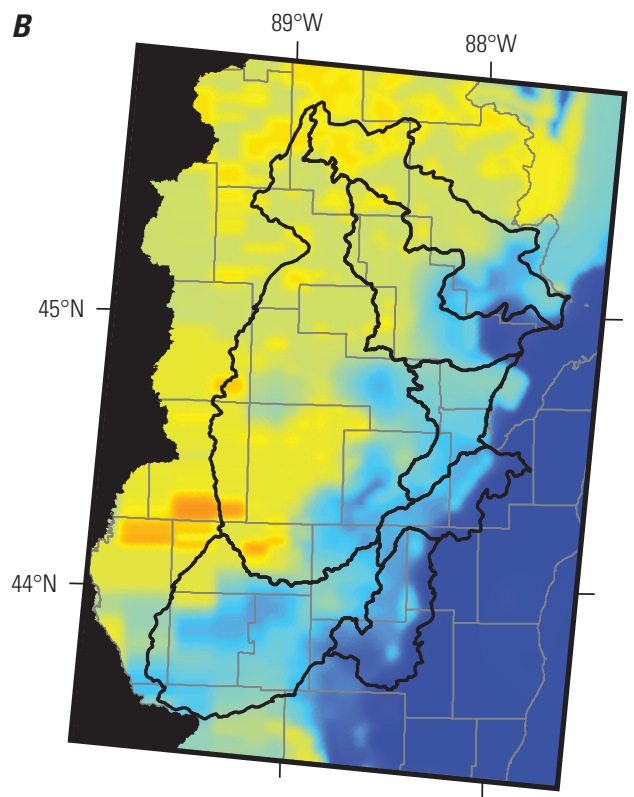

Base modified from Wisconsin Department of Natural Resources, 2004

Universal Transverse Mercator projection North American Datum of 1983

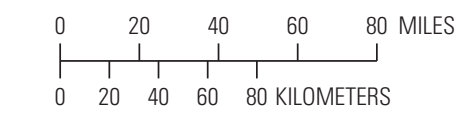

EXPLANATION

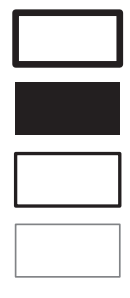

Model domain

Inactive area

Vertical hydraulic conductivity,

in foot per day

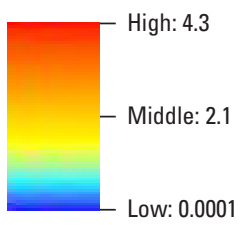

Figure 17. Calibrated vertical hydraulic conductivity of the 5-layer heterogeneous model, as modified from the “intermediate" model of Feinstein and others (2016), in $A$, unconfined bedrock in layer 4 and $B$, confined bedrock in layer 5 . 


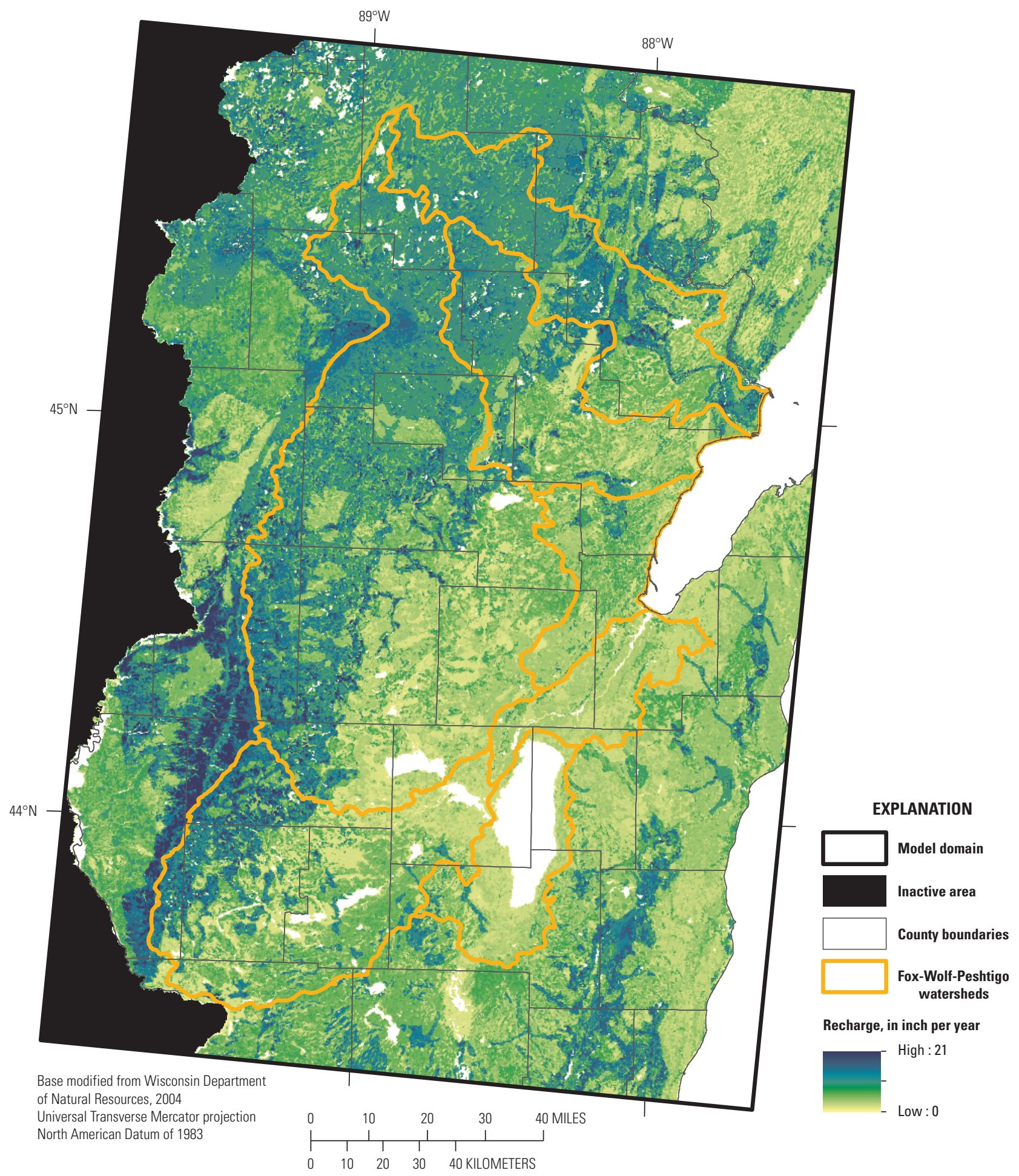

Figure 18. The calibrated recharge pattern for the 5-layer heterogeneous model. 


\section{Calibration Comparison}

Direct comparisons of the model calibrations are best evaluated using only the glacial aquifer system wells and baseflow targets. Summary statistics for water levels in the glacial aquifer are listed in table 18; calibration statistics for baseflow targets are listed in table 19. The 5-layer models included 119 additional glacial well construction report targets for calibration that were removed from the 1-layer model prior to calibration because of evidence of vertical gradients that cannot be simulated with a 1-layer model. Thus, these 119 wells used to calibrate the 5-layer models were ignored for the summary statistics listed in table 18. In addition, four target wells from the USGS NWIS located in the glacial aquifer system were inadvertently assigned to layer 4 (unconfined bedrock) in the 5-layer models during calibration setup because of their well construction information; the four wells were correctly assigned to the glacial system for the 1-layer model. Thus, these four wells used to calibrate the 1-layer model were ignored for the summary statistics listed in table 18. Finally, table 18 does not include water-level targets in layers 4 and 5 for the 5-layer models; therefore, the percent of the total sum of squared-weighted residuals (percent of total PHI) columns in tables 18 and 19 do not sum to 100 percent for the 5-layer models (because of rounding, percent of total PHI sums to 100 for the 1-layer model despite ignoring four wells in table 18).

Summary statistics in table 18 indicate that simulated water levels in the glacial aquifer system generally improve as complexity is added to each model. That is, the mean absolute error, root-mean squared error (RMSE), and PHI all decrease when comparing the 1-layer model to the 5-layer zoned model and also when comparing the 5-layer zoned model to the 5-layer heterogeneous model. Adding heterogeneity to the glacial aquifer system seems to produce a larger improvement in water-level residuals than adding layers. However, direct comparison of the 5-layer zoned model and the 1-layer zoned model is challenged by the fact that multiple factors changed between these models. Some of the factors include the following: (1) dividing the glacial aquifer into 3 layers, (2) adding bedrock layers, (3) including 119 glacial targets that seemed to be affected by vertical gradients, and (4) including water-level targets in the bedrock aquifers. Items 1 and 2 would be expected to provide added detail and realism to improve simulation of water levels in the glacial aquifer system; however, the addition of new targets would logically compete with the original targets used to calibrate the 1-layer model and potentially degrade the match to measured water levels for the 4,400 wells summarized in table 18 . Thus, it is

Table 18. Summary statistics for each model using water-level targets in the glacial aquifer system.

[ft, foot; RMSE, root-mean squared error; PHI, sum of squared-weighted residuals that is minimized by PEST during the calibration process]

\begin{tabular}{lccccccc}
\hline \multicolumn{1}{c}{ Model } & $\begin{array}{c}\text { Number of } \\
\text { water-level } \\
\text { targets in } \\
\text { the glacial } \\
\text { aquifer }\end{array}$ & $\begin{array}{c}\text { Mean } \\
\text { error for } \\
\text { water } \\
\text { levels } \\
\text { (ft) }\end{array}$ & $\begin{array}{c}\text { Mean } \\
\text { absolute } \\
\text { error for } \\
\text { water } \\
\text { levels } \\
\text { (ft) }\end{array}$ & $\begin{array}{c}\text { RMSE } \\
\text { for water } \\
\text { levels } \\
\text { (ft) }\end{array}$ & $\begin{array}{c}\text { Range in } \\
\text { measured } \\
\text { water } \\
\text { levels } \\
\text { (ft) }\end{array}$ & $\begin{array}{c}\text { RMSE/range } \\
\text { Sum of squared } \\
\text { weighted residuals } \\
\text { (PHI in PEST) for } \\
\text { glacial well targets }\end{array}$ & $\begin{array}{c}\text { Total PHI } \\
\text { (percent) }\end{array}$ \\
\hline 1-layer model & 4,400 & 0.18 & 11.8 & 17.6 & 1,158 & 0.015 & 148,992 \\
5-layer zoned model & 4,400 & 1.70 & 11.5 & 17.3 & 1,158 & 0.015 & 134,057 \\
$\begin{array}{l}\text { 5-layer hetero- } \\
\text { geneous model }\end{array}$ & 4,400 & 0.78 & 9.92 & 15.1 & 1,158 & 0.013 & 97,346 \\
\hline
\end{tabular}

Table 19. Summary statistics for each model using all base-flow targets.

[ft ${ }^{3} / \mathrm{s}$, cubic foot per second; RMSE, root-mean squared error; PHI, sum of squared-weighted residuals that is minimized by PEST during the calibration process]

\begin{tabular}{|c|c|c|c|c|c|c|c|c|}
\hline Model & $\begin{array}{l}\text { Number of } \\
\text { base-flow } \\
\text { targets }\end{array}$ & $\begin{array}{c}\text { Mean error } \\
\text { for base } \\
\text { flows } \\
\left(\mathrm{ft}^{3} / \mathrm{s}\right)\end{array}$ & $\begin{array}{c}\text { Mean } \\
\text { absolute } \\
\text { error for } \\
\text { base flows } \\
\left(\mathrm{ft}^{3} / \mathrm{s}\right)\end{array}$ & $\begin{array}{l}\text { RMSE for } \\
\text { base flows } \\
\left(\mathrm{ft}^{3} / \mathbf{s}\right)\end{array}$ & $\begin{array}{c}\text { Range in } \\
\text { measured } \\
\text { base flows } \\
\left(\mathrm{ft}^{3} / \mathbf{s}\right)\end{array}$ & RMSE/range & $\begin{array}{l}\text { Sum of squared weighted } \\
\text { residuals (PHI in PEST) } \\
\text { for base-flow targets }\end{array}$ & $\begin{array}{l}\text { Total PHI } \\
\text { (percent) }\end{array}$ \\
\hline 1-layer model & 200 & 2.8 & 15.8 & 38.6 & 1,460 & 0.026 & 129,269 & 46 \\
\hline $\begin{array}{l}\text { 5-layer zoned } \\
\text { model }\end{array}$ & 200 & 3.5 & 15.6 & 38.7 & 1,460 & 0.026 & 127,794 & 30 \\
\hline
\end{tabular}


difficult to ascertain whether the observed improvement in the summary statistics between the 1-layer and the 5-layer zoned models might have been larger had only the 4,400 targets in table 18 been used to calibrate every model. Regardless, both 5 -layer models performed better for the 4,400 glacial waterlevel targets than the 1-layer model, despite being calibrated to additional targets. Summary statistics for base-flow targets (table 19) indicate modest reductions in the mean absolute error and PHI when comparing the 1-layer model to the 5-layer zoned model and also when comparing the 5-layer zoned model to the 5-layer heterogeneous model. However, the RMSE increased slightly from the 1-layer to the 5-layer zoned model. Thus, results indicate that increasing complexity generally had less effect on overall fit for base-flow targets compared with water-level targets.

Additional insight into the effects of adding complexity on the calibration metrics is facilitated through direct comparison of targets among the models. The change in absolute error for each glacial well and base-flow target, respectively, was compared by subtracting results for the less complex model from the more complex model and summarized in tables 20 and 21. Results listed in table 20 indicate that a larger percent of water-level targets (59 percent) exhibited improvement (lower absolute errors) when heterogeneous hydraulic conductivity was added to the model compared with adding layers (51 percent). In addition, the magnitude of improvement (4.6 feet) and degradation ( 2.9 feet) were larger when heterogeneity was added compared with adding layers to the model (1.9 and 1.3 feet). Thus, results indicate that adding heterogeneity had more effect (larger magnitude) on simulated waterlevel targets, both in terms of improvement and degradation, than adding layers. This result was not surprising given that 119 targets suspected of being affected by vertical gradients were removed from the 1-layer model and, thus, removed from this analysis. The result also was not surprising because additional estimated parameters available to the 5-layer zoned model compared with the 1-layer model were associated with vertical anisotropy and permeability of the bedrock - parameters not expected to have a strong effect on water levels in a largely Dupuit-Forchheimer dominated flow system (little resistance to vertical flow along predominantly horizontal flow paths). Conversely, six additional horizontal hydraulic conductivity parameter values were calibrated for the heterogeneous model. Although any increase in parameter flexibility logically provides greater flexibility with which to match calibration targets, results indicate that this system is largely dominated by horizontal flow; therefore, water-level targets responded more to complexity associated with horizontal hydraulic conductivity than vertical hydraulic conductivity. Comparison of baseflow targets among models of increasing complexity (table 21) is less clear, with a larger percent of base-flow targets indicating improvement because of the addition of layers ( 57 percent) compared with the addition of heterogeneity (51 percent), yet the magnitude of base-flow change was larger when heterogeneity was added compared with the addition of layers.

Identifying where and how additional complexity improved simulated water levels is facilitated by spatially plotting (fig. 19) the change in residuals among models for the 4,400 targets summarized in table 20 . The change in residuals was computed using the absolute error for each target, with reductions or increases in absolute error computed in terms of moving from a simpler model to a more complex model (1-layer to 5-layers; zoned to heterogeneous). Results indicate that using three layers rather than one layer to simulate the glacial aquifer system with the 5-layer zoned model (fig. 19A) produces little change (less than 5 feet of difference) for most targets, which agrees with results in table 20 . Nonetheless, results indicate that the largest improvements were within the loamy till and fine-stratified glacial categories, especially in headwater areas were vertical gradients are expected to be largest. Indeed, many of the 119 targets that were removed from the 1-layer model calibration because of perceived vertical gradients were within the fine-stratified glacial category and likely would have exhibited a similar improvement with the addition of model layers. Most targets in the coarsegrained glacial categories did not seem to be affected by the addition of model layers. These findings generally match with the concepts of the Dupuit-Forchheimer approximations wherein areas that are "recharge controlled" exhibit small vertical gradients and are well approximated with a single

Table 20. Change in absolute error for water-level targets in the glacial aquifer system.

$[\mathrm{ft}$, foot $]$

\begin{tabular}{|c|c|c|c|c|c|}
\hline Models compared & $\begin{array}{c}\text { Number of water-level } \\
\text { targets in the glacial } \\
\text { aquifer }\end{array}$ & $\begin{array}{l}\text { Number of improved } \\
\text { water-level targets in } \\
\text { the glacial aquifer }\end{array}$ & $\begin{array}{l}\text { Improved water-level } \\
\text { targets in the glacial } \\
\text { aquifer (percent) }\end{array}$ & $\begin{array}{l}\text { Average reduction } \\
\text { in absolute error for } \\
\text { improved targets (ft) }\end{array}$ & $\begin{array}{l}\text { Average increase } \\
\text { in absolute error for } \\
\text { degraded targets (ft) }\end{array}$ \\
\hline $\begin{array}{l}\text { 5-layer zoned model } \\
\text { versus 1-layer } \\
\text { model }\end{array}$ & 4,400 & 2,272 & 51 & 1.9 & 1.3 \\
\hline $\begin{array}{l}\text { 5-layer heteroge- } \\
\text { neous model } \\
\text { versus 5-layer } \\
\text { zoned model }\end{array}$ & 4,400 & 2,617 & 59 & 4.6 & 2.9 \\
\hline
\end{tabular}


Table 21. Change in absolute error for base-flow targets.

[ $\mathrm{ft}^{3} / \mathrm{s}$, cubic foot per second]

\begin{tabular}{cccccc}
\hline Model compared & $\begin{array}{c}\text { Number of } \\
\text { base-flow targets }\end{array}$ & $\begin{array}{c}\text { Number of improved } \\
\text { water-level targets in } \\
\text { the glacial aquifer }\end{array}$ & $\begin{array}{c}\text { Improved water-level } \\
\text { targets in the glacial } \\
\text { aquifer } \\
\text { (percent) }\end{array}$ & $\begin{array}{c}\text { Average reduction } \\
\text { in absolute error for } \\
\text { improved targets } \\
\left(\mathbf{f t}^{3} / \mathbf{s}\right)\end{array}$ & $\begin{array}{c}\text { Average increase } \\
\text { in absolute error for } \\
\text { degraded targets } \\
\left(\mathbf{f t}^{3} / \mathbf{s}\right)\end{array}$ \\
\hline $\begin{array}{c}5 \text {-layer zoned model } \\
\text { versus 1-layer } \\
\text { model }\end{array}$ & 200 & 114 & 57 & 1.0 & 0.95 \\
$\begin{array}{c}5 \text {-layer heteroge- } \\
\text { neous model } \\
\text { versus 5-layer } \\
\text { zoned model }\end{array}$ & 200 & 103 & 51 & 3.8 & 3.6 \\
\hline
\end{tabular}

layer, whereas areas that are "topography controlled" exhibit stronger vertical gradients and benefit from additional vertical discretization (Haitjema and Mitchell-Bruker, 2005).

Adding heterogeneity to the 5-layer model seems to have improved the simulated water level (by at least 5 feet) for a greater number of glacial targets (fig. 19B) than just the addition of layers (fig. 19A). The results indicate that the greatest improvements were within the coarse-stratified and sandy till glacial categories, as well as for some wells in the fine-stratified category. This result matches with the sensitivity of the targets to these glacial categories, as noted by the fact that the Min_hk, Exp_hk, and Max_hk parameters were sufficiently sensitive that they could be estimated for all three of these glacial categories for the 5-layer heterogeneous model (table 13), whereas the Min_hk and Max_hk parameters for other glacial categories were not sufficiently sensitive to be independently estimated given the calibration targets. These three glacial categories cover most of the model domain, indicating that heterogeneity may be an important factor in controlling local water levels within much of the FWP study area. Improvements among base-flow targets were generally similar to water-level targets, with a greater magnitude of change observed when heterogeneity was added compared with just the addition of layers (table 21). However, the improvements were smaller than for water-level targets, and spatial inferences of the causes are complicated by the large accumulating areas that affect base-flow targets; therefore, for the sake of brevity, maps of improved base-flow residuals are not shown.

The extent to which transferability of insights into how water levels and base flows respond to differing forms of model complexity remains unclear for other modeling objectives. Few models are designed with their sole objective to produce the best possible calibration to water-level and base-flow targets; commonly the objectives are of a different type than the calibration dataset. Simmons and Hunt (2012) provided a short summary of previous discussions related to model complexity, with the concluding point being that "the model objective becomes the primary prism for any and all discussions of model complexity." The goals of this study ultimately revolve around simulating groundwater ages.
Continued applications of the models described in this report are anticipated to inform larger NAWQA goals related to adequate representation of model complexity for estimating groundwater ages at regional aquifer scales.

\section{Limitations of the Groundwater-Flow Models}

As is the case with all models, the groundwater-flow models described in this report are simplifications of the physical system and have corresponding limitations in model accuracy and how the models should be used. For example, the model-calibration process focused on steady-state waterlevel and base-flow targets to estimate hydrologic and hydrogeologic properties. As a result, the model cannot reliably simulate seasonal water-level fluctuations. In addition, because of the model cell discretization ( 1,000 -foot-wide cells) the conditions within each cell (for example, the groundwater level) are reduced to one mean value for the cell. Although this cell size is expected to be adequate for the simulation objectives described in this report, new analyses requiring finer spatial detail would benefit from refinement of the model. Also, the model may not perform equally well in all locations because of local geologic complexities that were not incorporated into the model; that is, the calibrated hydraulicconductivity fields of the 5-layer heterogeneous model were designed to incorporate heterogeneity as a function of coarse fraction described in lithologic logs. Where local lithologic logs lack sufficient accuracy or density, additional heterogeneity may exist at the local scale. Moreover, this method lumps distant areas into glacial categories based on mapped extents of broad lithologic descriptions; for areas in which this association is a poor match, the calibrated parameters may provide poor representation of the local geology. Similarly, the regional design and calibration of the model further limits the local-scale accuracy of model parameters and model results. That is, reference to parameter values used in these models, 
$\boldsymbol{A}$

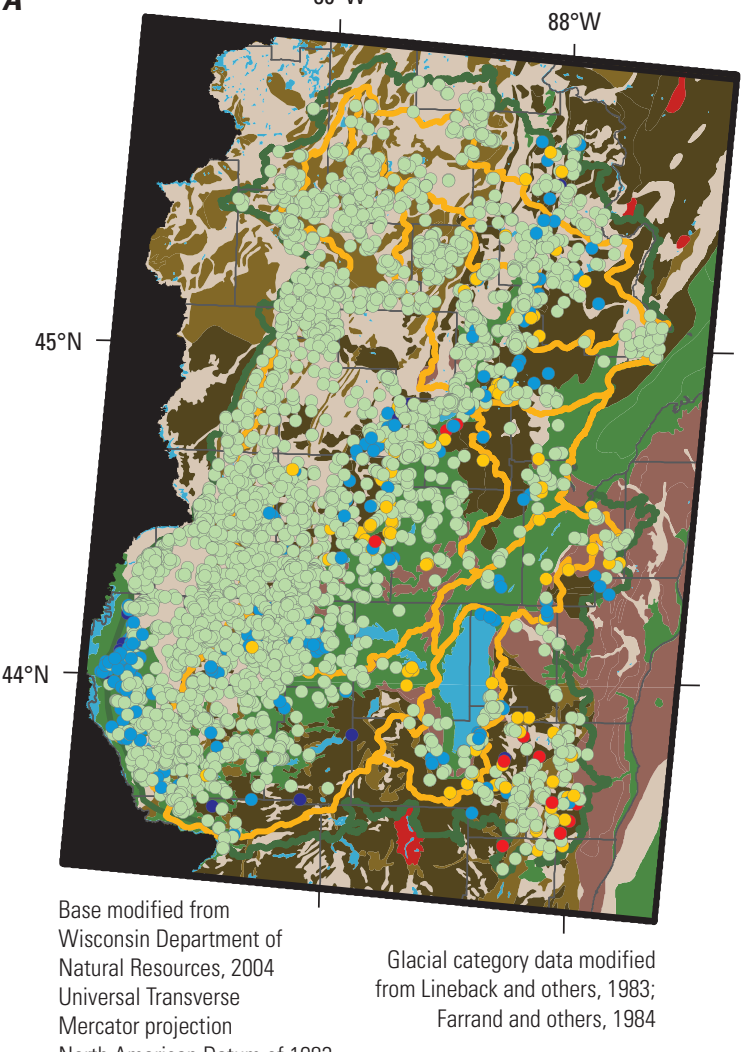

B

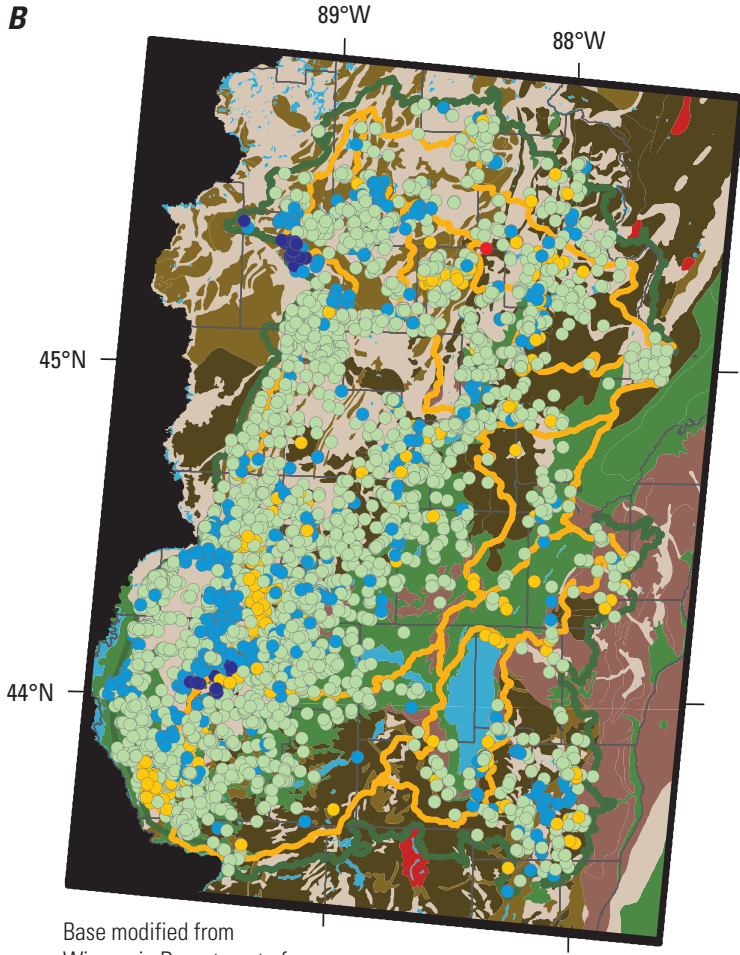

Wisconsin Department of

Natural Resources, 2004

Universal Transverse

Mercator projection

Glacial category data modified from Lineback and others, 1983 Farrand and others, 1984

North American Datum of 1983

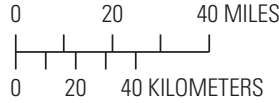

\section{EXPLANATION}

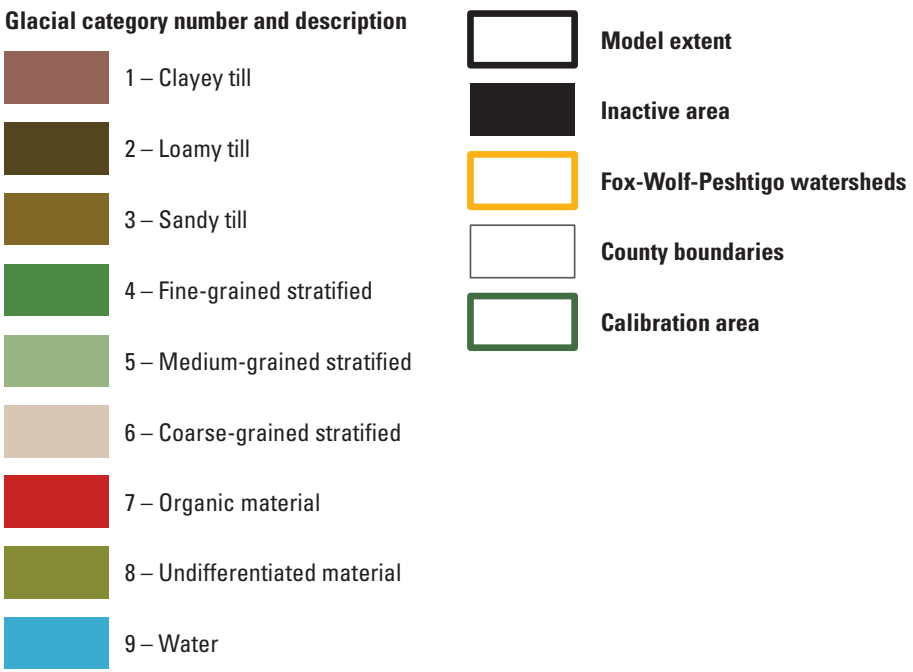

5-layer heterogeneous compared to 5-layer zoned

- Greater than 25-foot reduction in absolute error

- 5- to 25-foot reduction in absolute error

Less than 5-foot change in absolute error

- 5- to 25-foot increase in absolute error

- Greater than 25-foot increase in absolute error

Figure 19. Change in water-level target residuals between $A$, the 5 -layer zoned model and the 1 -layer model and $B$, the 5 -layer heterogeneous model and the 5 -layer zoned model. 
such has hydraulic conductivity and recharge, should focus on regional or zone-based averages rather than local extremes.

The objective of this suite of models was to provide a foundation for future analysis of groundwater age distributions in the glacial aquifer system and to evaluate some effects of complexity on simulated water levels. Application of these models for other purposes, such as to evaluate the effect of a proposed groundwater withdrawal on surface-water features, may be of limited value and would benefit from further evaluation of the calibration parameters, grid resolution and surface-water conductance parameters, which affect groundwater/ surface-water interactions. Similarly, problems focused on evaluating effects of groundwater withdrawal on surface-water features may benefit from simulating specific water bodies of interest with more advanced packages, such as the Lake Package (Merritt and Konikow, 2000). This work also focused on the glacial aquifer system and greatly simplified the bedrock aquifers; interested readers are referred to other resources, such as models produced by Feinstein and others (2010) as a starting point for evaluating groundwater in the bedrock aquifers. In addition, potential applications of the models for which groundwater-flow velocities are important (for example, mapping time-referenced contributing areas to wells, such as a "10-year area contributing recharge to a well") would likely benefit from evaluation of porosities and groundwater age tracer concentrations. Local grid refinement or the use of an unstructured grid (Panday and others, 2013) may be warranted for simulations that require greater precision for computing the curvilinear path of tracked groundwater flow particles or their associated particle travel times.

Finally, this study did not consider effects of parameter uncertainty when comparing differing levels of model complexity. That is, the model calibration process often results in non-unique parameters, such that multiple sets of parameters could produce similar calibration metrics. Linear and nonlinear tools are available with PEST (Doherty, 2010) for evaluating effects of this uncertainty on simulated results. Such uncertainty analyses were beyond the scope of the work described in this report, but could be evaluated in the future. Ideally, the appropriate level of model complexity would be evaluated in terms of the models' ability to simulate a specific prediction or scenario of interest. For the suite of models described in this report, that prediction is anticipated to be a future comparison of simulated and measured age tracer concentrations.

\section{Summary and Conclusions}

The U.S. Geological Survey National Water-Quality Assessment is tasked with estimating the intrinsic susceptibility of the glacial aquifer system in the conterminous United States. As part of this effort, better understanding is needed of factors controlling groundwater travel times, or age, from the land surface to domestic and community supply wells and to streams. The three groundwater-flow models of the Fox-Wolf-Peshtigo study area in northeastern Wisconsin were constructed to provide a framework for future evaluations of differing levels of complexity on simulated groundwater age distributions. This report describes the construction and calibration of these models, and an evaluation of the effects of differing levels of complexity on the calibration metrics. The three models included a 1-layer zoned hydraulic conductivity model representing only glacial aquifer deposits, a 5-layer zoned hydraulic conductivity model with three layers representing the glacial aquifer and two layers representing bedrock aquifers, and a 5-layer heterogeneous hydraulic conductivity model with heterogeneity applied to the three glacial layers through an algorithm that incorporated mapped glacial deposits and lithologic logs.

Notable outcomes from the modeling work include the following:

Development and application of a tool for adjusting the bedrock surface beneath glacial deposits, such that a published 1-kilometer resolution grid of the bedrock surface was locally updated to account for discrepancies at lithologic logs obtained from widely available well construction reports filed by well drillers.

Development and application of a tool for computing heterogeneous hydraulic conductivity fields using mapped glacial deposits and lithologic logs from well construction reports.

For the models described in this report, a simplified version of the Quaternary Atlas was used to produce mapped glacial categories, within which hydraulic conductivity was computed as a function of the coarse fraction (percent of lithologic descriptions indicative of coarse-grained material) from a standardized lithologic database of well construction reports. The tool includes a flexible input structure that was used to calibrate estimates of the minimum, expected, and maximum hydraulic conductivity on a cell-by-cell basis, as associated with the minimum, mean, and maximum coarse fractions within the corresponding glacial categories.

All three models were built on the same updated bedrock surface and glacial categories, were calibrated to similar datasets, and then were compared with each other to evaluate the effect of increasing model complexity on simulated heads and flows in the glacial aquifer system. The 5-layer models used three layers to represent the glacial deposits, which represented advancement compared with the 1-layer model, and allowed for simulation of vertical gradients within the glacial system. The 5-layer models also incorporated one unconfined and one confined bedrock layer from an "intermediate" model of the Lake Michigan Basin. The three models were calibrated to 200 base-flow targets and 4,404 to 9,049 water-levels targets. Targets for the 1-layer model were limited to glacial wells with minimal perceived effect from vertical gradients; targets for the 5-layer models included all glacial wells plus bedrock wells.

Comparisons of glacial target wells indicate improved simulation of water levels in the glacial aquifer system with each increase in model complexity-from the 1-layer model, 
to the 5-layer zoned hydraulic conductivity model, to the 5-layer heterogeneous hydraulic conductivity model. Simulating the glacial aquifer system with multiple layers seems to have improved water levels the most within loamy till and fine-stratified material, especially near headwater areas where vertical gradients would be expected. Adding heterogeneity to the glacial aquifer system seems to have improved simulated water levels predominately in coarse-stratified, sandy till, and fine-stratified deposits where targets contained enough information to allow for independent estimation of all three hydraulic conductivity parameters (minimum, expected, and maximum) within each glacial category.

The models described in this report were ultimately designed to evaluate how differing levels of complexity (layering and heterogeneity) affect simulated ages and secondarily to train metamodels of groundwater age across the glacial aquifer system. Thus, subsequent evaluations using particle tracking are needed to assess if layering and heterogeneity across most of the study area similarly improves simulated age distributions. This information provides an important reminder about the transferability of the results described earlier-that evaluation of the appropriate level of model complexity is best viewed in terms of the primary modeling objectives. The goal of this report was to document the models, start the model complexity evaluation, and provide a foundation for the subsequent age analyses.

\section{Acknowledgments}

\section{Technical Support for the Construction and Calibration of the Models}

Michael N. Fienen, Research Hydrologist, U.S. Geological Survey, Middleton, Wisconsin.

Leon Kauffman, Research Hydrologist, U.S. Geological Survey, Lawrenceville, New Jersey.

Jeffery J. Starn, Research Hydrologist, U.S. Geological Survey, East Hartford, Connecticut.

Steve M. Westenbroek, Hydrologist, U.S. Geological Survey, Middleton, Wisconsin.

\section{Publishing Support}

Michelle Greenwood, Reports Specialist, U.S. Geological Survey, Middleton, Wis.

Suzanne Roberts, Visual Information Specialist, U.S. Geological Survey, Cheyenne, Wyoming

\section{Technical Reviewers}

Jason Roth, Hydrologist, U.S. Geological Survey, Mounds View, Minnesota.

Jeff Raffensperger, Hydrologist, U.S. Geological Survey, Baltimore, Maryland.

\section{Editor}

Valerie Dressler, Technical Writer/Editor, U.S. Geological Survey, Bismarck, North Dakota.

\section{Groundwater Specialist Reviewer}

Rodney Sheets, Groundwater Specialist, U.S. Geological Survey, Columbus, Ohio.

\section{Approving Official}

Kevin Breen, Bureau Approving Official, U.S. Geological Survey Office of Science Quality and Integrity, New Cumberland, Pennsylvania.

\section{References Cited}

Abrams, D., Haitjema, H., and Kauffman, L., 2013, On modeling weak sinks in MODPATH: Groundwater, v. 51, no. 4, p. 597-602; doi: 10.1111/j.1745-6584.2012.00995.x.

Allen, R.G., Pereira, L.S., Raes, D., Smith, M., 1998, Crop evapotranspiration-Guidelines for computing crop water requirements: Rome, Italy, Food and Agriculture Organization of the United Nations, FAO Irrigation and Drainage Paper No. 56, 174 p., accessed November 25, 2016, at http://www.kimberly.uidaho.edu/water/fao56/fao56.pdf.

Anderson, M.P., and Woessner, W.W., 1992, Applied groundwater modeling: San Diego, Calif., Academic Press, 381 p.

Anderson, M.P., Woessner, W.W., and Hunt, R.J., 2015, Applied groundwater modeling (2d ed.): San Diego, Calif., Academic Press, 564 p.

Arihood, L.D., 2009, Processing, analysis, and general evaluation of well-driller records for estimating hydrogeologic parameters of the glacial sediments in a ground-water flow model of the Lake Michigan Basin: U.S. Geological Survey Scientific Investigations Report 2008-5184, 26 p. 
Bartošová, Alena, McConkey, Sally, Lin, Yu-Feng, and Walker, Douglas, 2004, Using NHD to estimate stream geometry characteristics for MODFLOW, in American Water Resources Association Spring Specialty Conference, Nashville, Tenn., May 17-19, 2004: Nashville, Tenn., Geographic Information Systems and Water Resources III, 7 p.

Bayless, E.R., Arihood, L.D., Reeves, H.W., Sperl, B.J.S., Qi, S.L., Stipe, V.E., and Bunch, A.R., 2017, Maps of hydrogeologic information created from standardized water-well drillers' records of the glaciated United States: U.S. Geological Survey Scientific Investigations Report 2015-5105, 34 p., https://doi.org/10.3133/sir20155105.

Bradbury, K.R., Fienen, M.N., Kniffin, M., Krause, J., Westenbroek, S.M., Leaf, A.T., and Barlow, P.M., in press, Groundwater flow model for the Little Plover River Basin in Wisconsin's Central Sands: Wisconsin Geological and Natural History Survey Bulletin.

Conlon, T.D., 1998. Hydrogeology and simulation of groundwater flow in the Sandstone Aquifer, northeastern Wisconsin: U.S. Geological Survey Water-Resources Investigations Report 97-4096, 60 p.

Davis, J.C., 1986, Statistics and data analysis in geology ( $2 \mathrm{~d}$ ed.): New York, John Wiley, 646 p.

Dempster, G.R., Jr., comp., 1990, National water information system user's manual, Volume 2, Chapter 3-Automated data processing system: U.S. Geological Survey Open-File Report 90-116 [variously paged], accessed November 25, 2016 at https://pubs.er.usgs.gov/publication/ofr90116.

Doherty, J., 2010, PEST - Model-independent parameter estimation user manual (5th ed.), and addendum: Brisbane, Queensland, Australia, Watermark Numerical Computing.

Doherty, J., 2015, Calibration and uncertainty analysis for complex environmental models: Brisbane, Queensland, Australia, Watermark Numerical Computing, 227 p.

Doherty, J., and Hunt, R.J., 2010, Approaches to highly parameterized inversion-A guide to using PEST for groundwater-model calibration: U.S. Geological Survey Scientific Investigations Report 2010-5169, 59 p.

Eberts, S.M., Thomas, M.A., and Jagucki, M.L., 2013, The quality of our Nation's waters-Factors affecting publicsupply-well vulnerability to contamination-Understanding observed water quality and anticipating future water quality: U.S. Geological Survey Circular 1385, 120 p.

Epstein, E.J., Judziewicz, E.J., and Spencer, E.A., 2002, Wisconsin Natural Community Abstracts: Wisconsin Department of Natural Resources, Bureau of Endangered Resources, 16 p., accessed November 25, 2016 at http://dnr. wi.gov/topic/endangeredresources/documents/communities. pdf.
Farrand, W.R., Mickelson, D.M., Cowan, W.R., Goebel, J.E., Richmond, G.M., and Fullerton, D.S., 1984, Quaternary geologic map of the Lake Superior 4 degrees x 6 degrees quadrangle, United States and Canada: U.S. Geological Survey Miscellaneous Investigations Series Map I-1420(NL-16), accessed November 25, 2016 at https:// pubs.er.usgs.gov/publication/i1420(NL16).

Faunt, C.C., Belitz, K., and Hanson, R.T., 2010, Development of a three-dimensional model of sedimentary texture in valley-fill deposits of Central Valley, California, USA: Hydrogeology Journal, v. 18, p. 625-649, accessed November 25, 2016, at http://ca.water.usgs.gov/projects/centralvalley/HydrogeologyJournal-2010-18.pdf.

Feinstein, D.T., Fienen, M.N., Kennedy, J.L., Buchwald, C.A., and Greenwood, M.M., 2012, Development and application of a groundwater/surface-water flow model using MODFLOW-NWT for the Upper Fox River Basin, southeastern Wisconsin: U.S. Geological Survey Scientific Investigations Report 2012-5108, 124 p.

Feinstein, D.T., Fienen, M.N., Reeves, H.W., and Langevin, C.D., 2016, A semi-structured MODFLOW-USG model to evaluate local water sources to wells for decision support: Groundwater, v., 54, no. 4, p. 532-544, doi:10.1111/ gwat.1238., accessed November 25, 2016, at http://onlinelibrary.wiley.com/doi/10.1111/gwat.12389/abstract.

Feinstein, D.T., Hunt, R.J., and Reeves, H.W., 2010, Regional groundwater-flow model of the Lake Michigan Basin in support of Great Lakes Basin water availability and use studies: U.S. Geological Survey Scientific Investigations Report 2010-5109, 379 p.

Fienen, M.N., Nolan, B.T., Feinstein, D.T., and Starn, J.J., 2015, Metamodels to bridge the gap between modeling and decision support: Groundwater, v. 53, no. 4, p. 511-512.

Gebert, W.A., Walker, J.F., and Kennedy, J.L., 2011, Estimating 1970-99 average annual recharge in Wisconsin using streamflow data: U.S. Geological Survey Open-File Report 2009-1210, 14 p., plus appendixes.

Haitjema, H.M., and Mitchell-Bruker, S.M., 2005, Are water tables a subdued replica of the topography?: Groundwater, v. 43 , no. 6 , p. $781-786$, accessed November 25,2016 , at http://onlinelibrary.wiley.com/doi/10.1111/j.17456584.2005.00090.x/full.

Harbaugh, A.W., 2005, MODFLOW-2005-The U.S. Geological Survey modular ground-water model-The groundwater flow process: U.S. Geological Survey Techniques and Methods, book 6, chap. A16 [variously paged]. 
Harbaugh, A.W., Banta, E.R., Hill, M.C., and McDonald, M.G., 2000, MODFLOW-2000-The U.S. Geological Survey modular ground-water model-User guide to modularization concepts and the ground-water flow process: U.S. Geological Survey Open-File Report 2000-92, 121 p.

Homer, C.G., Dewitz, J.A., Yang, L., Jin, S., Danielson, P., Xian, G., Coulston, J., Herold, N.D., Wickham, J.D., and Megown, K., 2015, Completion of the 2011 National Land Cover Database for the conterminous United States-Representing a decade of land cover change information. Photogrammetric Engineering and Remote Sensing, v. 81, no. 5, p. 345-354.

Institute of Hydrology, 1980a, Low flow studies- Report no. 1: Wallingford, Oxon, United Kingdom, 41 p.

Institute of Hydrology, 1980b, Low flow studies-Report no. 3: Wallingford, Oxon, United Kingdom, p. 12-19.

Jones, E., Oliphant, E., Peterson, P., and others, 2001-16, Scipy-Open Source Scientific Tools for Python: accessed May 13, 2016, at http://www.scipy.org.

Juckem, P.F., and Dunning, C.P., 2015, Simulation of the regional groundwater-flow system of the Menominee Indian Reservation, Wisconsin. U.S. Geological Survey Scientific Investigations Report 2014-5237, 40 p., 1 appendix.

Kammerer, P.A., Trotta, L.C., Krabbenhoft, D.P., and Lidwin, R.A., 1998, Geology, ground-water flow, and dissolved-solids concentrations in ground water along hydrogeologic sections through Wisconsin aquifers: U.S. Geological Survey Hydrologic Investigations Atlas HA-731, 4 sheets.

Kitanidis, P.K., 1997, Introduction to Geostatistics-Applications in hydrogeology: Cambridge, United Kingdom, Cambridge University Press, 249 p.

Konikow, L.F., Hornberger, G.Z., Halford, K.J., and Hanson, R.T., 2009, Revised multi-node well (MNW2) package for MODFLOW ground-water flow model: U.S. Geological Survey Techniques and Methods book 6, chap. A30, 67 p.

Kozuskanich, J., Simmons, C.T., Cook, P.G., 2014, Estimating recharge rate from groundwater age using a simplified analytical approach-Applicability and error estimation in heterogeneous porous media: Journal of Hydrology, v. 511, p. 290-294, accessed November 25, 2016, at http://dx.doi. org/10.1016/j.jhydrol.2014.01.058.

Kraft, G.J., and Mechenich, D.J., 2010, Groundwater pumping effects on groundwater levels, lake levels, and streamflows in the Wisconsin central sands-A Report to the Wisconsin Department of Natural Resources in completion of project NMI00000247, 67 p., accessed May 25, 2016, at http:// www.uwsp.edu/cnr-ap/watershed/Documents/gwpumpcentralsands2010.pdf.
Krohelski, J.T., 1986, Hydrogeology and ground-water use and quality, Brown County, Wisconsin: Wisconsin Geological and Natural History Survey Information Circular 57, $42 \mathrm{p}$.

Lineback, J.A., Bleuer, N.K., Mickelson, D.M., Ferrand, W.R., Goldthwait, R.P., Richmond, G.M., and Fullerton, D.S., 1983, Quaternary geologic map of the Chicago 4 degrees x 6 degrees quadrangle, United States. U.S. Geological Survey Miscellaneous Investigations Series Map I-1420(NK-16).

Luther, K.H., and Haitjema, H.M., 1998, Numerical experiments on the residence time distributions of heterogeneous groundwatersheds: Journal of Hydrology, v. 207, p. 1-17.

Mathey, S.B., ed., 1989, National water information system user's manual, v. 2, chap. 4, Ground-Water Site Inventory System: U.S. Geological Survey Open-File Report 89-587, $281 \mathrm{p}$.

McDonald, M.G., and Harbaugh, A.W., 1988, A modular three-dimensional finite-difference ground-water flow model: U.S. Geological Survey Techniques of WaterResources Investigations, book 6, chap. A1, 586 p.

McKay, L., Bondelid, T., Dewald, T., Johnston, J., Moore, R., and Rea, A., 2012, "NHDPlus Version 2-User Guide": U.S. Environmental Protection Agency, 182 p.

Merritt, M.L., and Konikow, L.F., 2000, Documentation of a computer program to simulate lake-aquifer interaction using the MODFLOW ground-water flow model and the MOC3D solute-transport model: U.S. Geological Survey WaterResources Investigations Report 00-4167, 146 p.

Mossler, J.H., 1992, Sedimentary rocks of Dresbachian age (lake Cambrian), Hollendale Embayment, southeastern Minnesota: Minnesota Geological Survey Report of Investigations $40,71 \mathrm{p}$.

Niswonger, R.G., Panday, S., and Ibaraki, M., 2011, MODFLOW-NWT, A Newton formulation for MODFLOW-2005: U.S. Geological Survey Techniques and Methods book 6, chap. A37, 44 p.

Niswonger, R.G., and Prudic, D.E., 2005, Documentation of the Streamflow-Routing (SFR2) Package to include unsaturated flow beneath streams-A modification to SFR1: U.S. Geological Survey Techniques and Methods, book 6, chap. A13, 50 p.

Niswonger, R.G., Prudic, D.E., and Regan, R.S., 2006, Documentation of the Unsaturated-Zone Flow (UZF1) Package for modeling unsaturated flow between the land surface and the water table with MODFLOW-2005: U.S. Geological Survey Techniques and Methods, book 6, chap A19, 62 p. 
Panday, S., Langevin, C.D., Niswonger, R.G., Ibaraki, M., and Hughes, J.D., 2013, MODFLOW-USG version 1-An unstructured grid version of MODFLOW for simulating groundwater flow and tightly coupled processes using a control volume finite-difference formulation: U.S. Geological Survey Techniques and Methods, book 6, chap. A45, $66 \mathrm{p}$.

Prudic, D.E., Konikow, L.F., and Banta, E.R., 2004, A new Streamflow-Routing (SFR1) Package to simulate streamaquifer interaction with MODFLOW-2000: U.S. Geological Survey Open-File Report 2004-1042, 35 p.

Saad, D.A., 1997, Effects of landuse and geohydrology of the quality of shallow ground water in two agricultural areas in the western Lake Michigan drainages, Wisconsin: U.S. Geological Survey Water-Resources Investigations Report 96-4292, $69 \mathrm{p}$.

Saad, D.A., 2008, Agriculture-related trends in groundwater quality of the glacial deposits aquifer, central Wisconsin: Journal of Environmental Quality, v. 37, no. 5 (supplemental), p. S-209-S-225.

Saad, D.A., and Thorstenson, D.C., 1998, Flow and geochemistry along shallow ground-water flowpaths in an agricultural area in southeastern Wisconsin: U.S. Geological Survey Water-Resources Investigations Report 98-4179, 62 p.

Simmons, D.T., and Hunt, R.J., 2012, Updating the debate on model complexity: GSA Today, v. 22, no. 8, p. 28-29, accessed November 25, 2016, at http://dx.doi.org/10.1130/ GSATG150GW.1.

Soil Survey Staff, 2014, Gridded soil survey geographic (gSSURGO) database for Wisconsin: United States Department of Agriculture, Natural Resources Conservation Service, accessed November 25, 2016 at https://gdg.sc.egov. usda.gov.

Soller, D.R., Packard, P.H., and Garrity, C.P., 2012, Database for USGS Map I-1970 - Map showing the thickness and character of Quaternary sediments in the glaciated United States east of the Rocky Mountains: U.S. Geological Survey Data Series 656, accessed November 25, 2016, at https:// pubs.usgs.gov/ds/656/.

Tesoriero, A.J., Duff, J.H., Saad, D.A., Spahr, N.E., and Wolock, D.M, 2013, Vulnerability of streams to legacy nitrate sources: Environmental Science and Technology, v. 47, p. 3623-3629, accessed November 25, 2016, at http:// dx.doi.org/10.1021/es305026x.
Thornthwaite, C.W., and Mather, J.R., 1957, Instructions and tables for computing potential evapotranspiration and the water balance: Centerton, N. J., Laboratory of Climatology, Publications in Climatology, v. 10, no. 3, p. 185-311.

Thornton, P.E., Thornton, M.M., Mayer, B.W., Wilhelmi, N., Wei, Y., Devarakonda, R., and Cook, R.B., 2014, Daymet: Daily Surface Weather Data on a 1-km Grid for North America, Version 2: accessed: May 16, 2016, at http:// dx.doi.org/10.3334/ORNLDAAC/1219.

U.S. Department of Agriculture, 1986, Urban hydrology for small watersheds: Technical Release 55 (TR-55, 2d ed.), Natural Resources Conservation Service, Conservation Engineering Division, 103 p., 6 appendices.

U.S. Geological Survey, 2014, National Elevation Dataset (NED) $1 / 3$ arc-second-Downloadable data collection, accessed November 25, 2016, at https://www.sciencebase. gov/catalog/item/4f70aa9fe4b058caae3f8de5.

U.S. Geological Survey, 2016, User's manual for the national water information system of the U.S. Geological SurveyGround-Water Site-Inventory System, version 5.2, accessed September 22, 2016, at https://nwis.usgs.gov/currentdocs/ gw/GW.user.book.html.

Vogel, J.C., 1967, Investigation of groundwater flow with radiocarbon, in Isotopes in Hydrology, Vienna, Austria, November 14-18, 1966, Proceedings: Vienna, Austria, International Atomic Energy Agency, p. 355-369.

Wahl, K.L., and Wahl, T.L., 1995, Determining the flow of Comal Springs at Braunfels, Texas, in Texas Water '95, San Antonio, Tex., August 16-17, 1995, Proceedings: San Antonio, Tex., American Society of Civil Engineers, p. 77-86.

Westenbroek, S.M., Kelson, V.A., Dripps, W.R., Hunt, R.J., and Bradbury, K.R., 2010, SWB-A modified Thornthwaite-Mather Soil-Water-Balance code for estimating groundwater recharge: U.S. Geological Survey Techniques and Methods book 6, chap. A31, $60 \mathrm{p}$.

Wisconsin Department of Natural Resources, 2001, Locational data standards - Version 1.1, 42 p., plus appendixes, accessed May 19, 2016, at http://dnr.wi.gov/maps/gis/documents/loc_data_std.pdf.

Wisconsin Department of Natural Resources, 2014, Water well data files: CD-ROM. 
Publishing support provided by:

Madison and Rolla Publishing Service Centers

For additional information concerning this publication, contact: Director, USGS Wisconsin Water Science Center

8505 Research Way

Middleton, WI 53562

(608) 828-9901

Or visit the Wisconsin Water Science Center Web site at: https://wi.water.usgs.gov 
